\title{
MONETARY POLICY: EFFECTIVENESS, EFFICIENCY, RISK, AND PERSPECTIVES
}

\author{
Dr. IOANNIS N. KALLIANIOTIS \\ Economics/Finance Department \\ The Arthur J. Kania School of Management \\ University of Scranton \\ Scranton, PA 18510-4602 \\ Tel. (570) 941-7577 \\ Fax (570) 941-4825
}

https://doi.org/10.37602/IJSSMR.2021.4405

\begin{abstract}
In this paper it is discussed the latest monetary policy and the new instruments and innovations that the Fed introduced after 2008 and 2020 and we examine their effectiveness, efficiency, and prospective risk. The first major Fed's changes were on December 20, 2008 by altering the fed funds market in a number of different ways: (1) zero fed funds rate ( $i \mathrm{FF}=$ $0.00 \%$ ), (2) the Fed started paying interest on reserves (IOR) held by or on behalf of depository institutions at Reserve Banks, subject to regulations of the Board of Governors, effective October 1, 2011 and interest on the overnight reverse repurchase agreement (ON RRP) in 2014, and (3) the Fed abolished the required reserves by making them since March 26,2020 zero. The effectiveness of this policy is unspecified, due to the global financial crisis and the recent suspicious COVID-19 pandemic. The social cost is very high with these "innovated" policies. It seems that the central bank is working for the banks and satisfies only their objectives, which are profitability and liquidity. This monetary policy is against depositors (bail in cost) and against taxpayers (bail out cost); so, it is an unfair public policy, an anti-social monetary policy and at the same time it has created enormous bubbles in the stock market, which can lead us to a new global financial crisis, after the global health crisis, and to a high true inflation. The social benefits are relatively small on consumption, investment, financial markets, trade, growth, employment, and consequently, on social welfare because the economy is in a lockdown for almost two years and in an ineffective (prejudiced) fiscal stimulus, which preserves unemployment and increases public and private debts by discouraging work and production. Thus, this monetary policy is not effective and not efficient; and it may be proved to be very risky, too. These last two crises in 2008 and in 2020 need a combination of public policies and cooperation among the different policy makers and a strong impartial government. The latest monetary policy combined with the loss of self-sufficiency, the outsourcing, the unfair international trade, the unlawful competition from Asia, and the current divisions (unorthodox liberalism, cancel culture, control over information, invasion of privacy, critical race theory, students indoctrination, "domestic terrorism", etc.) inside the country are generating many challenges and risks for the future, which reduce the social perspective of the citizens of country.
\end{abstract}




\section{International Journal of Social Sciences and Management Review}

Volume: 04, Issue: 04 "July - August 2021"

ISSN 2582-0176

Keywords: Monetary Policy, Central Banks and Their Policies, Money and Interest Rates, Financial Markets and the Macro-economy, Production, Social Welfare

JEL (Classification): E52, E58, E4, E44, E23, D6

\subsection{INTRODUCTION}

Central banks, as all the institutions and international organizations, have very curious history, eccentric march, and mysticism in their hidden "social" objectives. In the U.S., the central bank, the Federal Reserve System (Fed)1 was created by the Federal Reserve Act of 1913,2 which is intended to serve as a formal "lender of last resort" to banks in times of liquidity crises and panics, when depositors try to withdraw their money faster than a bank could pay it out, as it happened many times in 19th century.3 Its public policy, the monetary policy has passed many different phases, revisions, and "improvements" since Fed's creation in 1913.4 This Act brought all banks in the United States under the authority of the Federal Reserve (a "quasi-governmental entity", actually a private bank), which is supervised by the Federal Reserve Board.5 Then, the roles of the Fed are given by the Federal Reserve Act and they are: (1) Market (Financial Market) Stabilization, (2) Control of Money Supply, (3) Lender of Last Resort, (4) Supervisor of the Banking System, and (5) Maintaining and Improving the Payment Mechanism.6

The monetary authority with its monetary policy controls either the interest rate (federal funds rate) payable for overnight or very short-term borrowing (borrowing by banks from each other to meet their short-term needs, the federal funds market) or the money supply (borrowing or non-borrowing reserves). These intermediate targets (iFF and Ms) are used often as an attempt to reduce inflation or to contribute to maximum employment (since 1977), the dual mandate 7 or to control the interest rate, to ensure price stability and general trust of the value and stability of the nation's currency. Also, to generate a stable real

\footnotetext{
${ }^{1}$ See, The Federal Reserve System

${ }^{2}$ See, The Federal Reserve Act of 1913. Also, see, "Federal Reserve Act", https://www.federalreserve.gov/aboutthefed/fract.htm

${ }^{3}$ Between 1863 and 1913, eight banking panics occurred in the money center of Manhattan. The panics in 1884, 1890, 1899, 1901, and 1908 were confined to New York and nearby cities and states. The panics in 1873, 1893, and 1907 spread throughout the nation. Regional panics also struck the mid-western states of Illinois, Minnesota, and Wisconsin in 1896; the mid-Atlantic states of Pennsylvania and Maryland in 1903; and Chicago in 1905. These crises disrupted or threatened to disrupt the national banking and payments system. The Panic of $\underline{1907}$, was the shock that spurred financial and political leaders to consider reforming the monetary system and eventually establish the Federal Reserve. See, "Banking Panics of the Gilded Age",

https://www.federalreservehistory.org/essays/banking-panics-of-the-gilded-age

${ }^{4}$ See, Kallianiotis (2017a ). Also,

https://en.wikipedia.org/wiki/History_of_monetary_policy_in_the_United_States . Further,

https://www.federalreserveeducation.org/about-the-fed/history . Furthermore,

https://www.federalreserve.gov/monetarypolicy/historical-approaches-to-monetary-policy.htm . In addition, https://www.clevelandfed.org/en/newsroom-and-events/speeches/sp-20140327-the-federal-reserve-policyapproaches-then-and-now.aspx . And even more, https://www.frbsf.org/education/teacher-resources/what-is-thefed/history/

${ }^{5}$ See, The Federal Reserve Board..

${ }^{6}$ See, Kallianiotis (2017a).

${ }^{7}$ See, "The Federal Reserve's Dual Mandate". https://www.chicagofed.org/research/dual-mandate/dual-mandate
} 


\section{International Journal of Social Sciences and Management Review}

economic growth (to smooth the business cycle and offset economic shocks), a moderate long-term interest rate, an equilibrium in the current account, and a stability for our financial market.

The central bank (Fed) targets the federal funds rate $\left({ }^{i}{ }_{F F}\right)$ and with this intermediate target rate, it influences all interest rates by expanding or contracting the monetary base (MB), which consists of currency $(\mathrm{C})$ in circulation and banks' reserves $(\mathrm{R})$ at the central bank, eq. (1), Figure 1. The primary tools of monetary policy that the central bank was using to affect the monetary base were open market operations (OMO), which are sales (OMS) and purchases (OMP) of government debt and mortgage-back securities in the open market. Also, by changing the reserve requirements $\left(R_{R}\right), 8$ actually, the reserve requirements ratio $\left({ }_{R}\right)$, the discount rate $\left({ }^{i_{D R}}\right)$, and the margin requirements $\left({ }^{r_{m}}\right)$. If the central bank wishes to lower interest rates, it purchases government debt, thereby increasing the amount of cash in circulation or crediting banks' reserves. The supply of reserves goes from R1s to R2s, Figure 2.

\begin{tabular}{l|l} 
Assets & \multicolumn{1}{c}{ Liabilities } \\
\hline$G C$ & $C$ \\
$F A$ & $R$ \\
$D C$ & \\
-------- & ----------- \\
$V_{\text {Assets }}$ & $V_{\text {Liabilitis }}$
\end{tabular}

Note: $G C=$ gold certificate, $F A=$ foreign assets, $D C=$ domestic credit (securities and discount loans), $C=$ currency, and $R=$ reserves.

Figure 1. Central Bank's (Fed's) Balance Sheet

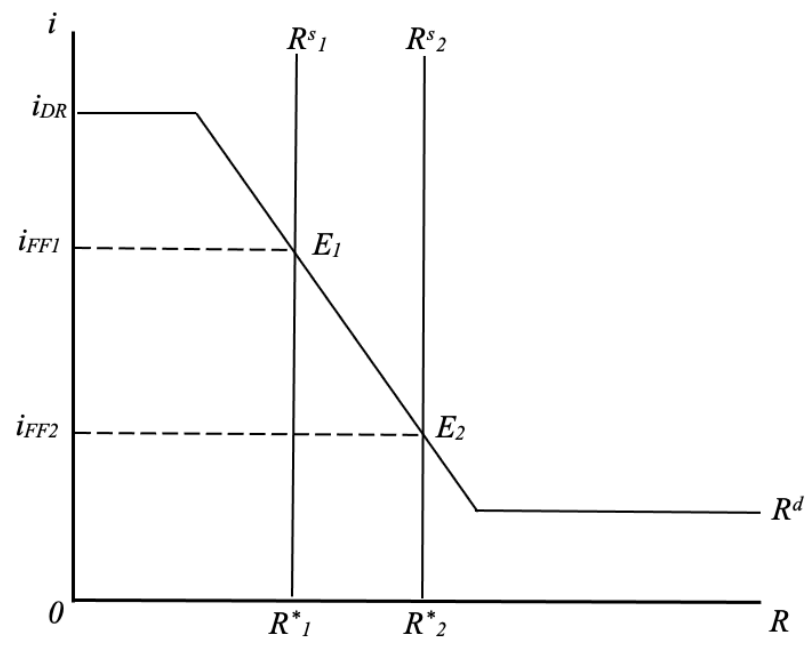

8 "As announced on March 15, 2020, the Board reduced reserve requirement ratios to zero percent effective March 26, 2020. This action eliminated reserve requirements for all depository institutions." See, Reserve Requirements, https://www.federalreserve.gov/monetarypolicy/reservereq.htm 


\section{International Journal of Social Sciences and Management Review}

Note: $i=$ interest rates, ${ }^{i}{ }_{F F}=$ federal funds rate, ${ }^{i}{ }_{D R}=$ discount rate, $R=$ reserves, $R^{d}=$ demand for reserves, $R^{s}=$ supply of reserves, $R^{*}=$ non-borrowed reserves, and $E=$ equilibrium $\left(R^{s}=R^{d}\right)$.

\section{Figure 2. Monetary Policy with Limited Reserves and Federal Funds}

Thus, Fed can lower the interest rate on discounts or overdrafts (loans to banks secured by suitable collateral, specified by the central bank). If the interest rate on such transactions is sufficiently low, commercial banks can borrow from the central bank to meet their need for reserves (RdT) and use the additional liquidity to expand their balance sheets, increasing the credit available to the economy by increasing loans or buy other profitable assets. Any time the central bank intervenes in open market to buy or sell government securities of mortgagebacked securities, it changes the side of its assets (DC) and consequently, its liabilities, eq. (1), and through the money multiplier, a multiple change in money supply takes place, eq. (2), as it is shown at the central bank's balance sheet, Figure 1.

$C+R=M B$

$M B \quad m_{M}=M^{s}$

where, $\mathrm{C}=$ currency in the hands of the public, $\mathrm{R}=$ reserves of financial institutions in the central bank, $\mathrm{MB}=$ monetary base, $m_{M}=$ money multiplier, and ${ }^{M^{s}}=$ money supply.

Financial institutions are demanding reserves ( $\mathrm{Rd})$, eq. (3), and the central bank is supplying those (Rs), eq. (4), to fulfill its role as the "lender of the last resort". The reserves are as follows:

$\mathrm{Rd}=\mathrm{RR}+\mathrm{RE}$

$\mathrm{Rs}=\mathrm{R}^{*}+\mathrm{RB}$

where, $\mathrm{Rd}=$ demand for reserves, $\mathrm{RR}=$ required reserves, $\mathrm{RE}=$ excess reserves, $\mathrm{Rs}=$ supply of reserves, $\mathrm{R}^{*}=$ non-borrowed reserves, $\mathrm{RB}=$ borrowed reserves, $r_{R}=$ required reserves ratio, $\mathrm{DD}=$ demand deposits (net transaction accounts).

Lately, since 198211 the central bank does not fix the amount of money in circulation, but it controls directly the overnight rate (it targets the federal funds rate), nor is central bank's money "multiplied up" into more loans and deposits. Although commercial banks create money through lending, they can do so freely without limit, since March 26, 2020,

\footnotetext{
${ }^{9}$ The MB was $\$ 5.150$ trillion with May 2020, it became $\$ 5.207$ trillion with January $14,2021, \$ 5.248$ trillion on February 23, 2021, \$5.447 trillion on March 23, 2021, and \$6.042 trillion om June 22, 2021. See, https://fred.stlouisfed.org/series/BOGMBASE

10 The $R_{R}=0$ since March 26, 2020. Before they were determined as follows, $R_{R}=r_{R} D D$ and the $r_{R}=10 \%$

${ }^{11}$ See, Kallianiotis (2019c).
} 


\section{International Journal of Social Sciences and Management Review}

Volume: 04, Issue: 04 "July - August 2021"

ISSN 2582-0176

because required reserves became zero. Banks are only limited in how much they can lend if they are to remain profitable in a competitive banking system because their loans rates are based on the federal funds rate, but they earn interest on their reserves, since October 2008, from the Fed12 without lending money. Prudential regulations13 also were acting as a constraint on banks' activities in order to maintain the resilience of the financial system. The households and companies who receive the money created by new lending may take actions that affect the stock of money and then, the real economy (investment, production, and employment) or the financial markets. They could quickly "destroy" the money or currency by using it to repay their existing debt or it can be multiplied, as eqs. (1) and (2) show.14

In the 1990s, central banks (Fed) began adopting formally, public inflation targets with the goal of making the outcomes, if not the process, of monetary policy more transparent. In other words, a central bank must have an inflation target of $2 \%$ for a given year. The Fed's target is based on the annual change in the overall, or "headline," PCE price index (Personal Consumption Expenditures inflation). Although the FOMC did not explicitly name an inflation target until 2012,15 St. Louis Fed President James Bullard has argued that the U.S. had "an implicit inflation target of 2 percent after 1995".16 In his presentation, Bullard noted that $2 \%$ became an international standard in the inflation targeting era that began in the 1990s.17 In the 2016 version of the Statement on Longer-Run Goals and Monetary Policy Strategy, 18 the FOMC clarified that its inflation target is symmetric (in other words, it is not

\footnotetext{
${ }^{12}$ Actually from the taxpayers, which is now, $i_{I O R}=0.15 \%$. See, https://fred.stlouisfed.org/series/IOER . The $i_{F F}^{e f f}=0.06 \%$. See, https://fred.stlouisfed.org/series/FEDFUNDS . And the target federal funds rate is: $0 \%<\bar{i}_{F F}<0.25 \%$. See, https://www.federalreserve.gov/monetarypolicy/openmarket.htm

13 But, since 1980 our regulators' policy is the opposite, "deregulation", which was also responsible for the global financial crisis and the EU debt crisis from 2007 to 2017. Thus, prudential regulations are necessary for our international monetary system to contribute to the social welfare of the nations and their people. The Depository Institutions Deregulation and Monetary Control Act of 1980 was signed by President Jimmy Carter on March 31, 1980. It gave the Fed greater control over non-member banks. (1) It forced all banks to abide by the Fed's rules. (2) It relaxed the rules under which national banks could merge. (3) It removed the power of the Federal Reserve Board of Governors under the Glass-Steagall Act to use Regulation Q to set maximum interest rates for any deposit accounts other than demand deposit accounts (with a six-year phase-out). (4) It allowed Negotiable Order of Withdrawal (NOW) accounts to be offered nationwide. (5) It raised the deposit insurance of U.S. banks and credit unions from $\$ 40,000$ to $\$ 100,000$. (6) It allowed credit unions and savings and loans to offer checkable deposits. (7) It allowed institutions to charge any loan interest rates they chose. See, "Depository Institutions Deregulation and Monetary Control Act of 1980".
} https://www.federalreservehistory.org/essays/monetary-control-act-of-1980

${ }^{14}$ See, Kallianiotis (2017a).

15 See, Press Release, January 25, 2012. "Federal Reserve issues FOMC statement of longer-run goals and policy strategy". https://www.federalreserve.gov/newsevents/pressreleases/monetary20120125c.htm

${ }^{16}$ See, Bullard (2018a). presentation from Sept. 12, 2018.

${ }^{17}$ Engemann (2019).

18 "The Federal Open Market Committee (FOMC) is firmly committed to fulfilling its statutory mandate from the Congress of promoting maximum employment, stable prices, and moderate long-term interest rates. The Committee seeks to explain its monetary policy decisions to the public as clearly as possible. Such clarity facilitates well-informed decision-making by households and businesses, reduces economic and financial uncertainty, increases the effectiveness of monetary policy, and enhances transparency and accountability, which are essential in a democratic society." See, "Statement on Longer-Run Goals and Monetary Policy Strategy Adopted effective January 24, 2012; as amended effective January 26, 2016".

https://www.federalreserve.gov/monetarypolicy/files/FOMC_LongerRunGoals_20160126.pdf 


\section{International Journal of Social Sciences and Management Review}

Volume: 04, Issue: 04 "July - August 2021"

ISSN 2582-0176

a floor or a ceiling). The FOMC added: "The Committee would be concerned if inflation were running persistently above or below this objective." In August 2020, after undershooting its $2 \%$ inflation target for years, 19 the Fed announced it would be allowing inflation to temporarily rise higher, in order to target an average of $2 \%$ over the longer term. It is still unclear if this change will make much practical difference in monetary policy anytime soon. In May 2021, the official inflation rate 20was 5\% and the SGS was giving an inflation of $13 \%$ for the same period. 21

Other major Fed's changes took place on December 20, 2008, which altered the fed funds market in a number of astonishing ways: zero fed funds rate $\left(i_{F F}=0.00 \%\right), 22$ including the types of financial institutions that were trading, the rates at which they were borrowing and lending, and the new tools introduced by the FOMC that could effectively influence these market rates. On March 20, 2020, due to the Chinese coronavirus pandemic, Fed went back to zero interest rate.23 Because banks were overflowed with reserves, their desire to borrow effectively vanished, and bank-to-bank lending largely disappeared.24 However, once the Fed started paying interest on reserves 25 to some (but not all) financial institutions, a new lending opportunity emerged. This Fed's "innovation" (paying interest of reserves) has kept

\footnotetext{
${ }^{19}$ But, in Summer 2020, the true inflation was about $10 \%$ p.a. and in December 2020, it fell to $8 \%$. See, SGS, http://www.shadowstats.com/alternate data/inflation-charts . See, also, https://ycharts.com/indicators/us_inflation_rate

${ }^{20} \mathrm{See}$, https://www.usinflationcalculator.com/inflation/current-inflation-rates/

${ }^{21} \mathrm{See}, \mathrm{http}: / /$ www.shadowstats.com/alternate data/inflation-charts

${ }^{22}$ See, "Federal Funds Target Range", https://fred.stlouisfed.org/series/DFEDTARU

23 The Federal Reserve left the target range for its federal funds rate unchanged at $0 \%-0.25 \%$ on June 10 th 2020 as expected. Policymakers reiterated they are committed to using a full range of tools to support the U.S. economy in this challenging time. The so-called dot plot of funds rate projections showed rates are expected to remain at current levels through 2022 (another "expert", Bill Gates said that the pandemic will be over in 2022). People do not trust authorities and scientists anymore. CDC is talking about a new variant in Fall 2021 to force vaccinations on all people and on children. See, https://www.cdc.gov/coronavirus/2019ncov/variants/variant.html. Fed officials see the U.S. economy shrinking $6.5 \%$ in 2020, compared to a $2 \%$ growth projected in December, but see a 5\% growth in 2021 (vs $1.9 \%$ earlier forecasted). The unemployment rate was expected to rise to $9.3 \%$ last year (vs 3.5\%) and to fall to $6.5 \%$ in 2021 (vs 3.6\%). PCE inflation was seen slowing to $0.8 \%$ (vs 1.9\%) and rebounding to $1.6 \%$ in 2021 (vs 2\%). The Fed also said it will continue to increase its bond holdings, targeting Treasury purchases at $\$ 80$ billion a month and mortgage-backed securities at $\$ 40$ billion. https://tradingeconomics.com/united-states/interest-rate . Further, the official unemployment with October 2020 was $6.9 \%$ and the SGS gives the following values: May 2020 ShadowStats Alternate Unemployment was 34.0\%, 36.5\% net of BLS errors (Flash Nos. 1435 and 1439). In November 2020, the unemployment was $26.3 \%$. http://www.shadowstats.com/alternate data/unemployment-charts and Consumer inflation- Official was $0.55 \%$ with October 2020 vs ShadowStats (1080-Based) Alternative with May 2020 was $8 \%$. And the same it was in October 2020, 8\%. http://www.shadowstats.com/alternate_data/inflation-charts. . The question is now obvious. Why would anyone trust officials again and especially the ignorant liberalglobalists?

${ }^{24}$ See, Key Features of the Federal Funds Market, Liberty Street Economics, https://libertystreeteconomics.newyorkfed.org/2018/07/size-is-not-all-distribution-of-bank-reserves-and-fedfunds-dynamics/comments/.

${ }^{25}$ The Financial Services Regulatory Relief Act of 2006 authorized the Federal Reserve Banks to pay interest on balances held by or on behalf of depository institutions at Reserve Banks, subject to regulations of the Board of Governors, effective October 1, 2011. The effective date of this authority was advanced to October 1, 2008, by the Emergency Economic Stabilization Act of 2008.
} 


\section{International Journal of Social Sciences and Management Review}

Volume: 04, Issue: 04 "July - August 2021"

ISSN 2582-0176

the deposit rate closed to zero $\left({ }^{i_{D}}=0.05 \%\right)$ for over twelve years, 26 which it is today, $r_{D}=i_{D}-\pi=0.05 \%-5 \%=-4.95 \%$ (bail in cost for the depositors), and because we are living in a free market economic system, banks charge an unethical (usurious) interest rate on credit cards of $39.99 \%$; a spread between deposit rate and credit card rate of $39.94 \%$.

Thus, the deregulation and the immunity of the financial institutions continue. A new "innovation" of the Fed came last year. The central bank considered the required reserves as a restrictive measure for the banks and so, as a non-necessary monetary instrument and made them since March 26, 2020 zero $\left(R_{R}=0\right)$, the federal funds rate zero $\left({ }^{i}{ }_{F F}=0.00 \%\right), 27$ and the effective federal funds rate with June 1,2021 was $i_{F F}^{e f f}=0.06 \% ; 28$ the discount rate was ( $\left.i_{D R}=0.25 \%\right) .29$ This precept means that it abandoned the reserve requirement ratio ( $r_{R}=0.00 \%$ ), as a monetary policy tool.30 This is a new major bank deregulation, which is

${ }^{26} \mathrm{See}$, https://www.valuepenguin.com/banking/average-bank-interest-rates

${ }^{27}$ Global and U.S. bank stocks fell Thursday (6/11/2020); DJIA lost 1,861.82 points (-6.9\%) to 25,128.17, a day after Fed officials indicated they had no plans to raise interest rates over the next two years. Shares of JPMorgan Chase JPM -8.34\% \& Co., Bank of America Corp. and Wells Fargo WFC $-9.83 \%$ \& Co. and Citigroup Inc. C $\underline{13.37 \%}$ fell between $5 \%$ and $7 \%$ early Thursday. Fed officials indicated that short-term rates would likely remain near zero through 2022, citing the coronavirus pandemic's potential to do long-term damage to the U.S. economy and a yearlong labor-market recovery. "We're not thinking about raising rates. We're not even thinking about raising rates," said Fed Chairman Jerome Powell. See, "Bank Stocks Fall After Fed Projects No Rate Increases", $\quad$ https://www.wsj.com/articles/bank-stocks-fall-after-fed-projects-no-rate-increases$11591891477 ? \bmod =\mathrm{md} \_$usstk_news

${ }^{28}$ Graph 1: Effective Federal Funds Rate

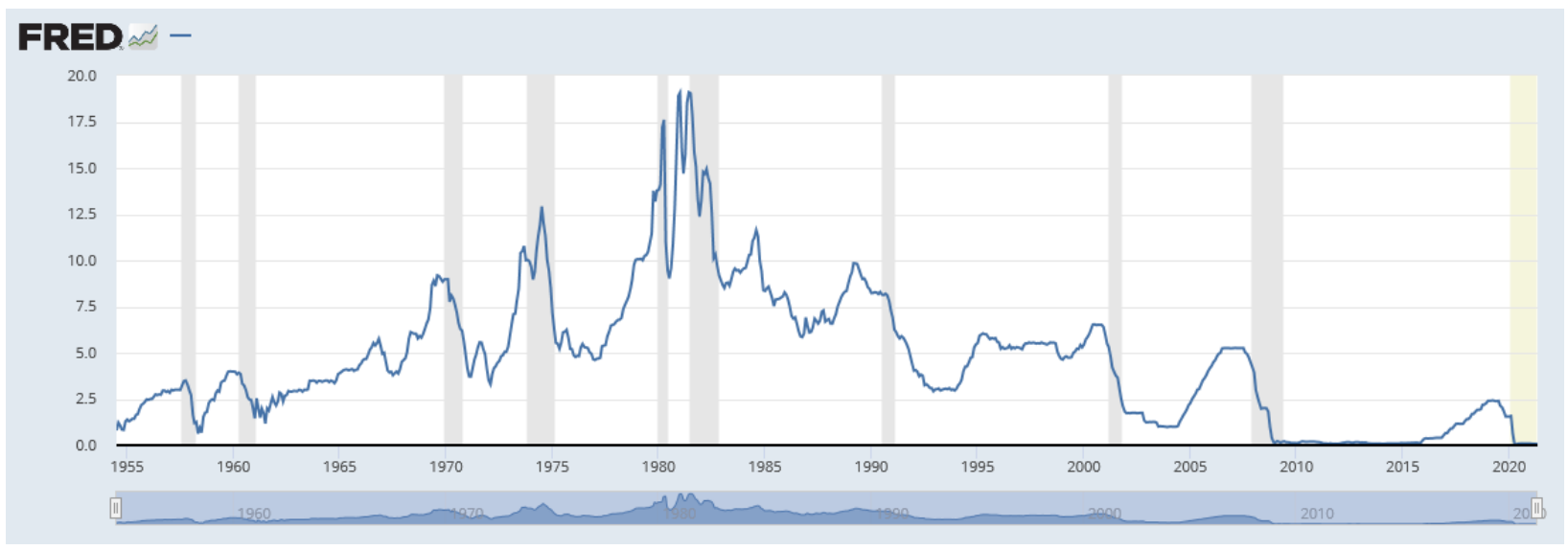

Source: https://fred.stlouisfed.org/series/FEDFUNDS

${ }^{29}$ See, Discount Rate for United States. https://fred.stlouisfed.org/series/INTDSRUSM193N

${ }^{30} \mathrm{See}$, "Fed sets $0 \%$ reserve requirement ratio, urges banks to use capital, liquidity buffers to bolster lending in face of coronavirus". https://www.regreport.info/2020/03/15/fed-sets-0-reserve-requirement-ratio-urges-banksto-use-capital-liquidity-buffers-to-bolster-lending-in-face-of-coronavirus/ . The reserve requirements started on December 23, 1913 and were abolished on March 26, 2020. See also, https://www.federalreserve.gov/newsevents/pressreleases/monetary20200315b.htm 


\section{International Journal of Social Sciences and Management Review}

very risky for the financial institutions and the economy, due to enormous liquidity.31 The Fed has substituted the required reserves with the excess reserves by supplying them in trillions of dollars $R_{E}=\$ 3.218$ trillion (May 2020). The total reserves were $\$ 3.035$ trillion with November 2020 and $\$ 3.873$ trillion with June 22, 2021.32

\section{USMM}

14

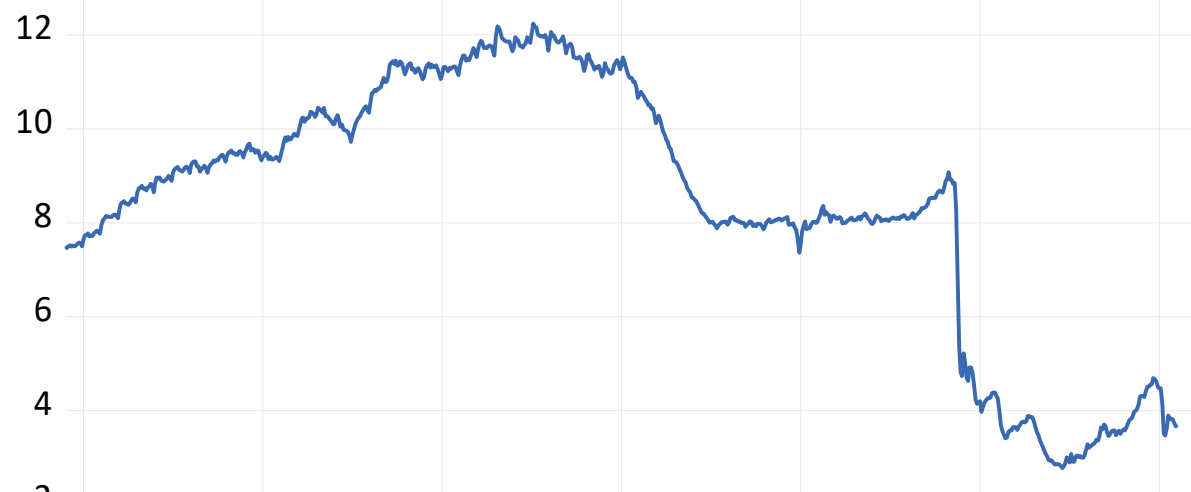

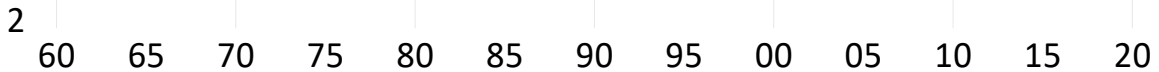

Note: USMM = U.S. Money multiplier (mM).

Source: Economagic.com and FRED.

Figure 3: Money Multiplier (M2)

31 The simple old money multiplier was $\left(m_{M}=\frac{1}{r_{R}}=\frac{1}{0.10}=10\right)$. Now, it became very large: $m_{M}=\frac{1}{r_{R}}=\frac{1}{0.0001}=10,000 ; \quad m_{M} \rightarrow \infty$. From eq. (2) we have: $m_{M}=\frac{M^{s}}{M B}$, Figure 3.

${ }^{32}$ Graph 2: Total Reserves of Depository Institutions

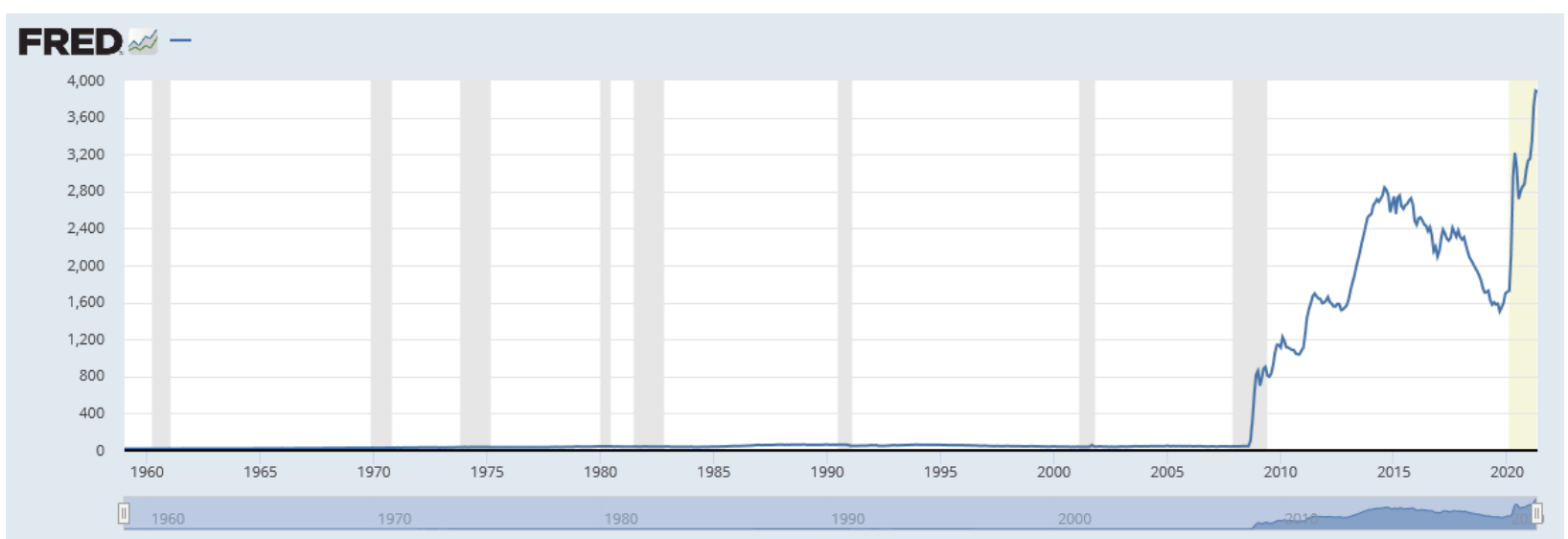

Source: https://fred.stlouisfed.org/series/TOTRESNS 


\section{International Journal of Social Sciences and Management Review}

Volume: 04, Issue: 04 "July - August 2021"

ISSN 2582-0176

The interest on reserves that Fed is paying to the banks was (January 4, 2021), $\left({ }^{i_{I O R}}=0.10 \%\right.$ ) and now (6/24/2021) $0.15 \% .33$ The 3-month T-Bill rate $(6 / 22 / 2021)$ was $i_{R F}=0.04 \%$ and in the secondary market, ${ }^{i_{R F}}=0.02 \% .34$ Money is free, due to its excess supply ( $M 2=\$ 20,278.4$ billion);35 but is this monetary policy effective, efficient, fair, ethical, and riskless? The first perspective of required reserves concerns risk. Is the zero reserve requirement ratio riskless? Is the IOR fair for the taxpayers? Is the negative real deposit rate ethical for the depositors? The reason banks hold reserves is in case that synchronization36 fails. If synchronization exists, the bank does not need to hold a lot in reserves; it can take the money that someone has deposited and give it to the other person, when he comes in to make a withdrawal. This allows the bank to devote the bulk of its funds to long-term investments that pay high rates in interest. But, an IOR is an expense for the poor taxpayers (bail out cost) and a negative real deposit rate is a (bail in cost) for the depositors and an incentive to put their savings in the risky stock markets.

\subsection{FED'S OLD OBJECTIVES AND NEW POLICY TOOLS}

The objectives of the Fed are: (1) Price stability by maintaining a sustained low inflation rate $(\pi \leq 2 \%)$ and (2) Maximum employment $\left(u \cong u^{N}\right)$. These two goals of price stability and maximum sustainable employment are known collectively as the "dual mandate".37 (3) A

${ }^{33}$ Graph 3: Interest Rate on Excess Reserves (IOER)

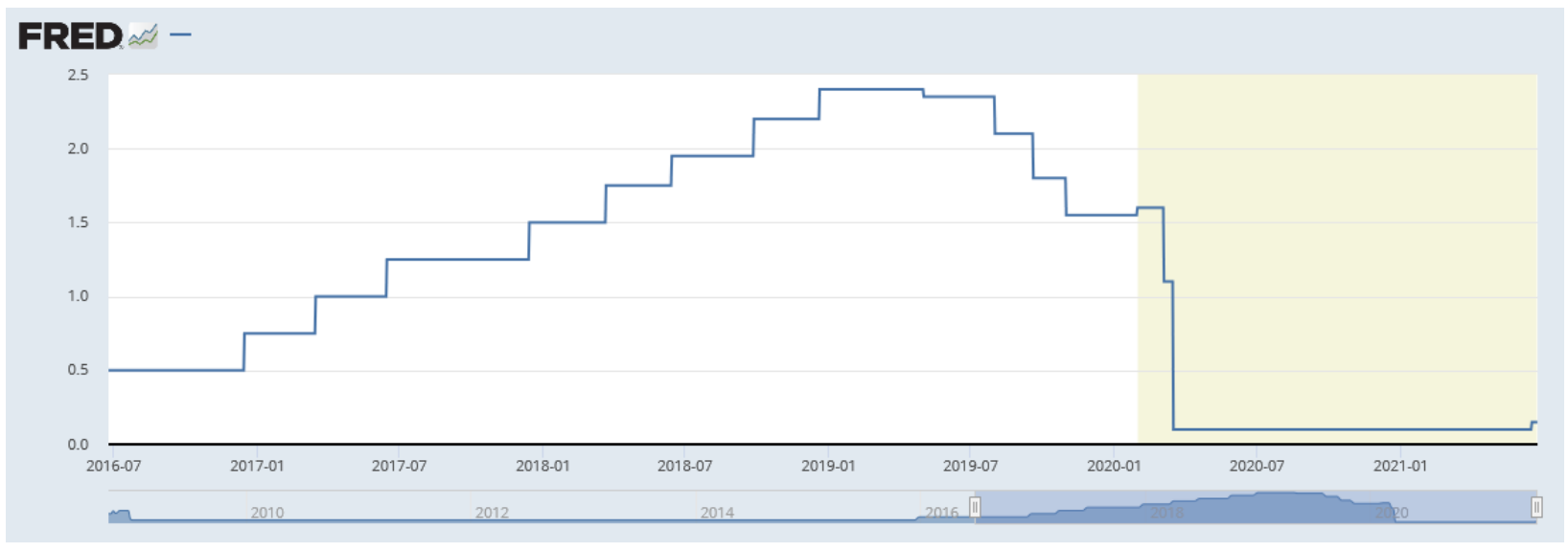

Source: https://fred.stlouisfed.org/series/IOER

${ }^{34}$ See, 3-month Treasury Bills - Secondary Market. https://fred.stlouisfed.org/series/TB3MS

${ }^{35}$ With June 1, 2020, the M2 was \$18.153 trillion, with November 23, it became \$19.121 trillion, and with June 22, 2021, it reached \$20.278 trillion. With 2020:Q1, the real GDP was \$19.011 trillion, with 2020:Q2, it was \$17.303 trillion, with 2020:Q3, it was \$18.597 trillion, with 2020:Q4, it was \$18.794 trillion, and with 2021:Q1, the real GDP was $\$ 19.086$ trillion. See, FRED, M2, https://fred.stlouisfed.org/series/WM2NS and FRED, RGDP, https://fred.stlouisfed.org/series/GDPC1. The real GDP and its L-T trend appears in Figure 4.

36 Synchronization means that on a given day, people are depositing about as much money as they are withdrawing.

37 The Federal Reserve's Federal Open Market Committee (FOMC) has translated these broad concepts into specific longer-run goals and strategies. (i) Price stability: Inflation at the rate of $2 \%$, as measured by the annual change in the Price Index for Personal Consumption Expenditures (PCE), is most consistent over the longer run with the Federal Reserve's statutory mandate. (ii) Maximum sustainable employment: Many nonmonetary factors affect the structure and dynamics of the labor market, and these may change over time and may not be 


\section{International Journal of Social Sciences and Management Review}

Volume: 04, Issue: 04 "July - August 2021"

ISSN 2582-0176

Stable real economy, maximum sustained output $\left(\bar{g}_{G D P}\right)$. (4) Stability of financial markets. (5) Moderate long-term interest rate $\left({ }^{\bar{i}_{L-T}}\right)$. (6) Equilibrium in the Balance of Payment ( $C A \cong 0$ ) and stability of the foreign exchange rate $(\bar{e})$. Then, the Fed with its monetary policy is expected to smooth the business cycle and offset shocks to the economy. The best could have been, if it was possible to prevent financial and economic crisis; but this is beyond the abilities of any public policy in our complex, interdependent, global, and controlled economy (government and institutions).38 Are the goals of maximum employment, stable prices, moderate interest rates and financial stability compatible with one another? Are all these objectives satisfied by the Fed's policies?

Many people believe that these goals are not in concordance. Conventional wisdom holds that if monetary policy is too focused on controlling inflation; then, employment and output growth will likely fall below their potential, but financial markets will be more stable than they otherwise could be, due to liquidity control. Lately, we see very few (one) of these objectives to be satisfied, even with the new monetary policy tools. Inflation is going up,39 unemployment is high,40 production very low,41 financial markets very unstable with the creation of an enormous bubble, 42 huge trade deficits 43 and depreciation of the dollar.44 There is one objective that it is satisfied, the long-term interest rate is still low. 45

measurable directly. Accordingly, specifying an explicit goal for employment is not appropriate. Instead, the Committee's decisions must be informed by a wide range of labor market indicators. Information about FOMC participants' estimates of the longer-run normal rate of unemployment consistent with the employment mandate can be found in the Summary of Economic Projections (SEP). Most recently, the median Committee participant estimated this rate to be $4.1 \%$. See, "The Federal Reserve's Dual Mandate", https://www.chicagofed.org/research/dual-mandate/dual-mandate

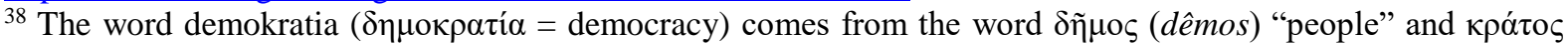
(krátos) "power", which means "the people hold power". Demos were citizens that had political and voting power, they were respecting laws and institutions, and, it was given full and absolute control of power and government. This direct democracy was used in ancient Athens and Greece since $5^{\text {th }}$ century B.C. In the modern representative democracy people are electing their government. The Preamble to the U.S. Constitution is starting with the words, "We the People", which suggests that the Constitution created and derived its power from the people, the citizens of the country. Then, people $\Rightarrow>$ government $=>$ institutions. Thus, the institutions are controlled by the government to fulfill people's objectives (their wellbeing).

${ }^{39}$ In May 2021, the official $\pi=5 \%$, https://www.usinflationcalculator.com/inflation/current-inflation-rates/

.The SGS inflation was $\pi=13 \%$, http://www.shadowstats.com/alternate data/inflation-charts

${ }^{40}$ In May, the official $u=5.8 \%$, https://tradingeconomics.com/united-states/unemployment-rate . The SGS was $\mathrm{u}=26 \%$, http://www.shadowstats.com/alternate data/unemployment-charts

${ }^{41}$ With 2021:Q1, the real GDP was \$19,086.375 billion. https://fred.stlouisfed.org/series/GDPC1 This growth was $6.4 \%$, https://tradingeconomics.com/united-states/gdp-growth. The real GDP and its L-T trend appear in Figure 4.

42 The DJIA from 6,547.05 (3/9/2009) reached 34,777.76 (5/7/2021); a growth of 28,230.71 points or $431.20 \%$ (35.43\% p.a.). See, Yahoo/Finance.

${ }^{43}$ In 2018, TA=-\$878.749 billion; in 2019, TA=-861.514 billion; in 2020, TA=- 922.026 billion. See, https://www.bea.gov/sites/default/files/2021-06/trans121-annual-hist.pdf

${ }^{44}$ Graph 4: Nominal AFE Dollar Indexes 


\section{International Journal of Social Sciences and Management Review}

Volume: 04, Issue: 04 "July - August 2021"

ISSN 2582-0176

\subsection{Monetary Policy Objectives}

Price Stability is defined by the Fed as low and stable inflation, which considered the most important goal (objective) of monetary policy $\left(\pi^{e}=2 \%\right.$ ). On the subject of inflation, some economists believe that moderate inflation helps promote full employment, economic growth and stable financial markets. Inflation is seen as enabling labor and product markets to function more smoothly in the face of shocks that could otherwise reduce employment or output. Then, central banks can boost employment and output growth more or less permanently by allowing the inflation rate to rise.46 In the 1960s, the data suggested the existence of an exploitable tradeoff between inflation and unemployment, the so-called Phillips Curve, named after the economist A.W. Phillips, who first documented that the unemployment rate and changes in wage rates moved in opposite directions in the United Kingdom.47 Some other economists argued that this menu could be improved upon if

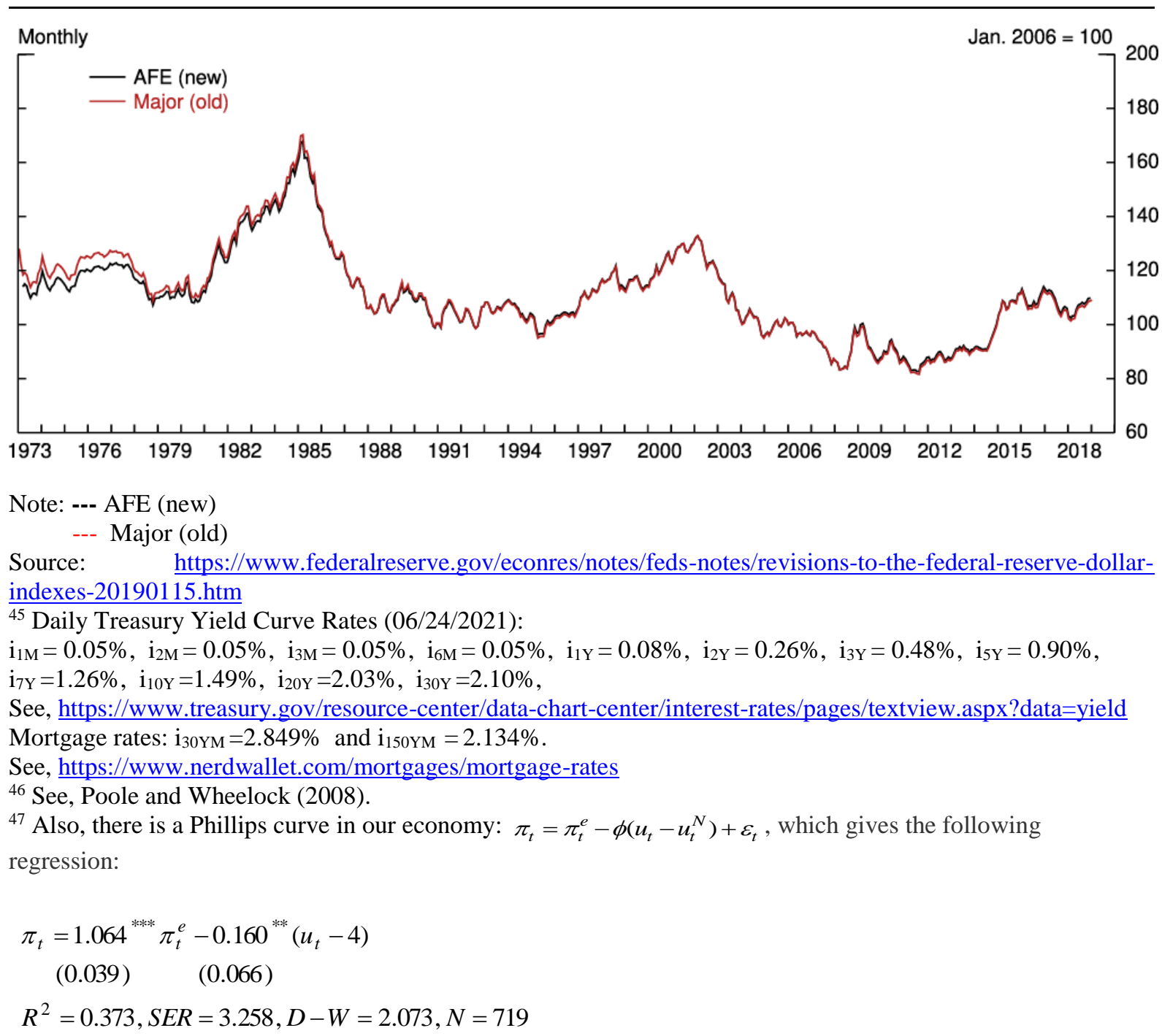

Graph 5: Inflation and Unemployment Rate 


\section{International Journal of Social Sciences and Management Review}

Volume: 04, Issue: 04 "July - August 2021"

ISSN 2582-0176

policymakers were willing to discard their old-fashioned obsession with price stability. Allow some inflation, these economists argued, and the labor market would operate more efficiently, employment would rise and the economy would grow faster. The Fed puts too much emphasis on inflation control and not enough on other objectives (i.e., on reducing business cycle fluctuations or on preventing recessions or on financial market stability or on balance of trade). Inflation targeting is a strategy that recognizes price stability as the primary long-run goal of monetary policy.

High Employment (Maximum Employment)48 is the best goal because high unemployment destroys the economy and consequently, the lives of the people (the citizens). If the output and production is declining, the human misery reduces the wellbeing of people. The economy must be at full employment ( $u \cong 0$ or at least at $u^{N}=$ natural rate of unemployment), when the economy is producing at the natural rate of output or potential output or full employment output $\left(Q^{F}\right.$ or $\left.Q^{N}\right) .49$

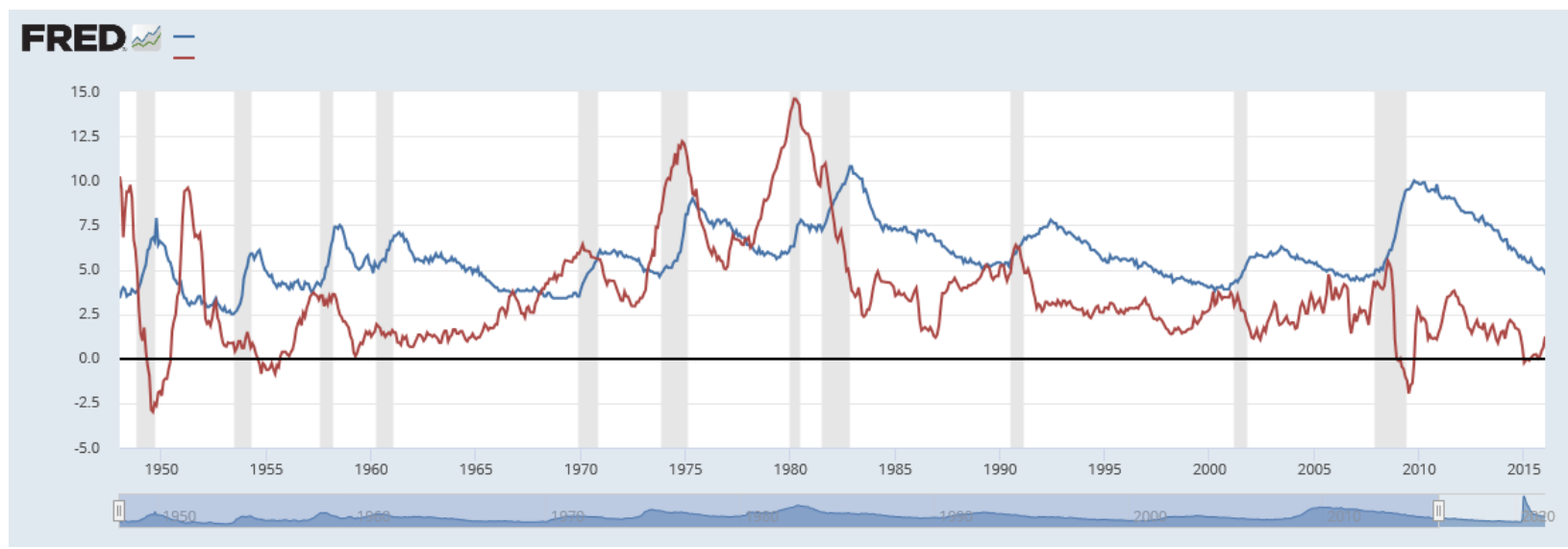

Note: $\quad$--- Unemployment Rate

--- Consumer Price Index foe All Urban Consumers: All items in U.S. City Average.

Source: https://fred.stlouisfed.org/graph/?g=3obN

48 The Federal Reserve Act of 1977 modified the original act establishing the Federal Reserve in 1913 and clarified the roles of the Board of Governors and FOMC. Congress explicitly stated the Fed's goals should be "maximum employment, stable prices, and moderate long-term interest rates". See, U.S. Government Printing Office. "Public Law 95-188 95th Congress," It is these goals that have come to be known as the Federal Reserve's Dual Mandate, https://www.chicagofed.org/research/dual-mandate/dual-mandate

49 Lately, the COVID relief funds have caused another problem. Workers are receiving unemployment compensation that exceeds the weekly wages and income. Then, people prefer to stay without work and receive

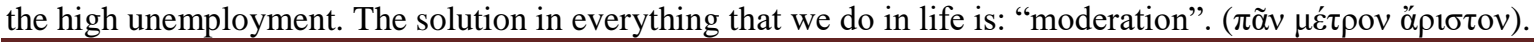




\section{International Journal of Social Sciences and Management Review}

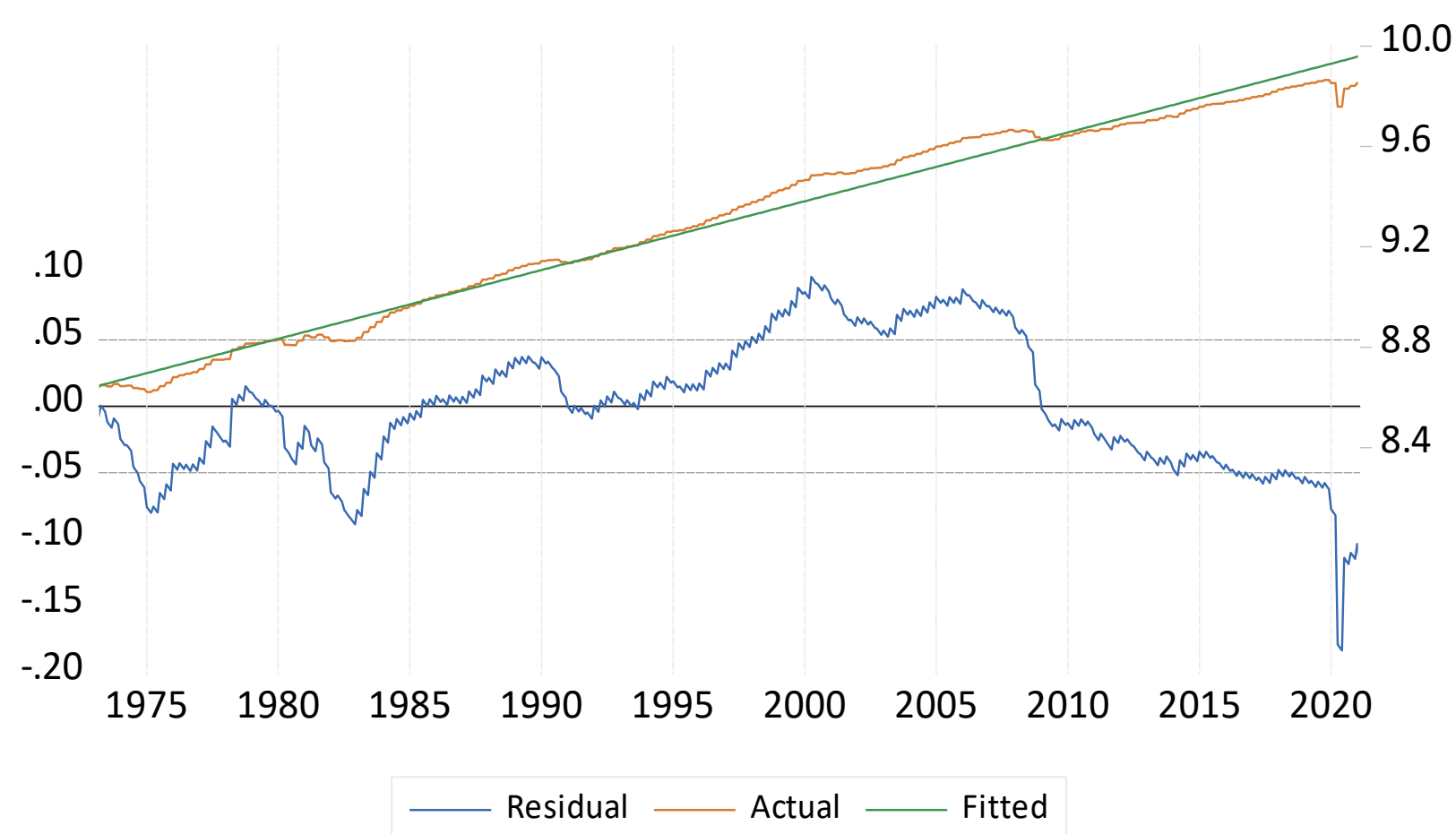

Note: Actual $=$ LUSRGDP2012, Fitted $=$ L-T trend.

Source: Economagic.com

\section{Figure 4: RGDP and its Trend}

Economic Growth or Stable Real Economy (Maximum Sustained Output). Steady economic growth $\left(\bar{g}_{G D P}\right)$ is closely related to the high employment goal. Businesses are investing when unemployment is low, people have high income and affect the aggregate demand $(A D)$ positively (increase in demand for goods and services). This is the demand-side economics. The supply-side economics intend to stimulate growth by reducing business taxes, 50 cutting regulations, and interest rates, so businesses will borrow to invest. But, if the unemployment is high, as it is lately, and the personal income low, the AD is very low. Why firms to be interested to invest? Who is going to buy their product? Then, in this case, the role of monetary policy is not very effective to boost economic growth. A moderate fiscal and trade policy can contribute to this expansionary public policy.

Stability of Financial Markets. Financial markets are providing funds to businesses to do their investments (bonds, stocks, etc.) and these instruments become available to people (suppliers of funds) for investment. But the stability of these markets $\left(\bar{g}_{D J I A}\right)$ is very important because most of the investors are risk-averse. The central bank has to stimulate these markets, but

50 These low or zero or negative (tax refund) business taxes have increased national debt from $\$ 936.7$ billion in 1980 to $\$ 28,529.4$ billion in 2021 , which is $2,945.7 \%$ (71.85\% p.a.). This debt will become unsustainable in the future. See, "55 Corporations Paid \$0 in Federal Taxes on 2020 Profits". https://itep.org/55-profitablecorporations-zero-corporate-tax/. Deregulation has also increased the risk in our markets and economy. 


\section{International Journal of Social Sciences and Management Review}

moderation is necessary; the bubbles from prolong easy money policy are very dangerous for the financial markets, as follows:

$$
\begin{aligned}
& i_{F F} \downarrow \downarrow \Rightarrow M^{s} \uparrow \uparrow \Rightarrow D^{d} \uparrow, P^{d} \uparrow, S^{d} \uparrow \Rightarrow i_{S-T} \downarrow \Rightarrow i_{L-T} \downarrow \Rightarrow k_{a} \downarrow \Rightarrow V \uparrow \uparrow \\
& \text { with } \\
& \quad V \uparrow=\frac{E B I T(1-T)}{\kappa_{a} \downarrow}
\end{aligned}
$$

And

$$
V \uparrow=D \uparrow+P \uparrow+S \uparrow
$$

The target federal funds rate must follow the reaction function that includes the DJIA:51 $\bar{i}_{F F_{t}}=\pi_{t}+r_{t}^{*}+\alpha_{\pi}\left(\pi_{t}-\pi_{t}^{*}\right)-\alpha_{u}\left(u_{t}-u_{t}^{N}\right)+\alpha_{D J I A}\left(g_{D J I A_{t}}-g_{D J I A_{t}}^{*}\right)$

where, $M^{s}=$ money supply, $(\downarrow \downarrow)=$ drastic reduction, $(\uparrow \uparrow)=$ enormous increase, ${ }^{i_{S-T}}=$ short-term interest rate, ${ }^{i_{L-T}}=$ long-term interest rate, $V=$ value of the firm, $E B I T=$ earnings before interest and taxes, $T=$ corporate tax rate, ${ }^{k_{a}}=$ average cost of capital, $D^{d}=$ demand for debt (bonds), $D=$ the value of debt, $P^{d}=$ demand for preferred stocks, $P=$ the value of preferred stocks, $S^{d}=$ demand for common stocks, $S=$ the value of common stocks, ${ }^{\bar{i}_{F F_{t}}}=$ the target federal funds rate, $\pi_{t}=$ the rate of inflation as measured by the GDP deflator, $\pi_{t}^{*}=$ the desired rate of inflation,52 $r_{t}^{*}=$ the assumed equilibrium real interest rate, $u_{t}=$ the unemployment rate, $u_{t}^{N}=$ the natural level of unemployment, $g_{D J I A_{t}}=$ the actual growth of the DJIA index, $g_{D J I A_{t}}^{*}=$ the optimal (the bubble prevention) growth of the DJIA.53

Interest-Rate Stability (Moderate Long-Term Interest Rate, ${ }^{\bar{L}_{L-T}}$ ). The interest rate stability (small fluctuations) is important for the markets, for banks, for businesses, and individuals. Large fluctuations are increasing uncertainty and cost. The interest rate must cover the expected inflation and offer a risk premium to the investor for undertaking this investment. The zero interest rate or a very high interest rate, are both causing problems to our society. 54

\footnotetext{
${ }^{51}$ See, Kallianiotis (2021a).

${ }^{52}$ The Fed ultimately stated explicitly that its target was a $2 \%$ per year increase in the raw personal consumption expenditures deflator. See, Williamson (2014, p. 112).

${ }^{53}$ The $g_{D J I A}^{*}=i_{R F}+H R P=0.05 \%+8.7 \%=8.75 \% \quad\left(i_{R F}=\right.$ the risk-free rate of interest, 3-month T-Bill and $\mathrm{HRP}=$ the historic risk premium). See, Kallianiotis (2020a).

${ }^{54}$ The optimal interest rate on deposits (savings accounts) must be: $i_{D_{t}}^{*}=\pi_{t}^{e}+1 \%\left(i_{D}^{*}=5 \%+1 \%=6 \%\right)$ and the optimal interest rate on loans (the highest) must be: $i_{L_{t}}^{*}=i_{P_{t}}+5 \%\left(i_{L}^{*}=3.25 \%+5 \%=8.25 \%\right)$ with May 2021; where $i_{D}^{*}=$ the optimal deposit rate, $\pi^{e}=$ expected true inflation rate, $i_{L}^{*}=$ the optimal loan rate, and $i_{P}=$ the prime rate. See, Kallianiotis (2017a).
} 


\section{International Journal of Social Sciences and Management Review}

We cannot have a negative real deposit rate $(\mathrm{rD}<0), 55$ as we have for more than twelve years. This is a disincentive to save and a forceful unethical and unfair policy against the risk averse depositors (bail in cost) to invest in the risky stock market.

Stability in Foreign Exchange Markets and Equilibrium in the Balance of Payment ( $\bar{e}$ and $C A \cong 0$ ). The value of the dollar affects international trade, foreign investment, and many other functions (travel, tourism, etc.). A trade account balance56 is very important for our economy because it shows our self-sufficiency, our production, our employment, and the competitiveness of the country.

$$
T A_{t}=X_{t}-M_{t}=x\left(T O T_{t}, Y_{t}^{*}\right)-m\left(T O T_{t}, Y_{t}\right)
$$

And

$$
\operatorname{TOT}_{t}=\frac{e_{t} P_{t}^{*}}{P_{t}}=\frac{P_{M}}{P_{X}}<1 \Rightarrow \frac{P_{M}(1+t)}{P_{X}} \geq 1
$$

Countries must care for their domestic economies and the interest of their citizens. These strange anti-domestic (global) policies are wrong and against the objectives of public policies (monetary). A country is competitive if $T O T>1 \Rightarrow P_{M}>P_{X}$. This can be accomplished with an import tax or tariff $(\mathrm{t})$.

The dollar return for an American investor depends on the value of the dollar with respect to the foreign currency (the exchange rate).57 An appreciated currency is increasing the return for foreign investors and so, the country attracts more foreign capital.

$$
(1+i)=\left(1+i^{*}\right)(1+f p)
$$

Or

$$
(1+i)=\left(1+i^{*}\right)(1-f d)
$$

And

$$
\text { fd or } f p=f_{t}-s_{t}
$$

where, $T A=$ trade account, $X=$ exports, $M=$ imports, $T O T=$ terms of trade, $e=$ exchange rate, $P=$ price, $\mathrm{PM}=$ price of imports, $\mathrm{PX}=$ price of exports, $\mathrm{t}=$ tariff, $Y=$ income, $i=$

\footnotetext{
55 The $r_{D}=0.05 \%-5 \%=-4.05 \%$ with the official inflation and $r_{D}=0.05 \%-13 \%=-12.95 \%$ with the SGS inflation (May 2021).

56 The country has an enormous trade deficit $(\mathrm{TA}<0)$. See, footnote 43.

${ }^{57}$ There is a fluctuation of the dollar value overtime. A dollar exchange rate index is given in Graph 4 , footnote 44.
} 


\section{International Journal of Social Sciences and Management Review}

Volume: 04, Issue: 04 "July - August 2021"

ISSN 2582-0176

interest rate, $f p=$ forward premium, ${ }^{f d}=$ forward discount, $f_{t}=$ the $\ln$ of forward exchange rate, ${ }^{s_{t}}=$ the $\ln$ of spot exchange rate, and a ${ }^{*}=$ denotes the foreign variable.

\subsection{Monetary Policy Tools}

Banks hold currency (vault cash) and reserves (required reserves, $R_{R}$, until March 26, 2020 and excess reserves, RE up to now). (Sic). The Fed supplies reserves into the banking system through open market operations (non-borrowing reserves, $R^{*}$ ) by purchasing securities in the open market (primary dealers) or by making loans (borrowing reserves, $R_{B}$ ) through the discount window, eq. (4). An open market purchase ( $O M P$ ) leads to an expansion of reserves in the banking system and increases domestic credit ( $D C$ ) in Fed's Balance Sheet, Figure 1. An open market sale ( $O M S$ ) leads to a contraction of reserves in the banking system and reduction in domestic credit. Banks' reserves are increasing when they borrow from Fed's discount window (borrowed reserves, $R_{B}$ ) by paying an interest rate (the discount rate, ${ }^{i_{D R}}$ ). This discount loan leads to an expansion of reserves and increases liquidity in the banking system. The opposite effects take place, when the bank repays the discount loan.

The Fed introduced new lending programs during the global financial crisis in 2007-2008.58 Thus, the Federal Reserve has a variety of policy tools that it was using in the past or it is still using them, now, in order to implement monetary policy and support the economy during the financial crisis and the latest coronavirus economic, healthcare, and social crisis. These instruments are the followings: (I) Open Market Operations, (II) Discount Window and Discount Rate, (III) Reserve Requirements, (IV) Interest on Required Reserve Balances and Excess Balances, (V) Overnight Reverse Repurchase Agreement Facility, (VI) Term Deposit Facility, (VII) Commercial Paper Funding Facility, (VIII) Primary Dealer Credit Facility, (IX) Money Market Mutual Fund Liquidity Facility, (X) Primary Market Corporate Credit Facility, (XI) Secondary Market Corporate Credit Facility, (XII) Term Asset-Backed Securities Loan Facility, (XIII) Paycheck Protection Program Liquidity Facility, (XIV) Municipal Liquidity Facility, (XV) Main Street Lending Program, (XVI) Central Bank Liquidity Swaps, (XVII) Temporary Foreign and International Monetary Authorities (FIMA) Repo Facility, (XVIII) Expired Policy Tools, and (XIX) Margin Requirements59

\subsubsection{Open Market Operations}

\footnotetext{
58 They were: (1) Term Auction Facility (TAF) on December 12, 2007. (2) Term Securities Lending Facility (TSLF) on March 11, 2008. (3) Swap Lines on March 11. 2008. (4) Loans to J.P. Morgan to buy Bear Sterns on March 14, 2008. (5) Primary Dealer Credit Facility (PDCF) on March 16, 2008. (6) Loans to AIG on September 16, 2008. (7) Asset-Backed Commercial Paper Money Market Mutual Fund Liquidity Facility (AMLF) on September 19, 2008. (8) Commercial Paper Funding Facility (CPFF) on October 7, 2008. (9) Money Market Investor Funding Facility (MMIFF) on October 21, 2008. (10) Term Asset-Backed Securities Loan Facility (TALF) on November 25, 2008. See, Mishkin and Eakins (2018, p. 224).

${ }^{59}$ See, Overview of Margin Requirements. https://www.finra.org/rules-guidance/key-topics/margin-accounts . Also, https://www.investopedia.com/terms/i/initialmargin.asp . Further, All Regulations, https://www.federalreserve.gov/supervisionreg/reglisting.htm
} 


\section{International Journal of Social Sciences and Management Review}

Volume: 04, Issue: 04 "July - August 2021"

ISSN 2582-0176

Open market operations (OMOs)60 are the purchase and sale of securities (government bonds, agency bonds, and mortgage-back securities) in the open market by the central bank. The short-term objective for OMO is specified by the Federal Open Market Committee (FOMC).61 Before the global financial crisis in 2008, the Federal Reserve used OMOs to adjust the supply of reserve balances and to keep the federal funds rate $\left({ }^{i}{ }_{F F}\right)$ around the target ( $0.00 \%-0.25 \%$ since March 16, 2020) established by the FOMC.

The federal funds rate is affecting the interest rate paid on reserves. An open market purchase (OMP) leads to a greater quantity of reserves supplied and shifts the $R^{s}$ curve from point E1 to the right to point $E_{2}$, Figure 5. The amount of non-borrowed reserves increases to $R_{2}^{*}$ and the ${ }^{i_{F F_{1}}}$ falls to ${ }^{i_{F F_{2}}}$. An open market sale (OMS) decreases the quantity of non-borrowed reserves supplied and the supply curve shifts to the left and the iFF increases, Figure 5.

$$
\begin{aligned}
& \text { OMP } \Rightarrow \text { Securities } \uparrow \Rightarrow R^{*} \uparrow \Rightarrow R^{s} \uparrow \Rightarrow i_{F F} \downarrow \\
& \text { OMS } \Rightarrow \text { Securities } \downarrow \Rightarrow R^{*} \downarrow \Rightarrow R^{s} \downarrow \Rightarrow i_{F F} \uparrow
\end{aligned}
$$

The open market operations are of two types: (1) Dynamic open market operations that change the level of reserves and (2) Defensive open market operations, which offset movements in other factors that affect reserves. The FOMC sets the target federal funds rate ( $\bar{i}_{F F}$ ) and the trading desk of the New York Fed executes the operations.62

FOMC $\Rightarrow$ sets $\Rightarrow \bar{i}_{F F_{t}} \Rightarrow$ implementation regime $\Rightarrow i_{S-T_{t}}$ and $i_{S-T_{t+1}} \Rightarrow i_{L-T_{t}} \Rightarrow$

and financial conditions $\Rightarrow C$ and $I \Rightarrow Q \Rightarrow u^{N}$ and $\bar{P}$

In a repurchase agreement (repo),63 the Fed purchases Treasury securities with an agreement that the seller will repurchase them in a short period (from 1 to 15 days). Thus, the repo is a temporary OMP and is used for a defensive OMP, which will be reversed in a few days. When the Fed wants to conduct a temporary OMS, it engages in a reverse repurchase agreement (matched sale-purchase transaction), in which the Fed sells securities and the buyer agrees to sell them back to the Fed in a short period.

\subsubsection{The Discount Window and Discount Rate}

Federal Reserve lending to depository institutions (the "discount window") plays an important role in supporting the liquidity and stability of the banking system and the effective

\footnotetext{
${ }^{60}$ See, "Open market operations (OMOs)". https://www.federalreserve.gov/monetarypolicy/openmarket.htm

${ }^{61}$ See, Federal Open Market Committee (FOMC), https://www.federalreserve.gov/monetarypolicy/fomc.htm

${ }^{62}$ See, A Day at the Trading Desk, Mishkin and Eakins (2018, p. 219). See also, "The Federal Reserve's Open Market Operations", https://www.learningmarkets.com/the-federal-reserves-open-market-operations/ . Further, "Domestic Market Operations", https://www.newyorkfed.org/markets/domestic-market-operations .

${ }^{63}$ See, "Repurchase Agreement Operational Details", https://www.newyorkfed.org/markets/domesticmarket-operations/monetary-policy-implementation/repo-reverse-repo-agreements/repurchase-agreementoperational-details . See also, "Repo and Reverse Repo Agreements",

https://www.newyorkfed.org/markets/domestic-market-operations/monetary-policy-implementation/reporeverse-repo-agreements
} 


\section{International Journal of Social Sciences and Management Review}

implementation of monetary policy. By providing ready access to funding, the discount window helps depository institutions manage their liquidity risks efficiently and avoid actions that have negative consequences for their customers, such as withdrawing credit during times of market stress. Thus, the discount window supports the smooth flow of credit to households and

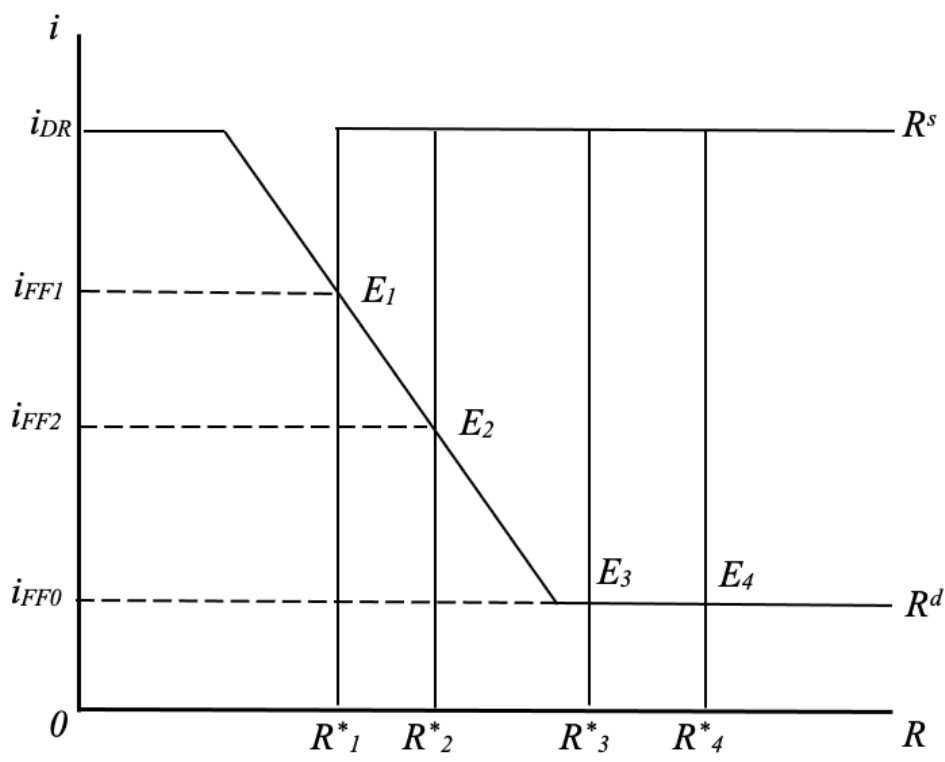

Note: ${ }^{i}=$ interest rates, ${ }^{i}$ FF $=$ federal funds rate, ${ }^{i}{ }_{D R}=$ discount rate, $R=$ reserves, $R^{d}=$ demand for reserves, $R^{s}=$ supply of reserves, $R^{*}=$ non-borrowed reserves, $E$ = equilibrium ( $R^{s}=R^{d}$ ).

\section{Figure 5. Monetary Policy with Limited Reserves}

Businesses. The discount rate $\left({ }^{i_{D R}}\right) 64$ is the interest rate charged to commercial banks and other depository institutions on loans they receive from their regional Federal Reserve Bank's lending facility, the discount window. All discount window loans are fully secured. Lately, with this enormous Fed's liquidity by supplying non-borrowed reserves $\left(R^{*}\right)$, there is no need for the discount window borrowing, Figure 5, point E4 .

The discount rate was $1 \%$ above the target federal funds rate $\left({ }_{D R}=\bar{i}_{F F}+1 \%\right)$; but due to the global financial crisis in 2007, the Fed lowered the ${ }^{i_{D R}}$ to $0.50 \%$ above the federal funds rate

${ }^{64}$ See, "Discount Rate",

https://www.investopedia.com/terms/d/discountrate.asp\#: :text=While\%20the\%20discount $\% 20$ rates\%20for $\% 2$ 0the\%20first\%20two,based\%20on\%20the\%20prevailing\%20rates\%20in\%20the\%20market. Now, it is $i_{D R}=0.25 \%$. See, https://www.nasdaq.com/market-activity/fixed-income/disc/historical . See also, https://www.bankrate.com/rates/interest-rates/federal-discount-rate.aspx . The 3-month T-Bill rate was $i_{R F}=0.08 \%$ and lately, it became $i_{R F}=0.04 \%$. See, https://ycharts.com/indicators/3 month $\mathrm{t}$ bill . Then, $i_{D R}=i_{R F}+0.20 \% \cong 0.08 \%+0.20 \% \cong 0.25 \%$ or $i_{D R}=i_{R F}+0.20 \% \cong 0.04 \%+0.20 \% \cong 0.25 \%$. See, current discount rate, https://www.frbdiscountwindow.org/pages/discount-rates/current-discount-rates 


\section{International Journal of Social Sciences and Management Review}

Volume: 04, Issue: 04 "July - August 2021"

ISSN 2582-0176

$\left({ }^{i}{ }_{D R}=\bar{i}_{F F}+0.50 \%\right)$ and in March 2008 to $0.25 \%$ above the federal funds rate that it is today: $i_{D R}=\bar{i}_{F F}+0.25 \%=0.00 \%+0.25 \%=0.25 \%$. The use of the discount window was limited because it had a stigma on the banks that they are in trouble and have to borrow from the Fed. But, banks could use the discount window without making this action a public knowledge.

Thus, banks can borrow reserves from the Fed's discount window, which has been created as the lender of the last resort.65 The discount loans are three types: (1) Primary Credit, (2) Secondary Credit, and (3) Seasonal Credit.

Primary Credit66 is the most important discount lending in monetary policy and banks are borrowing as much as they need, mostly overnight, and it is referred as "standing lending facility". The interest rate67 is the discount rate or the primary credit rate $\left(i_{D R}^{P}=0.25 \%\right)$ since $3 / 16 / 2020$ and it is higher than the federal funds rate (target $\bar{i}_{F F}=0.00 \%$ to $0.25 \%$ and $\left.i_{F F}^{\text {eff }}=0.08 \%\right) .68$ The discount rate exceeds the federal funds rate $\left(i_{D R}>i_{F F}\right)$ and so banks borrow from each other in the federal funds market. The primary credit facility has put a ceiling on the federal funds rate at ${ }^{i}$. Figure 5.

The Secondary Credit is given to banks that are having financial (liquidity) problems. This secondary credit rate is $0.50 \%$ above the primary credit rate. Now, it is $i_{D R}^{s}=0.75 \%$ since $3 / 16 / 2020$.

The Seasonal Credit is given to meet the needs of small banks in periods of vacations and in agricultural areas that they have a seasonal pattern for credit.69 Now, it is $0.15 \%$.

${ }^{65}$ See, "Federal Reserve Act", https://www.federalreserve.gov/aboutthefed/fract.htm. Also, "The Meeting at Jekyll Island", https://www.federalreservehistory.org/essays/jekyll-island-conference . Further, "JFK's Executive Order 11110 Abolishing the Federal Reserve", https://truth11.com/2020/06/03/jfks-executive-order11110-abolishing-the-federal-reserve/

${ }^{66}$ See, "The Primary \& Secondary Lending Programs", https://www.frbdiscountwindow.org/Pages/GeneralInformation/Primary-and-Secondary-Lending-

Programs.aspx\#: :text=The\%20\%22Primary\%20Credit\%22\%20program\%20is\%20the\%20principal\%20safety, normally $\% 20$ granted $\% 20$ on $\% 20 \mathrm{a} \% 20 \% \mathrm{E} 2 \% 80 \% 9$ Cno-questions-

asked $\% 2 \mathrm{C} \% \mathrm{E} 2 \% 80 \% 9 \mathrm{D} \% 20 \mathrm{minimally} \% 20 \mathrm{administered} \% 20 \mathrm{basis}$. See also,

https://www.dallasfed.org/banking/discount/primary

${ }^{67}$ See, "Federal Reserve Discount Rate", https://www.thebalance.com/federal-reserve-discount-rate-

3305922\#: :text=The\%20primary \%20credit $\% 20$ rate $\% 20$ is $\% 20$ the $\% 20$ basic $\% 20$ interest,needed $\% 20$ to $\% 20$ achie ve\%20the\%20primary\%20rate. $\% 20$ It $\% 27 \mathrm{~s} \% 202.75 \% 25$.

${ }^{68}$ See, "Federal Funds Data", https://apps.newyorkfed.org/markets/autorates/fed\%20funds . See also, "Effective Federal Funds Rate (FEDFUNDS)", https://fred.stlouisfed.org/series/fedfunds

69 See, "Seasonal Lending Program", https://www.frbdiscountwindow.org/Home/Pages/GeneralInformation/Seasonal-Lending-Program . "The interest rate charged on seasonal credit loans is a floating market rate comprised of the average of the previous two-weeks average federal funds rate and the secondary market rate on three-month large CDs rounded to the nearest five basis points. The interest rate is reset every two weeks and applies to all outstanding seasonal credit loans on the first day of the reserve maintenance period." See, https://www.newyorkfed.org/banking/seasonalcredit.html. See also,

https://www.frbdiscountwindow.org/Home/Pages/General-Information/Seasonal-Lending-Program\#intratesfees 


\section{International Journal of Social Sciences and Management Review}

Volume: 04, Issue: 04 "July - August 2021"

ISSN 2582-0176

The Fed is using the discount window to influence the amount of reserves and also to prevent financial panics. But, this increases the social cost because banks are willing to take on more risk knowing that the Fed (and the FDIC) will come to their rescue. Hence, banks take on more risk, as it happened before 2008, and exposed taxpayers to enormous losses by bailing them out. This moral hazard problem is a serious social and ethical problem of our unregulated banks and it is related to the "too big to fail" theory.

\subsubsection{Reserve Requirements}

The Federal Reserve Act70 authorizes the Board to establish reserve requirements $\left(R_{R}\right)$ within specified ranges for purposes of implementing monetary policy on certain types of deposits and other liabilities of depository institutions.71 For many years, reserve requirements played a central role in the implementation of monetary policy by creating a stable demand for reserves. In January 2019, the FOMC announced its intention to implement monetary policy in an ample reserves regime. As announced on March 15, 2020,72 the Board reduced reserve requirement ratios $\left({ }_{R}\right)$ to zero percent effective March 26, 2020. This action eliminated reserve requirements for all depository institutions. This extreme deregulation of the financial institutions will cause instability and high risk in the entire industry and the poor taxpayers will be charged without asking them to bail out the banks and no one should criticize central bank for its policy because, it is "independent". Yes, independent from citizens' welfare maximization.

\subsubsection{Interest on Required Reserve Balances and Excess Balances}

The Federal Reserve Bank pays interest on required reserve balances and on excess reserve balances (IOR).73 For what reason idle reserves to receive interest? This neo-liberal figment is inconceivable, peculiar, and unethical. The Financial Services Regulatory Relief Act of 200674 authorized the Federal Reserve Banks to pay interest on balances held by or on behalf of depository institutions at Reserve Banks, subject to regulations of the Board of Governors, effective October 1, 2011. The effective date of this authority was advanced to October 1, 2008, by the Emergency Economic Stabilization Act of 2008.75

\footnotetext{
${ }^{70}$ See, Federal Reserve Act. https://www.federalreserve.gov/aboutthefed/fract.htm

${ }^{71}$ The reserve requirements (reserve requirement ratio) were: Net transaction accounts from $\$ 0$ to $\$ 10.3$ million, $r_{R}=0 \%$; more than $\$ 10.3$ million to $\$ 44.4$ million, $r_{R}=3 \%$; and more than $\$ 44.4$ million, $r_{R}=10 \%$. Since March 26, 2020, the $r_{R}=0 \%$. See, "Reserve Requirements", https://www.educba.com/reserve-requirements/

${ }^{72}$ See, Federal Reserve Actions to Support the Flow of Credit to Households and Businesses, https://www.federalreserve.gov/newsevents/pressreleases/monetary20200315b.htm

${ }^{73}$ The Fed's interest on reserves was, $i_{\text {IOR }}=0.10 \%$ since $3 / 16 / 2020$ and now, it is, $i_{I O R}=0.15 \%$. See, https://www.federalreserve.gov/monetarypolicy/reqresbalances.htm

${ }^{74}$ See, FINANCIAL SERVICES REGULATORY RELIEF ACT OF 2006, https://www.congress.gov/109/plaws/publ351/PLAW-109publ351.pdf

${ }^{75}$ DIVISION A-EMERGENCY ECONOMIC STABILIZATION, https://www.congress.gov/110/plaws/publ343/PLAW-110publ343.pdf
} 


\section{International Journal of Social Sciences and Management Review}

The cost of holding reserves is their opportunity cost, the interest rate that could have been earned on lending these reserves out to business and individual borrowers. After 2008 and up to now; the IOR is:

$I O R=R_{T} i_{I O R}$

The supply of reserves $\left(R^{s}\right)$ can be broken into two components, the amount of reserves supplying by the Fed's open market operations, non-borrowed reserves $\left(R^{*}\right)$ and the amount of reserves borrowed from the Fed, borrowed reserves $\left(R_{B}\right)$, eq. (4). The cost of borrowing from the Fed is the discount rate $\left({ }^{i_{D R}}\right)$. If the ${ }^{i_{F F}<i_{D R}}$, banks will not borrow from the Fed's discount window and $R_{B}=0$; they will borrow from the federal funds market. Then, $R^{s}=R^{*}$.

If the federal funds rate $\left({ }^{i} F_{0}\right)$ is at the level of the flat demand for reserves, equilibrium point $E_{3}$, open market operations have no effect on the federal funds rate; from $E_{3}$, it goes to $E_{4}$ and the federal funds rate stays at ${ }^{i_{F F_{0}}}$, Figure 5 . This is a floor for the federal funds rate, as it is now $\left({ }_{F F}=0 \%\right)$. There is only an increase in reserves $(R)$, which raises the monetary base ( $M B$ ) and through the money multiplier ( $m_{M}$ ) increases the money supply ( $M^{s}$ ), eqs. (1) and (2); contributing enormous liquidity in the economy, bubbles in the stock market, and high inflation expectations. The risk is going up in the financial market because the bubble can very easily burst.

$R^{d}$ flat section $\Rightarrow$ OMP $\Rightarrow$ Securities $\uparrow \Rightarrow R^{*} \uparrow \Rightarrow R_{3}^{*} \Rightarrow R_{4}^{*} \Rightarrow i_{F F_{0}}($ cons $\tan t)$

When the Fed reduces or increases the discount rate, but $i_{D R}>i_{F F}$, there are no effects on the federal funds rate and no effect on the reserves. Now, in case that a reduction of the discount rate takes place and $i_{D R}=i_{F F}$, the supply of reserves will fall $\left(R^{s} \downarrow\right)$ and the borrowed reserves increase $\left(R_{B} \uparrow\right)$.

$i_{D R} \downarrow \Rightarrow Q_{R_{B}}^{d} \uparrow \Rightarrow R^{d} \uparrow \Rightarrow R \uparrow \Rightarrow M B \uparrow \Rightarrow M^{s} \uparrow$

When the required reserve ratio $\left({ }_{R}\right)$ increases, required reserves $\left(R_{R}\right)$ increase, and the quantities of reserves demanded $\left(Q_{R}^{d}\right)$ increases and the federal funds rate $\left({ }^{i}{ }_{F F}\right)$ increases. The opposite if $r_{R}$ falls.

$r_{R} \uparrow \Rightarrow R_{R} \uparrow \Rightarrow Q_{R}^{d} \uparrow \Rightarrow i_{F F} \uparrow$

The interest on reserves (IOR) can shift the demand for reserves $\left(R^{d}\right)$ up and affects the interest rate $\left({ }^{i}{ }_{I O R}\right)$, but not the quantity of non-borrowed reserves $\left(R^{*}\right)$, Figure 6 . When 


\section{International Journal of Social Sciences and Management Review}

$i_{F F_{1}}=i_{I O R_{1}}$, the equilibrium between $R^{d}$ and $R^{s}$ is at point $E_{1}$. An increase on the ${ }^{i_{I O R}}$ from $i_{I O R_{1}}$ to $i_{I O R_{2}}$ moves the equilibrium to $E_{2}$ and federal funds rate to ${ }^{i_{F F_{2}}}$, Figure 6 .

\subsubsection{Overnight Reverse Repurchase Agreement Facility}

In the Policy Normalization Principles and Plans 76 announced on September 17, 2014, the Federal Open Market Committee (FOMC) indicated that it intended to use an overnight reverse repurchase agreement ( $O N R R P$ ) facility as needed, as a supplementary policy tool to help control the federal funds rate and keep it in the target range set by the FOMC. The Committee stated that it would use an $O N R R P$ facility only to the extent that it will be necessary and will phase it out when it is no longer needed to help control the funds rate. When the Federal Reserve conducts an overnight $R R P$, it sells a security to an eligible counterparty and simultaneously agrees to buy

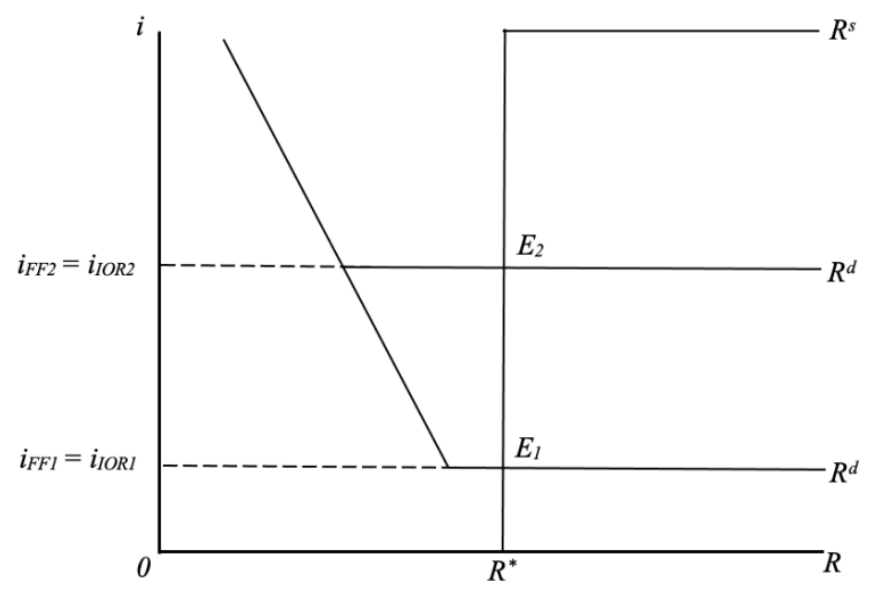

Note: ${ }^{i}=$ interest rates, ${ }^{i}{ }_{F F}=$ federal funds rate, ${ }^{i}{ }_{I O R_{1}}=$ interest on reserves, $R=$ reserves, $R^{d}$ = demand for reserves, $R^{s}=$ supply of reserves, $R^{*}=$ non-borrowed reserves, and $E=$ equilibrium $\left(R^{s}=R^{d}\right)$.

\section{Figure 6. Interest on Reserves}

The security back the next day. The Federal Reserve currently conducts $O N R R P$ operations with many counterparties, covering a wide range of entities, 77 as it is discussed below and it is shown in Figure 7.

\subsubsection{Margin Requirements}

\footnotetext{
76 See, "FOMC Communications Related to Policy Normalization". On October 11, 2019, the FOMC released a statement that outlined its plans to ensure that the level of reserves in the banking system remains ample. https://www.federalreserve.gov/monetarypolicy/policy-normalization.htm

${ }^{77}$ See, "Reverse Repo Counterparties". https://www.newyorkfed.org/markets/rrp_counterparties.html 


\section{International Journal of Social Sciences and Management Review}

Under Regulation $\mathrm{T}$, a security can generally be classified as belonging to one of three categories: (1) margin, (2) non-margin, or (3) exempted security. U.S. broker-dealers are prohibited from extending credit against non-margin securities, unless the loan is a nonpurpose loan, that is, for a purpose other than buying, carrying, or trading in securities (see section 220.6(e) of Regulation T).78 Broker-dealers may extend purpose credit against margin and exempted securities. Exempted securities are defined in section 3(a) (12) of the Act to include government and municipal securities. Broker-dealers may extend up to 50\% loan value against margin equity securities. 79 Broker dealers may extend "good faith" credit against debt and exempted securities. Margin requirements are listed in section 220.12 of Regulation T. The $r_{m}=50 \%$ since 1974.80 Then, it is an ineffective tool because it is not in use. This low margin requirement is contributing to the financial bubble. 81

\subsection{Fed's "Innovations"}

Banks held reserves to meet the Fed's regulatory reserve requirements $\left(R_{R}\right)$ and some excess reserves $\left(R_{E}\right)$ to meet the banking demands of their customers. The interest on reserves $\left(R_{R}+R_{E}=R_{T}^{d}\right)$ was zero $\left({ }^{i}{ }_{I O R}=0\right)$. When banks needed extra reserves to meet their demands, they were borrowing these reserves from the federal funds market. If banks had excess reserves, they could lend them in the federal funds market at the ${ }^{i}{ }_{F F}^{e f f}$. The demand and supply of reserves are depicted in Figure 2. To raise the ${ }^{i}{ }_{F F}$, the Fed decreases the supply of reserves $\left(R_{1}^{s}\right)$ by selling U.S. Treasury securities in the open market. To lower the $i_{F F}$, the Fed increases the supply of reserves $\left(R_{2}^{s}\right)$ by buying government securities in the open market. After 2008, the Fed has changed the way it implements monetary policy. It has, now, two overnight interest rates: (1) Interest rate paid on banks' reserves $\left({ }^{i_{I O R}}\right)$ and (2) Interest rate on

\footnotetext{
${ }^{78}$ Regulation $\mathrm{T}$ is a collection of provisions that govern investors' cash accounts and the amount of credit that brokerage firms and dealers may extend to customers for the purchase of securities. According to Regulation $\mathrm{T}$, an investor may borrow up to $50 \%$ of the purchase price of securities that can be bought using a loan from a broker or dealer. The remaining $50 \%$ of the price must be funded with cash. See,

https://web.archive.org/web/20170710145033/https://www.ecfr.gov/cgi-bin/textidx?SID=b2233140b41b2612baec30f988b8357c\&mc=true\&node=se12.3.220_112\&rgn=div8 . Also see, https://web.archive.org/web/20180621064548/https://www.ecfr.gov/cgi-bin/textidx?tpl=\%2Fecfrbrowse \%2FTitle12\%2F12cfr220_main_02.tpl And https://www.investopedia.com/terms/r/regulationt.asp , Further, Margin Requirements, https://www.firstrade.com/content/en-us/education/margin/marginrequirements/

${ }^{79} \mathrm{See}$, https://www.federalreserve.gov/supervisionreg/legalinterpretations/margin requirements20080305.pdf . See also, https://www.finra.org/rules-guidance/key-topics/margin-accounts\#overview . In addition, https://www.federalreserve.gov/supervisionreg/reglisting.htm

${ }^{80}$ See, Simon Kwan (2000), “Margin Requirements as a Policy Tool?”. https://www.frbsf.org/economicresearch/publications/economic-letter/2000/march/margin-requirements-as-a-policy-tool/

81 "The Federal Reserve has chosen to set only the initial margin requirement. The maintenance margin, which determines the leverage on a continuing basis, is set by the exchanges and brokers. Currently, the New York Stock Exchange (NYSE) and the National Association of Securities Dealers (NASD) generally require member firms to impose a minimum $25 \%$ maintenance margin requirement on their customers. In practice, the house margins set by individual brokerage firms are higher, and some brokerage firms further differentiate their margin requirements by individual stocks and the trading behavior of their customers." See, Kwan (2000).
} 


\section{International Journal of Social Sciences and Management Review}

the overnight reverse repurchase agreements $\left({ }^{i_{O N R R P}}\right)$. In December 2008, the target rate range between $0.00 \%$ and $0.25 \% .82$ Between 2008 and 2014, the Fed purchased a sizable amount of long-term securities (government securities and mortgage-backed securities). The reserves in the banking system went from $\$ 44.9$ billion (August 2007) to $\$ 2.842$ trillion (August 2014).83 Then, the reserves from limited became "ample" (plentiful, $v \pi \varepsilon \rho \mu \varepsilon \gamma \varepsilon \dot{\varepsilon} \theta \eta$, vं $\varepsilon \rho \mu \varepsilon \tau \rho \alpha)$. Also, the Fed implemented new monetary policy tools. The most significant was interest on reserves (IOR). Congress gave to Fed the authority to pay IOR in 2006,84 with starting date in 2011, but it started in October 2008. Interest on reserves applies to both required (IORR) and excess reserves (IOER ). This IOR is a bail out cost paying by taxpayers; consequently, an unfair and unethical "innovation".

Banks were before minimizing their holdings of excess reserves because ${ }^{i_{\text {IOER }}=0}$. Now, with $i_{\text {IOER }}>0$, banks have an incentive to hold more excess reserves. The ${ }^{i_{\text {IOER }}}$ became a tool to influence banks to hold more excess reserves at the Fed. The Fed has since that time the ${ }^{i_{\text {IOER }}}$ as a new tool for implementing monetary policy. Since November $2008, i_{\text {IORR }}=i_{\text {IOER }}$ and since March 26, 2020, the Fed abandoned the required reserves $\left(R_{R}=0\right) .85$ Then, IORR was made effectively irrelevant. The Fed shifted to an ample-reserves framework and reserve requirements are not anymore a tool of monetary policy. Thus, now, we have only $\operatorname{IOR}\left(i_{I O R}\right)$. The reserves are still remained "ample".86

When there is a large quantity of reserves in the banking system, as it is lately, Figure 7, the Fed can no longer influence the ${ }^{i}{ }_{F F}$ by making small changes in the supply of reserves $\left(R^{s}\right)$. Why we need all these non-borrowing reserves $\left(R^{*}\right)$ ? What is the reason of this enormous liquidity with the economy lockdown for more than a year and a very anemic $A D$ ? How we will control the bubble in the financial market and the creeping high inflation? The interest on reserves increases the national debt, too. The market manipulators and the oligopolistsmonopolists will start taking advantage of this situation. 87

${ }^{82}$ The Fed also implemented a number of credit and liquidity programs (which are mentioned in section II.2. above) early on in the Financial Crisis to support financial institutions and foster improved conditions in financial markets. These special programs expired or were closed to expire after some time.

${ }^{83}$ See, https://fred.stlouisfed.org/series/TOTRESNS

${ }^{84}$ This "innovation" took place under President George W. Bush and Ben S. Bernanke, who was sworn in on February 1, 2006, as chairman and a member of the Board of Governors of the Federal Reserve System. He also chaired the Federal Open Market Committee, the System's principal monetary policymaking body.

${ }^{85}$ See, "Reserve Requirements", https://www.federalreserve.gov/monetarypolicy/reservereq.htm

${ }^{86}$ In January 2019, the FOMC released a statement saying, it would continue to implement policy with ample reserves in the long run. See, Board of Governors of the Federal Reserve System. "Statement Regarding Monetary Policy Implementation and Balance Sheet Normalization.” Press release, January 30, 2019;

https://www.federalreserve.gov/newsevents/pressreleases/monetary20190130c.htm

More recently, in response to the COVID-19 pandemic, reserves have grown substantially. By May 2020, reserves expanded and stood above $\$ 3.218$ trillion, at a higher level than their peak during the aftermath of the Great Recession; on January 28, 2021, they were $\$ 3.135$ trillion, on February 23, 2021, they were $\$ 3.154$ trillion, on March 23, 2021, they became \$3.346 trillion and on June 22, 2021, they reached \$3.873 trillion.. https://fred.stlouisfed.org/series/TOTRESNS

${ }^{87}$ See, "GameStop day traders shook markets and hit hedge funds for billions. What has Wall Street learned?", https://markets.businessinsider.com/news/stocks/gamestop-saga-triggers-rethink-wall-street-short-seller-losses- 


\section{International Journal of Social Sciences and Management Review}

The Fed is using, now, its administered rates $\left({ }^{i_{I O R}}\right.$ and $\left.{ }^{i_{O N R R P}}\right)$ to influence the $i_{F F}$. The demand curve $\left(R^{d}\right)$ turns flat between the new administered rates at point $E_{1}$, Figure 7 , which helps to keep the $i_{F F}$ into the FOMC's target range $(0.00 \%-0.25 \%)$. With these enormous "ample" reserves, the Fed does not need to make daily $O M O$ ( $O M P$ or $O M S$ ), as it did before with the limited reserves to hit the $i_{F F}$ target. Now, small shifts of the supply curve $\left(R^{s}\right)$ have no effect on the ${ }^{i}$ FF .

The main tool for keeping the ${ }^{i_{F F}}$ on its target and driving the demand curve flat is the ${ }^{i_{I O R}}$. Banks invest their money short-term based on the interest rate and the risk. 88 They can

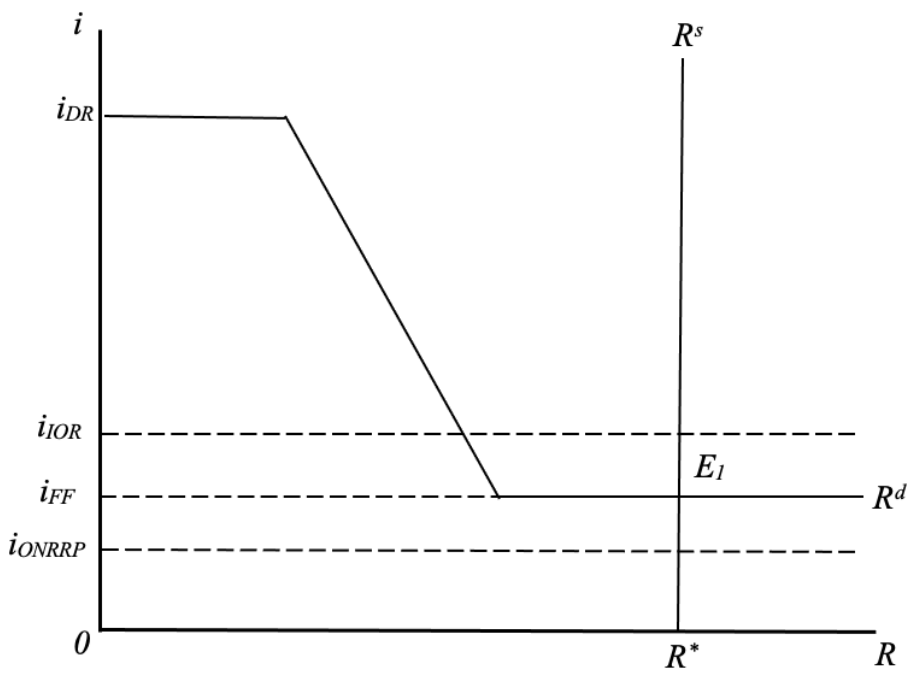

Note: ${ }^{i}=$ interest rates, ${ }^{i}{ }_{F F}=$ federal funds rate, ${ }^{i}{ }_{D R}=$ discount rate, $R=$ reserves, $R^{d}=$ demand for reserves, $R^{s}=$ supply of reserves, $R^{*}=$ non-borrowed reserves, $E$ = equilibrium $\left(R^{s}=R^{d}\right)$.

\section{Figure 7. Monetary Policy with Ample Reserves}

Invest in Treasury Bills $\left({ }_{R F}=0.04 \%\right.$, by offering loans to banks $\left({ }_{F F}=0.06 \%\right)$, or by depositing to the Fed $\left({ }^{i_{I O R}}=0.15 \%\right) .89$ Banks prefer to deposit their money to the Fed because $i_{I O R}$ is higher compared to the alternative S-T investments and it is also a safe overnight investment. (Sic). If the ${ }^{i_{F F}}$ were to fall very far below the ${ }^{i}$ IOR, banks would borrow in the federal funds market and deposit those reserves at the Fed, earning a profit

2021-1-1030021995. See also,” Reddit Jolts Activist-Short Hedge Funds Into ‘Adapt or Die' Mode”, https://www.bloomberg.com/news/articles/2021-01-27/reddit-jolts-activist-short-hedge-funds-into-adapt-or-die-mode 88 The short-term interest rates are closed to zero and the long-term ones very low since 2008. $i_{F F}=0.00 \%-0.25 \%, \quad i_{F F}^{e f f}=0.09 \%, \quad i_{R F}=0.08 \%, \quad i_{M M}=0.10 \%, \quad i_{D}=0.05 \%, \quad i_{D R}=0.25 \%$, $i_{5 Y C D}=0.48 \%, \quad i_{C M}=2 \%, i_{P}=3.25 \%, i_{15 Y M}=2.21 \%, i_{30 Y M}=2.77 \%, i_{2 Y G B}=0.12 \%, i_{5 Y G B}=0.42 \%$, $i_{10 Y G B}=1.03 \%, i_{30 Y G B}=1.79 \%$. See, Wall Street Journal, January 27, 2021.

${ }^{89}$ These rates are with June 30,2021 . The T-Bill rate in the secondary market was, $i_{R F}=0.02 \%$. 


\section{International Journal of Social Sciences and Management Review}

(arbitrage, $\pi_{A}$ ) on the difference $\left(\pi_{A}=i_{I O R}-i_{F F}\right)$. This arbitrage ensures that the ${ }^{i_{F F}}$ does not fall much below ${ }^{i}$ IOR .

$$
E X D_{F F} \Rightarrow i_{F F} \uparrow \text { and } \quad E X S_{\text {Re serves }} \Rightarrow i_{I O R} \downarrow
$$

Thus, when the Fed raises or lowers the ${ }^{i_{I O R}}$, the ${ }^{i_{F F}}$ moves up or down, too. Consequently, the Fed can keep the $i_{F F}$ into the target range set by the FOMC through adjustment of the $i_{I O R}$. The Fed sets the ${ }^{i_{I O R}}$ directly, so this interest rate serves as an effective monetary policy tool. Now, this $i_{I O R} 90$ is the primary tool used by the Fed for influencing the ${ }^{i}$ FF , Figure 7. The old tools were satisfying the same objective without charging citizens with any cost, as they have to pay, now, the IOR (bail out).91

In 2014, the FOMC announced that it will use the Overnight Reverse Repurchase Agreement Facility ( $O N R R P) 92$ to help control the $i_{F F}$. This facility is a form of $O M O$, where the Fed interacts with many nonbank financial institutions (large money market funds and government-sponsored enterprises).93 When one nonbank financial institution uses the $O N R R P$ facility, it deposits reserves at the Fed overnight receiving securities as collateral. The next day the transaction is "unwound";94 the Fed buys back the securities and the institution earns the ${ }^{i_{O N R R P}}$, which the Fed sets, on the cash it deposited at the Fed, Figure 7. This investment facility is a risk-free option and these institutions are willing to lend funds to this low rate, the ${ }^{i_{O N R R P}}$, but not lower. For this reason, the ${ }^{i_{O N R R P}}$ acts as a reservation rate and institutions can use it to arbitrage other short-term rates. Thus, the interest rate paid on ONRRP 95 transactions and it is below the ${ }^{i_{I O R}}$, acts like a floor for the ${ }^{i_{F F}}$ and serves as a supplementary policy tool by the Fed, Figure 7.

\subsection{VAR MODELS AND EMPIRICAL RESULTS OF MONETARY POLICY EFFECTIVENESS}

After the enormous bail out (IOR) and bail in $(\mathrm{rD}<0)$ cost to the taxpayers and depositors of the new monetary policy, we want to test the effectiveness of the monetary policy on the Fed'sobjective variables (monetary policy goals): stability of financial markets (DJIA), a stable real economy with maximum sustained output $\left(g_{G D P}\right)$, a moderate long-term interest

\footnotetext{
90 See, Board of Governors of the Federal Reserve System. "Interest on Required Reserve Balances and Excess Balances". https://www.federalreserve.gov/monetarypolicy/reqresbalances.htm

${ }^{91}$ See, Kallianiotis (2021a, pp. 53-57).

92 See, Board of Governors of the Federal Reserve System. "Overnight Reverse Repurchase Agreement Facility". https://www.federalreserve.gov/monetarypolicy/overnight-reverse-repurchase-agreements.htm.

${ }^{93}$ See, "What Is a Money Market Fund?", https://www.investopedia.com/investing/do-money-market-fundspay/ and "Government-Sponsored Enterprise (GSE)", https://www.investopedia.com/terms/g/gse.asp . See also, Federal Reserve Bank of New York, "Reverse Repo Counterparties". https://www.newyorkfed.org/markets/rrp counterparties.

${ }^{94}$ Unwind: To close out a relatively complicated investment position.

95 This $i_{\text {ON RRP }}=0.05 \%$ (July 2, 2021). See, https://fred.stlouisfed.org/series/RRPONTSYAWARD
} 


\section{International Journal of Social Sciences and Management Review}

Volume: 04, Issue: 04 "July - August 2021"

ISSN 2582-0176

rate $\left({ }^{\bar{i}_{L-T}}\right)$, price stability by maintaining a sustained low inflation rate, and maximum employment $\left(u=u^{N}\right)$. We run the following VAR model to test the efficiency and effectiveness of the monetary policy tools $\left({ }^{i e f F_{t}}, m b_{t}\right.$, and $\left.m_{t}\right)$ on these monetary goal variables. The results are shown in the Appendix, Tables A1, A2, and A3.

$$
\begin{aligned}
& \text { djia }_{t}=\alpha_{11} d j i a_{t-j}+\beta_{11} r g d p_{t-j}+\gamma_{11} i_{10 Y T B_{t-j}}+\delta_{11} p_{t-j}+\zeta_{11} u_{t-j}+c_{o}+\theta_{11} i_{F F_{t}}^{e f f}+\kappa_{12} m b_{t}+\lambda_{13} m_{t}+\varepsilon_{1 t} \\
& r g d p_{t}=\alpha_{21} d j i a_{t-j}+\beta_{21} r g d p_{t-j}+\gamma_{21} i_{10 Y T B_{t-j}}+\delta_{21} p_{t-j}+\zeta_{21} u_{t-j}+c_{o}+\theta_{21} i_{F F_{t}}^{e f f}+\kappa_{22} m b_{t}+\lambda_{23} m_{t}+\varepsilon_{2 t} \\
& i_{10 Y T B_{t}}=\alpha_{31} d j i a_{t-j}+\beta_{31} r g d p_{t-j}+\gamma_{31} i_{10 Y T B_{t-j}}+\delta_{31} p_{t-j}+\zeta_{31} u_{t-j}+c_{o}+\theta_{31} i_{F F_{t}}^{e f f}+\kappa_{32} m b_{t}+\lambda_{33} m_{t}+\varepsilon_{3 t} \\
& p_{t}=\alpha_{41} d j i a_{t-j}+\beta_{41} r g d p_{t-j}+\gamma_{41} i_{10 Y T B_{t-j}}+\delta_{41} p_{t-j}+\zeta_{41} u_{t-j}+c_{o}+\theta_{41} i_{F F_{t}}^{e f f}+\kappa_{42} m b_{t}+\lambda_{43} m_{t}+\varepsilon_{4 t} \\
& u_{t}=\alpha_{51} d j i a_{t-j}+\beta_{51} r g d p_{t-j}+\gamma_{51} i_{10 Y T B_{t-j}}+\delta_{51} p_{t-j}+\zeta_{51} u_{t-j}+c_{o}+\theta_{51} i_{F F_{t}}^{e f f}+\kappa_{52} m b_{t}+\lambda_{53} m_{t}+\varepsilon_{5 t}
\end{aligned}
$$

where, $d j i a_{t}=\ln$ of U.S. Dow Jones Industrial Average Index, ${ }^{r g d p_{t}}=\ln$ of U.S. real GDP, $i_{10 Y B_{t}}=$ U.S 10-Year Treasury Bonds Rate, $p_{t}=\ln$ of U.S. CPI, ${ }^{u_{t}}=$ U.S. unemployment rate, $i_{F F_{t}}^{e \text { eff }}=$ U.S. effective federal funds rate, ${ }^{m b_{t}}=\ln$ of U.S. monetary base, ${ }^{m}{ }_{t}=\ln$ of U.S. money supply (M2).

For the period 2008:12 to 2015:11 (Table A1), the monetary policy was completely ineffective on financial market (DJIA), on economic growth (GDP), on long-term interest rate $\left({ }^{i_{10 Y T B}}\right)$, and on price level $\left({ }^{p}\right)$. The monetary policy $\left({ }^{i_{F F}}\right)$ was statistically significant on unemployment $\left(1.963^{* * *}\right)$. A reduction of $i_{F F}^{e f f}$ was reducing unemployment. Also, the $m b$ was significant on unemployment rate $(0.952 *)$. The increase in monetary base $(\mathrm{mb})$ unfortunately, increased also the unemployment $\left({ }^{u}\right)$.

From 2015:12 to 2019:06 (Table A2), the monetary policy is a little more effective. The $m b$ is statistically significant $\left(0.501^{*}\right)$ on $D J I A$ and the same holds for the $\mathrm{m}\left(1.646^{* * *}\right)$. Then, the bubble is growing. The ${ }^{i e f f}$ is significant $\left(0.028^{* * *}\right)$ on $G D P$; also significant are the $m b$ $\left(-0.035^{* *}\right)$ and the money supply, $\mathrm{m}\left(0.068^{*}\right)$. The money supply is significant $\left(0.078^{* *}\right)$ on $\mathrm{p}$, too; prices are going up; no effects on L-T interest rate or unemployment. ( $\left.M^{s} \uparrow \Rightarrow D J I A \uparrow, i_{F F} \downarrow \Rightarrow G D P \downarrow, M B \uparrow \Rightarrow G D P \downarrow, M^{s} \uparrow \Rightarrow G D P \uparrow, M^{s} \uparrow \Rightarrow P \uparrow\right)$.

The results of the VAR for the extended period (1995:01-2008:11) are shown in Table A3 and we observe that monetary policy has not any significant effect on ${ }^{i_{10 Y T B}}$. The monetary policy has significant effects on market $(M B \uparrow \Rightarrow D J I A \downarrow)$, on the GDP ( $\left.M^{s} \uparrow \Rightarrow G D P \uparrow\right)$, on price level $\left(M B \uparrow \Rightarrow P \downarrow \quad\right.$ and $\left.\quad M^{s} \uparrow \Rightarrow P \uparrow\right)$ and on unemployment ( $\left.i_{F F} \uparrow \Rightarrow u \downarrow, M B \uparrow \Rightarrow u \uparrow, M^{s} \uparrow \Rightarrow u \uparrow\right)$. 


\section{International Journal of Social Sciences and Management Review}

Volume: 04, Issue: 04 "July - August 2021"

ISSN 2582-0176

Thus, the social cost is the bail in cost to depositors, the bail out cost to taxpayers, the bubble in the stock market, the reduction in output, the increase of price level, but no effect on employment. Finally, we can test correlation and causality between the monetary policy tools $\left({ }^{i}{ }_{F F_{t}}^{e f f}, m b_{t}\right.$, and $\left.m_{t}\right)$ and the objective variables ( ${ }^{2 j i a_{t}},{ }^{r g d p_{t}},{ }^{i_{10 Y T B_{t}}}, p_{t}$, and $\left.{ }^{u_{t}}\right) .96$ They show (ZIRR: 2008:12-2015:11) that the reduction of ${ }^{i_{F F}}$ and the increase in $m b$ and money supply ( $m_{t}$ ) cause bubbles in the financial market, inflation, growth in production and employment, and reduction of the L-T interest rates. During the (NR: 2015:12-2020:12) the results are mixed; there are not significant effects on our objective variables.

Federal Reserve officials signaled plans to keep interest rates near zero for years to come and said they were studying how to provide more support to a U.S. economy battered by the coronavirus and related shutdowns. "We are strongly committed to using our tools to do whatever we can and for as long as it takes to provide some relief and stability." Fed Chairman Jerome Powell said on June 10, 2020 at a virtual news conference after a two-day policy meeting. 97 Thus, the unethical bail in and bail out will continue for some more years, due to this latest healthcare, financial, economic, and the worst of all, the election crisis and the division of the country to two nations through a "war" against American traditional value system. We also want to see if there are any social benefits from this monetary policy.

Monetary policy's social benefits can be detected by testing the effect of this policy on the components of aggregate demand $(A D)$, on consumption $(C)$, on investment $(I)$, on trade account $(T A=X-M)$, on exchange rate $\left({ }^{e}\right)$, and on the $R G D P$. Thus, another VAR can test the effectiveness of policy tools $\left({ }^{i}{ }^{e f f} F_{t}, m b_{t}\right.$, and $\left.{ }^{m_{t}}\right)$ on our social benefits, as follows:

$$
\begin{aligned}
& c_{t}=\alpha_{11} c_{t-j}+\beta_{11} i_{t-j}+\gamma_{11} t a_{t-j}+\delta_{11} e_{t-j}+\zeta_{11} r g d p_{t-j}+c_{o}+\theta_{11} i_{F F_{t}}^{e f f}+\kappa_{12} m b_{t}+\lambda_{13} m_{t}+\varepsilon_{1 t} \\
& i_{t}=\alpha_{21} c_{t-j}+\beta_{21} i_{t-j}+\gamma_{21} t a_{t-j}+\delta_{21} e_{t-j}+\zeta_{21} r g d p_{t-j}+c_{o}+\theta_{21} i_{F F_{t}}^{e f f}+\kappa_{22} m b_{t}+\lambda_{23} m_{t}+\varepsilon_{2 t} \\
& t a_{t}=\alpha_{31} c_{t-j}+\beta_{31} i_{t-j}+\gamma_{31} t a_{t-j}+\delta_{31} e_{t-j}+\zeta_{31} r g d p_{t-j}+c_{o}+\theta_{31} i_{F F_{t}}^{e f f}+\kappa_{32} m b_{t}+\lambda_{33} m_{t}+\varepsilon_{3 t}
\end{aligned}
$$

$$
\begin{aligned}
& e_{t}=\alpha_{41} c_{t-j}+\beta_{41} i_{t-j}+\gamma_{41} t a_{t-j}+\delta_{41} e_{t-j}+\zeta_{41} r g d p_{t-j}+c_{o}+\theta_{41} i_{F F_{t}}^{e f f}+\kappa_{42} m b_{t}+\lambda_{43} m_{t}+\varepsilon_{4 t} \\
& r g d p_{t}=\alpha_{51} c_{t-j}+\beta_{51} i_{t-j}+\gamma_{51} t a_{t-j}+\delta_{51} e_{t-j}+\zeta_{51} r g d p_{t-j}+c_{o}+\theta_{51} i_{F F_{t}}^{e f f}+\kappa_{52} m b_{t}+\lambda_{53} m_{t}+\varepsilon_{5 t}
\end{aligned}
$$

Where, ${ }^{c_{t}}=\ln$ of USPCE (U.S. personal consumption expenditures), ${ }^{i_{i}}=\ln$ of USFPI (U.S. fixed private investment), ${ }^{t a_{t}}=\ln$ of USTA (U.S. trade account), ${ }^{e_{t}}=\ln$ EUS (US/EU spot rate, $\$ / €),{ }^{r g d p_{t}}=\ln$ of U.S. real GDP, ${ }^{i_{F F_{t}}^{e f f}}=$ U.S. effective federal funds rate, ${ }^{m b_{t}}=\ln$ of U.S. monetary base, ${ }^{m} t=\ln$ of U.S. money supply (M2).

\footnotetext{
96 These results are available from the author upon request.

97 See, "Fed Officials Project No Rate Increases Through 2022". https://www.wsj.com/articles/fed-debateshow-to-set-policy-for-the-post-pandemic-economy-11591781402
} 


\section{International Journal of Social Sciences and Management Review}

Volume: 04, Issue: 04 "July - August 2021"

ISSN 2582-0176

Then, we estimate of the VAR, eq. (14) and we look at the effects of monetary policy on social benefits. Table A4 (2008:12-2015:11) shows some significant effects on consumption, investment, trade, exchange rate, and production $\left.M^{s \uparrow} \Rightarrow C \uparrow, M^{s} \uparrow \Rightarrow I \uparrow, M^{s} \uparrow \Rightarrow T A \uparrow, M^{s} \uparrow \Rightarrow e \downarrow(\$ \uparrow), i_{F F} \downarrow \Rightarrow G D P \downarrow\right)$. Table A5 (2015:122020:12) gives some questionable significant effects, too $\left(M B \uparrow \Rightarrow C \downarrow, M^{s} \uparrow \Rightarrow C \uparrow\right)$, ( $i_{F F} \downarrow \Rightarrow I \downarrow, M B \uparrow \Rightarrow I \downarrow, M^{s} \uparrow \Rightarrow I \uparrow, i_{F F} \downarrow \Rightarrow T A \uparrow, i_{F F} \downarrow \Rightarrow e \downarrow(\$ \uparrow), M B \uparrow \Rightarrow e \uparrow(\$ \downarrow)$,

and $M B \uparrow \Rightarrow G D P \downarrow)$. Table A6 (1999:03-2020:12) shows significant effects on consumption, investment, trade account, and production. When, $\left(i_{F F} \uparrow \Rightarrow C \uparrow, M B \uparrow \Rightarrow C \uparrow, M^{s} \uparrow \Rightarrow C \uparrow\right)$, also $\left({ }_{F F} \uparrow \Rightarrow I \uparrow, M B \uparrow \Rightarrow I \uparrow\right)$, further $\left({ }_{F F} \uparrow \Rightarrow T A \uparrow, i_{F F} \uparrow \Rightarrow G D P \uparrow\right)$. There is some effectiveness of monetary policy and are some social benefits on consumption and investment, but no benefits on production. Also, some mixed results are shown after 2015 that the benefits of monetary policy are negative. In addition, we test the correlation and causality98 for the (ZIRR: 2008:12-2015:11) between the policy tools and objective variables. There are some improvements in consumption, investment, growth, and appreciation of the dollar; the trade account was deteriorated. With the (NR: 2015:12-2020:12), there is only a little improvement in consumption and investment, but nothing else.

Another inefficiency is the interest rate on deposits, which are close to zero since December $2008\left({ }_{D}=0.05 \%, i_{6 M C D}=0.30 \%\right.$, and $\left.i_{12 M C D}=0.48 \%\right)$ and the real (savings) deposit rate is negative (-4.95\% with the official inflation or $-12.95 \%$ with the SGS inflation), an enormous bail in cost. In other words depositors have to pay their banks to keep save the deposits in the banks. But, are these deposits save? We saw 50\% bail in of deposits in Cyprus during the European debt crisis.99 (Sic). Many foreign central banks reduced their interest rates on deposits held by banks at them to negative.100 With our negative real deposit rates, the Fed was expecting to stimulate the economy by encouraging banks to lend out the deposits they were having and to increase business investments and households spending; but the only effect was the increase in the stock prices (bubbles) and the enormous unfair bail in cost of the depositors. There was no or very little expansionary effect on our GDP growth.

Banks keep all these deposits as reserves and receive IOR by the Fed (bail out cost to taxpayers) or invest them to securities, they do not lend them out because there is no demand for loans and it is also risky. Actually, these negative real interest rates became contractionary because banks cut back on lending, too.101 It is, actually, a disincentive to save. This policy is not effective in stimulating investment, spending, growth, and employment. Also, it is ethically questionable. The results show that the target rates of our central bank (Fed) are

\footnotetext{
98 These results are also available from the author.

${ }^{99}$ See, "Bank of Cyprus depositors lose $47.5 \%$ ",

https://www.usatoday.com/story/money/business/2013/07/29/bank-of-cyprus-depositors-lose-savings/2595837/

. See also, "Failing banks, bail-ins, and central bank independence: Lessons from Cyprus", https://voxeu.org/article/bank-bail-ins-lessons-cypriot-crisis

${ }_{100}$ The ECB Deposit Facility rate is $-0.50 \%$ since September 18, 2019. See, "Key ECB interest rates", https://www.ecb.europa.eu/stats/policy and exchange rates/key ecb interest_rates/html/index.en.html

101 The deposit rates must be positive and $1 \%$ above the expected inflation rate, $\left(i_{D}=\pi^{e}+1 \%\right)$. The current policy is unfair, contractionary, and risky.
} 


\section{International Journal of Social Sciences and Management Review}

Volume: 04, Issue: 04 "July - August 2021"

ISSN 2582-0176

very low. The empirical results and all the tests and rules reveal that these monetary policies do not promote social welfare, because its social benefits are less than its social cost.

\subsection{POLICY EFFECTIVENESS, EFFICIENCY, AND RISK}

The financial crisis of 2007-2009 revealed to us how costly the bubbles are in the financial markets. Their bursting severely disrupted the financial system,102 leading to recession, high unemployment, home foreclosures, etc. What should the Fed do about these bubbles? Monetary policy needs to respond to asset prices in order to stabilize the economy. The monetary policy should control the growth of possible developing asset-price bubbles to minimize later damage to the economy, when these bubbles burst. The question is for the central bank: Is its policy leaning against financial bubbles or is it cleaning up after the bubble burst? Are these bubbles driven by over optimistic expectations ("irrational exuberance") or by enormous credit (money supply and low margin requirements)?

The easy money policy for so many years provided this liquidity, which was used to purchase financial assets and thereby raise their prices. The only 50\% margin requirements further increases the demand for these assets and their prices are going up. This credit boom drives assets prices even higher and the bubble is generated much easier; stock prices are raised above their fundamental values. When these bubbles are burst, loans fall, the demand for assets falls further and their prices drop even more, and economic activity falls, too; then, financial institutions are collapsing. The unfortunate taxpayers are forced to bail them out. Thus, this extreme easy policy is inefficient and risky.

The bubbles from irrational exuberance are smaller and less risky for the financial market. For example, these tech-stock or dot-com or internet bubbles in 1990s103 caused less trouble. Then, big bubbles are created from the enormous liquidity and the greediness ("greed \& fear") of the market participants. These are the reasons that prices of financial assets are getting out of line with fundamentals. At this point the Fed has to stop increasing the money supply by increasing the interest rate, eq. (7). This increase in interest rate must be gradual; otherwise the higher interest rate can cause the bursting of the bubbles. The bubble creation by money supply can be seen with the following correlations $(\rho)$ and causalities: From 2008:12-2015:11, the $\rho_{m, d j a}=+0.943$ and $\quad m \Rightarrow \operatorname{djia}\left(F=4.033^{* *}\right)$; and from 2015:12-2020:12, this correlation was, $\rho_{m, d j i a}=+0.777$. The monetary policy has to prevent bubbles because it will be difficult to control them. The Fed might not need to increase federal funds rate to control bubbles because it can harm the economy; but it can increase the margin requirements

\footnotetext{
102 The DJIA was 14,164.53 (October 9, 2007) and fell to 6,547.05 (March 9, 2009); a decline by 7,617.48 points or $-53.78 \%$. See, Kallianiotis (2015, p. 33).

103 The dotcom bubble, also known as the internet bubble, was a rapid rise in U.S. technology stock equity valuations fueled by investments in internet-based companies during the bull market in the late 1990s. During the dotcom bubble, the value of equity markets grew exponentially, with the technology-dominated NASDAQ index rising from under 1,000 to more than 5,000 between the years 1995 and 2000. In 2001 and through 2002 the bubble burst, with equities entering a bear market. See, https://www.investopedia.com/terms/d/dotcombubble.asp

See also, "4 Charts That Show This Tech Boom Is No Dot-Com Bubble",

https://www.capitalgroup.com/advisor/ca/en/insights/content/articles/tech-boom-no-dot-com-bubble.html
} 


\section{International Journal of Social Sciences and Management Review}

(i.e., to $r_{m}=90 \%$ ) and reduce the demand for securities. This instrument keeps the stock prices at a normal growth independent from the credit-driven and "irrational exuberance" bubbles. The bubbles can be controlled not only with monetary policy, but with financial market regulations. The low interest rate of the Fed from 2002 to 2005 and from 2008 to present is followed by excessive risk taking. Then, a too easy monetary policy promotes financial instability (bubbles) and it has also generated a liquidity trap.104

However, if on a particular day, the demand for withdrawals from the bank is increasing, the bank has to scramble to come up with cash from its reserves. But, if it does not have the reserves, the bank finds itself in trouble. When one bank finds itself having to shut its doors because it cannot meet the demand for liquidity, or too many bad (red) loans, customers of all the other banks get scared that their bank might be in the same position. Then, the whole banking system, which depends on the depositors' confidence, is under siege (run on the bank).105 Another problem can be the stability of monetary policy. What the Federal Reserve wants, it is to create a steady demand for reserves, so that it can provide more reserves (by reducing the ${ }^{r_{R}}$ ); when it wants to allow banks to create more loans, and increase the money supply. It provides fewer reserves when it wants to put banks in the position of having to call in loans and shrink the money supply (tight money). By having a mandatory reserve requirement, the Fed was creating a stable demand for reserves, which allowed it then to manipulate the money supply with some regularity and security. Now, these perspectives have been lost, due to the mew monetary policy tools and the zero reserve requirement $(\mathrm{RR}=0)$.

If we allow banks to decide by themselves (another deregulation) how much they want to hold as reserves, they are going to hold the amount of reserves that minimizes the risk of not having money to give their depositors when they ask for withdrawals. The question is now. Is it good to let the market solve social economic problems rather, than regulators with their law? Banks maximize their objective ignoring the risk because the government will bail them out, as it happened in 2008 that cost to the taxpayers trillions of dollars. 106 The government passaged into U.S. law, on October 3, 2008, a $\$ 700$ billion financial-sector rescue plan that was the latest in the long history of U.S. government bailouts. The 2020 COVID -19 pandemic

\footnotetext{
104 This is the case of a liquidity trap that is a contradictory economic situation in which interest rates are very low, rendering monetary policy ineffective. First, it described by economist John Maynard Keynes. During a liquidity trap, consumers choose to avoid bonds and keep their funds in cash savings because of the prevailing belief that interest rates could soon rise (which would push bond prices down). Because bond prices have an inverse relationship to interest rates, many consumers do not want to hold an asset with a price that is expected to decline. At the same time, central bank efforts to spur economic activity are hampered as they are unable to lower interest rates further to incentivize investors and consumers.

${ }^{105}$ A bank run (also known as a run on the bank) occurs when many depositors withdraw their money from a bank, because they believe the bank may cease to function in the near future. In other words, it is when, in a fractional-reserve banking (or zero reserves, today) system (where banks normally only were keeping a small proportion of their assets as cash, $r_{R}=10 \%$ ), numerous depositors withdraw cash from their deposit accounts with a financial institution at the same time, because they believe that the financial institution is, or might become, insolvent.

106 This bail out money was offered as bonuses to inefficient executives. (Sic). "Banks that are getting taxpayer bailouts awarded their top executives nearly $\$ 1.6$ billion in salaries, bonuses, and other benefits last year, an Associated Press analysis reveals". See, https://www.cbsnews.com/news/16b-of-bank-bailout-went-to-execs/
} 


\section{International Journal of Social Sciences and Management Review}

Volume: 04, Issue: 04 "July - August 2021"

ISSN 2582-0176

led to multi-trillion dollar bailouts of both businesses and individuals in America and similar policies have been taken across the globe. To date, over $\$ 4$ trillion has been deployed to keep the economy running in the face of this suspicious Chinese pandemic, the Wuhan coronavirus.107 Regulators (Fed, FDIC, comptroller of the currency, etc. ) must concern about the systemic nature of risk in the banking system and should fear about policy, which is not being conducted in an orderly and reliable way, meaning that reserve requirements should exist to control $M B$ and $M^{s}, 108$ together with higher margin requirements (since 1974, it is $\left.r_{m}=50 \%\right) 109$ and many other regulations.

Also, the largest the velocity of money, the faster the money circulates and more income is generated because every time the money changes hands, it becomes income for another person. Thus, the easy money policy $\left(0.00 \%<i_{F F}<0.50 \%\right)$ from 2008 to 2017110 and the new monetary policy instruments ( $I O R_{t}, Q E, R_{R}=0, i_{O N R R P}$, and ample reserves) did not affect the real economy; it just lowered the velocity of money,111 increased the market risk (bubbles), augmented the expectations for a creeping inflation, and generated enormous negative real returns. People did not spend their money, but the Fed was subsidizing the financial sector by creating a new bubble, which was burst with the "innovative" Chinese coronavirus (the biological WWIII). The federal funds went back to zero (March 15, 2020),112 and the same cycle will be repeated. This liquidity trap (zero interest rate), does not allow the Fed to influence monetary policy, because it cannot lower the interest rate further to stimulate the economy. Also, it has become a real trap for the risk-averse depositors that have a closed to zero deposit rate since 2008.113 Monetary policy has become ineffective.114 Interest rate must be consistently above zero in our non-ideal (imperfect) world (because

107 See, "US Government Binancial Bailouts",

https://www.investopedia.com/articles/economics/08/government-financial-bailout.asp . Also, "Emergency Economic Stabilization Act of 2008",

https://en.wikipedia.org/wiki/Emergency_Economic_Stabilization_Act_of_2008 . Further, "Here's what's in the \$2 trillion stimulus package — and what's next", https://www.politico.com/news/2020/03/25/whats-in-stimuluspackage-coronavirus-149282 . A Chinese virologist, Dr. Li-Meng Yan said: "This virus came from a Wuhan Lab and it was intentional." (Fox News, 11/20/2020). A second bill of \$1.9 trillion was signed by Biden. (Sic). https://www.nbcnews.com/politics/congress/what-s-1-9-trillion-covid-bill-biden-just-signed-n1260719 . There was a third bill, too. See, "FACT SHEET: The American Rescue Plan Will Deliver Immediate Economic Relief to Families", https://home.treasury.gov/news/featured-stories/fact-sheet-the-american-rescue-plan-willdeliver-immediate-economic-relief-to-families

${ }^{108}$ See,

file:///C:/Users/JK/AppData/Local/Microsoft/Windows/Temporary\%20Internet\%20Files/Content.IE5/51F9Y8A K/8517.pdf . See also, https://fred.stlouisfed.org/series/BOGMBASE..

See further, https://fred.stlouisfed.org/series/M2

${ }^{109}$ See, "Margin Requirements as a Policy Tool?", https://www.frbsf.org/economicresearch/publications/economic-letter/2000/march/margin-requirements-as-a-policy-tool/

110 "Federal Funds Target Range (FFR)", See, https://fred.stlouisfed.org/series/DFEDTARU

For the "Effective Federal Funds Rate (EFFR)", see, https://fred.stlouisfed.org/series/EFFR

111 See, Kallianiotis (2021a).

${ }^{112} \mathrm{See}$, https://apps.newyorkfed.org/markets/autorates/fed\%20funds

${ }^{113}$ With an inflation for February $2020, \pi=2.3 \%$, the depositor, instead of receiving interest, he was paying to his bank $\left(r_{D}=i_{D}-\pi=0.05 \%-2.3 \%=\right)-2.25 \%$ p.a. to keep his deposits. https://tradingeconomics.com/unitedstates/inflation-cpi . See, footnote 55 .

${ }^{114}$ See, Kallianiotis (2019a, b, c, 2020a, b, c, and d, and 2021a). 


\section{International Journal of Social Sciences and Management Review}

$\pi^{e}>0$ and Risk $>0$ ). Fiscal policy is mostly effective, if the government is not very corrupted, because it is independent from interest rate. Also, trade policy (exchange rate, tariffs, import taxes, quotas, etc.) is inevitably necessary because is making the domestic economy self-sufficient and independent from the foreign economies. 115

The enormous money supply $(M 2) 116$ increases the prices $(P)$ and real wages $\left({ }^{w / P}\right)$ are falling, but the workers have no choice and continue to work and they are happy that they are employed or they receive the generous unemployment compensation from the government. This is the "money illusion". Firms sell their products to higher prices and make more profits, so they expand production and hire more workers at the same nominal wage (w), but in the U.S. workers prefer to stay home and get the welfare benefits (UC). (Sic). A Phillips curve117 exists in the short run. Workers cannot ask for higher nominal wages in our globalized and open borders world because firms start hiring illegal immigrants at very low wages or they do outsourcing. 118

Economists have different philosophical views about the policy used to stimulate the economy. Thus, politicians choose as advisors the economists, who suit their ideology. Markets, businesses, and institutions exist to serve the people and to contribute to social welfare and not to care only for their interest, otherwise we do not need them. We need an ideal and humane economic system with zero unemployment, zero inflation, zero trade deficits, zero government deficit, zero households deficit; public (monetary) policies that make no even a single individual worse off of what he was before and a maximization of social welfare for every citizen. But these conditions do not exist; then, the markets, the institutions, and the policy makers are not efficient and need to be regulated.

Fed reduced the federal funds rate (on December 16, 2008) to $0.25 \%$ (quantitative easing) 119 to affect positively (increase) the money supply. Really, the money supply has increased drastically ( $M B$ from $\$ 850.8$ billion in September 2007 became $\$ 4,149.505$ billion in September 2014, in January 2021, it reached \$5,247.900 billion, at the end of March 2021, it was $\$ 5,446.900$ billion, and reached $\$ 6,041.900$ billion on June 22, 2021) and continues to

115 "The economics profession [with their artificial theories, heroic assumptions, and wrong philosophies

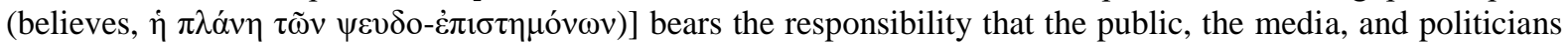
are ill informed about real world economics." See, Komlos (2019b, p. 14).

${ }^{116}$ Money supply ( $M 2$ ) from $\$ 7,459.6$ billion (1/14/2008) became \$17,234.8 billion (4/30/2020), a growth of $131.042 \%$ (10.697\% p.a.), and reached \$18,318.2 billion (7/20/2020). See, https://fred.stlouisfed.org/series/M2 . On $3 / 25 / 2021$, it was $\$ 19,669.8$ billion and on $6 / 22 / 2021$ in reached $\$ 20.278 .4$ billion. See, https://fred.stlouisfed.org/series/WM2NS . Thus, the inflation is double digits, $\pi^{\mathrm{e}}=10 \%$.

${ }_{117}$ See, footnote 52 for the Phillips curve and its estimation.

118 “AT\&T CEO Randall Stephenson promised to create "7,000 good jobs for the middle class" after Trump's tax cut was passed, yet the company has been laying off thousands of workers and shipping those jobs overseas to India, China and other countries where workers can be paid less than $\$ 2$ [ $\$ 0.50$ in China and $\$ 0.10$ in India] an hour. This is what a rigged economy is all about." See, https://www.techdirt.com/articles/20191211/10503943556/att-said-trump-tax-cuts-would-create-thousands-jobsinstead-atts-laying-off-thousands.shtml

${ }^{119}$ Fed Funds Rate History with Its Highs, Lows, and Charts: How the Benchmark Has Changed Through History, https://www.thebalance.com/fed-funds-rate-history-highs-lows-3306135 . See, also, https://www.federalreserve.gov/monetarypolicy/openmarket.htm 


\section{International Journal of Social Sciences and Management Review}

Volume: 04, Issue: 04 "July - August 2021"

ISSN 2582-0176

grow.120 At a given price level, it was expected the aggregate demand ( $A D$ ) to rise. More money in the economy and closed to zero interest rate was expected to equate money supply with money demand. This lower interest rate (cost of capital) and the ample reserves could stimulate more investment and consumption. More investment and consumption require a higher level of GDP for spending balance. All these should shift aggregate demand to the right and the economy will improve. But, the aggregate demand did not rise because people are unemployed and their debts are enormous. The cost of capital (loans' rate) went down and the banks had all this liquidity generated by the Fed, but people did not borrow; they did not have the required qualifications to borrow and they did not want more debt. Then, individuals' demand fell and firms' investment declined, too, because in an economy demand creates supply $(A D \Rightarrow A S)$ and not the opposite. Actually, consumption and investment fell and aggregate demand decreased drastically, which affected negatively production, output, and employment. But, banks are receiving interest (IOR)121 from the Fed (paid by taxpayers) on their excess reserves (non-disposable funds) and on the required reserves (before their abolition).122 These expansions benefit only speculators through financial markets (Figure 8).

The Great Recession (2008)123 vs the Great Destruction (2020)124 followed the subprime mortgage bubble and the stock market bubble with a substantial decline in income, increases in unemployment, a rise in foreclosures, and maximized the suffering of the U.S. people. The investment was cut and the aggregate demand declined. This was a deep recession. In September 2008, the big investment banks disappeared and the poor taxpayers bailed out the Wall Street, but there were neglected the structural problems of the U.S. economy. The Fed and the Treasury tried to help the economy, but the country continued to have the same structural problems, the immense trade deficit, the foreign dependence, the national debt and private debts, the deteriorating infrastructure, part time and half time work, students debt, and a government that could not overcome the lobbies and introduced a new doctrine to control the free speech, the elusive "politically correct", and to finance and maintain so many unnecessary conflicts wars around the world. The Obama administration did not make any structural changes, except of deepening the division among people and institutionalizing

${ }^{120}$ A growth of the MB by $\$ 3,298.705$ billion or $387.718 \%$ (55.39\% per annum). Then, if inflation is a monetary phenomenon (according to Monetarist School), we must have a double digits inflation.

https://fred.stlouisfed.org/series/BOGMBASE/

${ }^{121}$ See, Kallianiotis (2019a, b, c and 2020b and c).

${ }^{122}$ Required reserves were abolished on March 26, 2020. See, Kallianiotis (2020c). See, also, https://www.federalreserve.gov/monetarypolicy/reservereq.htm

123 The causes of the latest global financial crisis (2008) are: (1) Greenspan's Ideology, (2) The Financial Innovations, (3) The Rise of the Shadow Banking System, (4) The Neglect of Systemic Risk, (5) Groupthink rendered Greenspan's view politically correct, (6) The Dot-Com Bubble, (7) The lowering of Interest Rates, (8) Credit Rating Agencies, (9) Excessive Faith in Quantitative Finance, (10) Endemic Trade Deficits, (11) Easy Credit, (12) Banks Lowered Underwriting Standards, (13) Expansion of Subprime Lending, (14) Predatory Lending, (15) Bubble in House Prices, (16) The Illusion of Tranquility was Deceptive, (17) Deregulation, (18) High Debt Burden, (19) Financialization, (20) Herd Mentality, (21) Mispricing of Risk, (22) Out of control Leverage, (23) Globalization, (24) Moral Hazard, (25) Lack of Historical Perspective, (26) Hubris was ubiquitous, (27) Culture, (28) Inequality of Income, (29) Corporate Governance, (30) Revolving Door (executive in finance were appointed to government position), and (31) Media (fake news). See, John Komlos, Foundations of Real-World Economics, Second Edition, Routledge, 2019b, pp. 243-252.

124 See, Kallianiotis (2020d). 


\section{International Journal of Social Sciences and Management Review}

Volume: 04, Issue: 04 "July - August 2021"

ISSN 2582-0176

liberalism; the Trump administration tried for four years to revise and restructure this economic setback and affliction, but he was confronted with all the implausible means that the establishment can invent, from impeachments to the Chinese coronavirus; with the current unique administration in the U.S. political history, all signs for improvement are negative. This recent crisis of 2020, with the suspicious coronavirus, the health problems, the hundred thousands of deaths, the extended lockdown of businesses, the shutdown of the economy, the stay-at-home orders, it destroyed the small

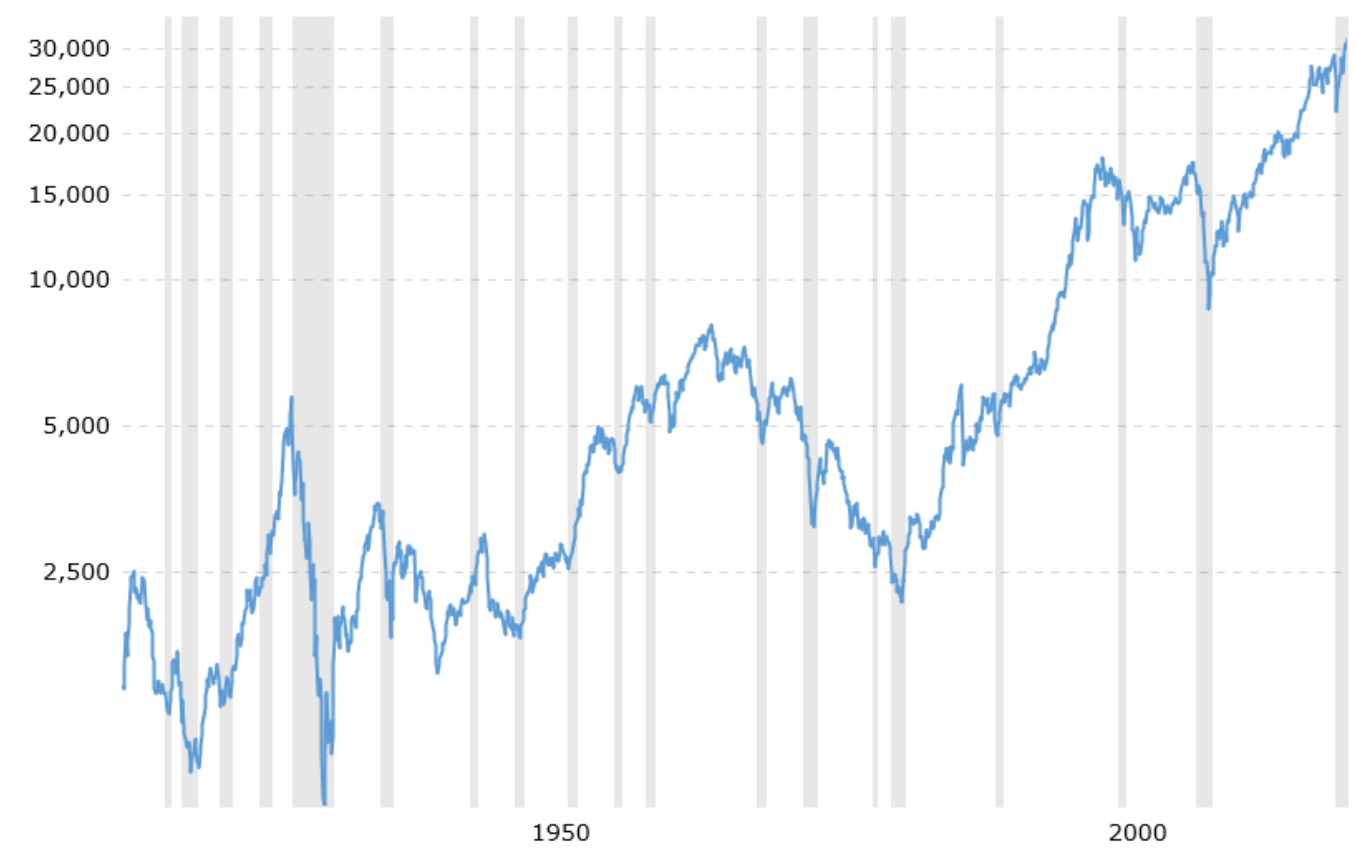

Note: Dow Jones - DJIA - 100 Year Historical Chart

Source: Macrotrends https://www.macrotrends.net/1319/dow-jones-100-year-historical-chart

\section{Figure 8. The DJIA Index}

Businesses and will help only the monopolists; it affected negatively Universities and education in general. It led the civil liberties at risk and had unexpected consequences of this ongoing isolation (drugs, alcohol, psychological problems, violence, divorces, and crimes). Then, it "came" (they allowed) the civil unrest, the manipulation of the public opinion by the liberal media, the riots, violent, lootings, chaos, lawlessness, destruction, division, and the election irregularities. Further, some experimental vaccines appeared in a few months, which have increased the uncertainty, deaths, generating new variants, and have raised many ethical questions among people.125 Unfortunately, this new crisis it seems as the worst in human history, 126 a global Great Destruction 127 and it is impossible the current monetary policy to generate soon any recovery.

\footnotetext{
125 These vaccines were supposed to help us get back to normal, but they do not do anything. Dr. Fauci said,

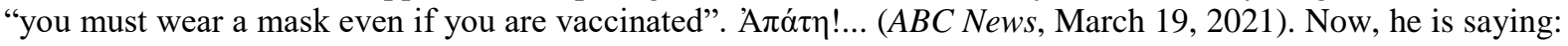
"Vaccines must be more mandated", CNN News, 7/12/2021.

126 And in the U.S. this crisis has political ramifications; it is manipulated and utilized by the liberals to go against the conservatives. Now, it comes to my mind what one of my professors in Microeconomics was telling us (his students) 42 years ago: "A politician has only one interest, to be reelected, nothing else; he does not care
} 


\section{International Journal of Social Sciences and Management Review}

\subsection{CONCLUDING REMARKS}

When the Fed wants to reduce the interest rate, it injects reserves into the system by conducting OMP of bonds, which cause their prices to increase and their interest rates to fall, at least in the short-term. When the Fed wants to raise interest rates, it withdraws reserves from the system by selling bonds, OMS; therefore, it depresses their prices and raises their interest rates. From the long-run perspective, if the Fed purchases securities (OMP), which is an expansionary monetary policy with low interest rates and huge liquidity, inflation will rise, so interest rate will rise in the long-run (Fisher effect: $i_{t}=r_{t}+\pi^{e}$ ). Contractionary monetary policy will lower inflation in the long-run and the long-run interest rates will fall.

The objective of monetary policy is to smooth the large fluctuations of the business cycle. There are debates rages on whether monetary policy can smooth business cycles 128 or not. A central conjecture of Keynesian Economics129 is that the central bank can stimulate aggregate demand $(A D)$ in the short run, because a significant number of prices in the economy are fixed in the short run (real money is increasing) and firms will produce as many goods and services as are demanded. In the long run, however, money is neutral (real money stays the same because prices are going up), as in the neoclassical model.130 There is also the Austrian School of Economics, which includes different arguments, but most economists fall into either the Keynesian or neoclassical school of thoughts on this issue.

First, the tools for Limited-Reserves framework were: (1) Reserve Requirements $\left({ }_{R}\right)$, (2) Open Market Operations (OMO), (3) Discount Rate $\left({ }^{i_{D R}}\right)$. The ${ }^{i_{F F}}$ is determined by the intersection of supply and demand for reserves. The Fed affects the ${ }^{i_{F F}}$ by using OMO to shift the supply curve left or right. Second, the tools for Ample-Reserves Framework are: (1) Interest paid on Reserves $\left({ }^{i_{I O R}}\right)$, (2) Interest rate paid on Overnight Reverse Repurchase Agreements $\left({ }^{i_{O N R R P}}\right)$, (3) Open Market Operations (OMO), (4) Discount Rate $\left({ }^{i_{D R}}\right)$, (5) Reserves (excess ample reserves, but $r_{R}=0 \%$ ). The supply for reserves intersects the demand for reserves on the flat part of the demand curve. The Fed affects the $i_{F F}$ by raising or lowering the $i_{I O R}$ and the $i_{\text {ON RRP }}$ to shift the flat portion of the demand curve up or down. The FOMC lowers the target iFF range and then, the Fed lowers its administered rates $\left({ }^{i}{ }_{I O R}\right.$ and $i_{O N R R P}$ ). This Fed's “innovation” (paying interest of reserves) has kept the deposit rate closed

\footnotetext{
for you, for the economy, for the country or anything else." At that time, I did not believed him because I was very young. Today, I see that he was absolutely right. See, Kallianiotis (2019b and c, 2020a and c, and 2021a and $b$ ).

${ }^{127}$ European banks are using the pandemic to make changes investors have wanted for years: slash jobs, shut branches and force customers online. See, Patricia Kowsmann and Margot Patrick, "European Banks Use Pandemic to Clean House", February 14, 2021. https://www.wsj.com/articles/european-banks-use-pandemic-toclean-house-11613298601? mod=md usstk news

${ }^{128}$ See, Business Cycles. https://en.wikipedia.org/wiki/Business_cycle

${ }^{129}$ See, Keynesian Economics, https://en.wikipedia.org/wiki/Keynesian economics

${ }^{130} \mathrm{See}$, Neoclassical Economics, https://en.wikipedia.org/wiki/Neoclassical_economics
} 


\section{International Journal of Social Sciences and Management Review}

Volume: 04, Issue: 04 "July - August 2021"

ISSN 2582-0176

to zero $\left({ }^{i_{D}}=0.05 \%\right)$ for twelve years and has discouraged saving and intermediation by riskaverse middle-income people.

The current (dependence on foreigners) state of the economy proved to us that our public policies are inadequate to recover and improve our society from the post first economic crisis of the dreadful 21st century and deficient to relieve us from the second meltdown of the world with the suspicious coronavirus, which caused an unmeasurable healthcare crisis and will cause a global depression worse than the 1929 one.131 We need a monetary and a fiscal policy to cope with this plague, but the benefits of these policies must exceed the costs. The questions still remain and our future is perpetuated invisible and indefinite. The effectiveness and efficiency of monetary policy is very small and social risk is growing; then, the future perspectives are insignificant.

The conclusion is that crises must be prevented,132 if it is possible, and not to be corrected and be reduced or to be diminished, and their responsible creators must be punished. But, in a market oriented economy, which depends on imports (lack of self-sufficiency) this is impossible because the greedy agents try to satisfy their self-interest and not the social one. This self-interest creates different episodes, disturbances, disequilibria, uncertainties, exaggerations, arrogances, greed, fear, unethical business practices, redistributions, inefficiencies, losses of wealth and income, unemployment and lately, fear (intimidation) and control. Public policies (fiscal, trade, and the policy in question here, the monetary) are needed to reduce these problems, to smooth the business cycles and improve the social welfare of the citizens. This latest economic crisis was unique in our economic history, but it is the first of many others that we will see in the near future, like the suspicious current coronavirus (Chinese virus or Wuhan virus or COVID-19)133 one with its destructive health, economic, and social effects.134 Some people call this situation as a global crisis; but, some

${ }^{131}$ Bipartisan House resolution condemns Chinese government over handling of coronavirus response. See, Fox News (3/24/2020). Read the full story

132 See, Kallianiotis (2020c).

${ }^{133}$ It started as a healthcare crisis $=>$ financial crisis $=>$ economic crisis $=>$ human control $=>$ depression $=>$ an anti-Trump tool $=>$ a questionable vaccine $=>$ a very suspicious crisis. The advanced nations must find out who has created this crisis and punish them. Government cannot continue to cave in with the plans of the "economic elites" (dark powers). A group of senior lawmakers from eight democracies including the U.S. have launched a new cross-parliamentary alliance to help counter what they say is the threat China's growing influence poses to global trade, security and human rights.

https://www.bloomberg.com/news/articles/2020-06-05/lawmakers-in-eight-countries-form-new-alliance-tocounter-china

${ }^{134}$ The current coronavirus crisis is a pandemic worse than war. The country is scrambling for necessities because everything is coming from China. Health workers were facing shortages of vital equipment and drugs. This economic crisis will be unmeasurable; the growth of the GDP will be very low. (ABC News, March 18, 2020). The current crisis is actually a new U.S.-China cold war. This combined crisis (healthcare and economic) by the global elites will lead the world to a global depression and will terrorize all people, which is the only way for a global control through fear. See also, "COVID-19 Research Resources", Federal Reserve Bank of St. Luis, https://research.stlouisfed.org/resources/covid-

19/?utm medium=email\&utm campaign $=202003 \mathrm{C} \% 20 \mathrm{Research} \% 20 \mathrm{Newsletter} \& u t m \_$content $=202003 \mathrm{C} \% 20 \mathrm{R}$ esearch\%20Newsletter+CID_807cd9d2ccb00431c4d1f718c446fec6\&utm_source=Research\%20newsletter\&ut m term=COVID-19\%20resources 


\section{International Journal of Social Sciences and Management Review}

Volume: 04, Issue: 04 "July - August 2021"

ISSN 2582-0176

others as divine justice. This is another "benefit" of the inhumane globalization.135 The central bank's policies must be more social than market oriented as they are now. This "independence" of the central banks around the world has caused serious problems to the nations' welfare. The world's problem, today, is that all these institutions and international organization are completely controlled. Then, nothing majestic or inspired is expected from these institutions or by the U.N. What a pity and delusion for the world that had put its hope on them after WWII!

\section{REFERENCES}

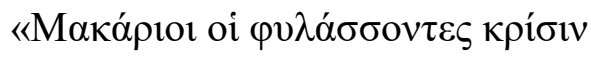

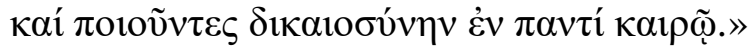
$\Psi \alpha \lambda \mu o ́ \varsigma$ 105, 3

Bank of Canada (2017), "Monetary Policy".

http://www.bankofcanada.ca/core-functions/monetary-policy/

Bernanke, Ben. (2004), "The Great Moderation." Speech given at the annual meetings of the Eastern Economic Association, February 20, 2004. https://www.federalreserve.gov/boarddocs/speeches/2004/20040220/

Bindseil, Ulrich (2016), "Evaluating Monetary Policy Operational Frameworks," in Designing Resilient Monetary Policy Frameworks for the Future. Proceedings of the Federal Reserve Bank of Kansas City Jackson Hole Economic Policy Conference, Jackson Hole, WY, August 25-27, pp. 179-277. https://www.kansascityfed.org/publications/research/escp/symposiums/ /media/6c10f 54077ef4f70ae9214d2ac5dad35.ashx

Bullard, James (2018a), "What Is the Best Strategy for Extending the U.S. Economy's Expansion?", Federal Reserve Bank of St. Louis, September 12, p. 1, https://www.stlouisfed.org/from-the-president/speeches-and-presentations/2018/whatis-best-strategy-extending-expansion

Bullard, James (2018b), "Allan Meltzer and the Search for a Nominal Anchor", Review, Federal Reserve Bank of St. Louis, Vol. 100, No, 2, Second Quarter, pp. 117-126. https://research.stlouisfed.org/publications/review/2018/02/13/allan-meltzer-and-thesearch-for-a-nominal-anchor

Bullard, James (2017), “An Illustrative Calculation of r†.” Federal Reserve Bank of Atlanta 22nd Annual Financial Markets Conference, Amelia Island, FL, May 8.

\footnotetext{
${ }^{135}$ Globalization has caused serious problems to developed countries: (1) Destruction of domestic jobs (increase in unemployment), (2) National security problems, (3) The infant industry protection, (4) The unfair competition from low cost of production countries, (5) Illegal migration, (6) Dilution of indigenous cultures and values, (7) The destruction of the sovereign nation, (8) Contagion from virus coming from under-developing countries, (9) Increase of systemic risk, (10) A war against Christianity and Christians, (11) Re-writing history, (12) Ecumenism (common faith), (13) Global deception, (14) Global control, (15) Global submission of people, (16) Global preparation for the acceptance of the deceiver, (17) Censorship, (18) Reinstatement of the Malthusian Theory on population (reduction of population) and many other suspicious anti-humane means and practices.
} 


\section{International Journal of Social Sciences and Management Review}

Volume: 04, Issue: 04 "July - August 2021"

ISSN 2582-0176

https://www.stlouisfed.org/ /media/Files/PDFs/Bullard/remarks/2017/Bullard_Ameli a_Island_8_May_2017.pdf?la=en.

Caggese, Andrea and Perez-Orive, Ander (2017),. "Capital Misallocation and Secular Stagnation." Finance and Economics Discussion Series 2017-009, Board of Governors of the Federal Reserve System.

Cochrane, John H. (2001), Asset Pricing, Princeton University Press.

Coibion, Oliver and Gorodnichenko, Yuriy (2011), "Monetary Policy, Trend Inflation, and the Great Moderation: An Alternative Interpretation", American Economic Review, 101, February, pp. 341-370

Cooke, Diana A. and Gavin, William T. (2015), "Three Scenarios for Interest Rates in the Transition to Normalcy." Federal Reserve Bank of St. Louis Review, First Quarter, 97(1), pp. 1-24. https://papers.ssrn.com/sol3/papers.cfm?abstract_id=2646132

DeLong, J. Bradford (1997), “America's Peacetime Inflation: The 1970s,” in C. Romer and D.H. Romer (editors), Reducing Inflation: Motivation and Strategy. University of Chicago Press, pp. 247-80.

Engemann, Kristie (2019), “The Fed's Inflation Target: Why 2 Percent?”, Federal Reserve Bank of St. Louis, January 16, pp. 1-5. https://www.stlouisfed.org/openvault/2019/january/fed-inflation-target-2-percent

Firestone, Simon, Amy Lorenc, and Ben Ranish (2019), "An Empirical Economic Assessment of the Costs and Benefits of Bank Capital in the United States", Federal Reserve Bank of St. Louis, REVIEW, pp. 203230.https://files.stlouisfed.org/files/htdocs/publications/review/2019/07/12/anempirical-economic-assessment-of-the-costs-and-benefits-of-bank-capital-in-theunited-states.pdf

Fawley, Brett W. and Neely, Christopher J. (2013), "Four Stories of Quantitative Easing", Federal Reserve Bank of St. Louis Review, January-February, 95(1), pp. 5188.https://research.stlouisfed.org/publications/review/2013/01/04/four-stories-ofquantitative-easing/

Foster, Lucia, Grim, Cheryl, and Haltiwanger, John (2016), "Reallocation in the Great Recession: Cleansing or Not?" in D. Card and A. Mas, organizers, Labor Markets in the Aftermath of the Great Recession. National Bureau of Economic Research, pp. 293-331.

Gagnon, Joseph E. and Sack, Brian (2014), Monetary Policy with Abundant Liquidity: A NewOperating Framework for the Federal Reserve, Peterson Institute for International Economics.

Gavin, William T. (2018), "Monetary Policy Regimes and the Real Interest Rate", Review, Federal Reserve Bank of St. Louis, Vol. 100, No, 2, Second Quarter, pp. 151-169. 


\section{International Journal of Social Sciences and Management Review}

Volume: 04, Issue: 04 "July - August 2021"

ISSN 2582-0176

Gavin, William T., Keen, Benjamin D., Richter, Alexander W., and Throckmorton, Nathaniel A. (2015), "The Zero Lower Bound, the Dual Mandate, and Unconventional Dynamics.” Journal of Economic Dynamics \& Control, 55, pp. 14-38.

Gavin, William T. and Kydland, Finn E. (2000), "The Nominal Facts and the October 1979 Policy Change." Federal Reserve Bank of St. Louis Review, 82(6), pp. 3961.http://citeseerx.ist.psu.edu/viewdoc/summary?doi=10.1.1.196.4648

Gomme, Paul, Ravikumar, B., and Rupert, Peter (2015), "Secular Stagnation and Returns on Capital." Economic Synopses, No. 19, August 18. https://research.stlouisfed.org/publications/economic-synopses/2015/08/18/secularstagnation-and-returns-on-capital/

Gomme, Paul, Ravikumar, B., and Rupert, Peter (2011), "The Return to Capital and the BusinessCycle." Review of Economic Dynamics, 14(2), pp. 262-78. https://ac.elscdn.com/S1094202510000591/1-s2.0-S1094202510000591-main.pdf? tid=24378eb9b6a0-4569-ba72346729689c8b\&acdnat $=1530286243 \_438 b 80 c e e 525 \mathrm{e} 117 \mathrm{~b} 3 \mathrm{c} 07902 \mathrm{e} 3$ $\underline{\mathrm{b} 5 \mathrm{~b} 961}$

Greenspan, Alan (2004), "Risk and Uncertainty in Monetary Policy", American Economic Review, 94 (2), pp. 33-40.

Hadjimichalakis, Michael G. (1982), Monetary Policy and Modern Money Markets, U.S.A.: Lexington Books.

Holston, Kathryn, Laubach, Thomas, and Williams, John C. (2016), "Measuring the Natural Rate of Interest: International Trends and Determinants." Working Paper 2016-11, Federal Reserve Bank of San Francisco, December. https://www.frbsf.org/economicresearch/publications/working-papers/2016/11/

Ihrig, Jane and Scott A. Wolla (2020), “The Fed's New Monetary Policy Tools”, Page One Economics, Economic Research Federal Reserve Bank of St. Louis. https://research.stlouisfed.org/publications/page1-econ/2020/08/03/the-feds-new$\underline{\text { monetary-policy-tools }}$

Kallianiotis, John N. (2021a), "The New Monetary Policy: Its Social Cost and Benefits", Chapter 1, in Progress in Economics Research, Volume 46, Albert Tavidze (Editor), pp. 1-111, Hauppauge, N.Y.: Nova Science Publishers, May 2021, ISBN: 978-153619-704-4 (eBook) and ISBN:

1549-1552. https://novapublishers.com/shop/progress-in-economics-research-volume-46/

Kallianiotis, I.N. (2021b), "Ethics in Finance, Public Policies, and Institutions: The Latest Financial and Social Crises", International Journal of Managerial Studies and Research (IJMSR), Volume 9, Issue 1, pp. 13-41. https://arcjournals.org/internationaljournal-of-managerial-studies-and-research/volume-9-issue-

1/,https://arcjournals.org/pdfs/ijmsr/v9-i1/3.pdf file:///C:/Users/R97719842/Downloads/02200133\%20(2).pdf 


\section{International Journal of Social Sciences and Management Review}

Volume: 04, Issue: 04 "July - August 2021"

ISSN 2582-0176

Kallianiotis, John N. (2020a), "The Two Economic Crises of the 21st Century and the Substitution of Fiscal Policy by Monetary Policy", Chapter 1 in Progress in Economics Research. Volume 45, Albert Tavidze (Editor), pp. 1-91, Hauppauge, N.Y.: Nova Science Publishers, November, ISBN: 978-1-53618-895 (eBook) and ISBN: 1549-1552 https://novapublishers.com/shop/progress-in-economics-researchvolume-45/

Kallianiotis, I.N. (2020b), "Exchange Rate Determination: The Portfolio-Balance Approach", Journal of Applied Finance \& Banking, Vol. 11, Issue 1, October 13, 2020, pp. 19-40. https://www.scienpress.com/journal_focus.asp?Main_Id=56 and https://www.scienpress.com/journal_focus.asp?main_id=56\&Sub_id=IV\&Issue=1969 $\underline{967}$

Kallianiotis, I.N. (2020c), “Can Monetary Policy Prevent Financial Crises?”, International Journal of Economics and Financial Research, Volume 6, Number 4, April, pp. 51-75. https://ideas.repec.org/s/arp/ijefrr.html and https://ideas.repec.org/a/arp/ijefrr/2020p51-75.html

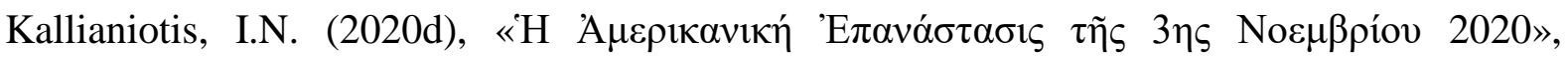

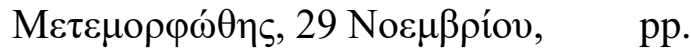
$1-8$. http://metemorfothis.blogspot.com/2020/11/3-2020.html

Kallianiotis, John N. (2019a), Foreign Exchange Rates and International Finance, Hauppauge, N.Y.: Nova Science Publishers, October, ISBN: 978-1-53616-550-0. https://novapublishers.com/shop/foreign-exchange-rates-and-international-finance/

Kallianiotis, I.N. (2019b), "Monetary Policy: Is the Dual Mandate of the Fed Maximizing the Social Welfare?" International Journal of Economics and Financial Research, Vol. 5, No. 6, June, pp. 112-142.https://arpgweb.com/journal/5/archive/06-2019/6/5, https://arpgweb.com/pdf-files/ijefr5(6)112-142.pdf

Kallianiotis, I.N. (2019c), "Monetary Policy, Real Cost of Capital, Financial Markets, and the Real Economic Growth", Journal of Applied Finance \& Banking, Vol. 9, No. 1, pp. $75-118$.

http://www.scienpress.com/journal_focus.asp?main_id=56\&Sub_id=IV\&Issue=8108 15 http://www.scienpress.com/Upload/JAFB/Vol\%209_1_4.pdf

Kallianiotis, John N. (2018), The European Union and its Debt Crises: The Deception of the Greeks, New York: Nova Science Publishers, Inc.

Kallianiotis, John N. (2017a), "Central Banks, Monetary Policy, and their Efficiency", (Chapter 1) in Monetary Policy: Perspectives, Strategies and Challenges, Harriet Ward (editor), New York: Nova Science Publishers.

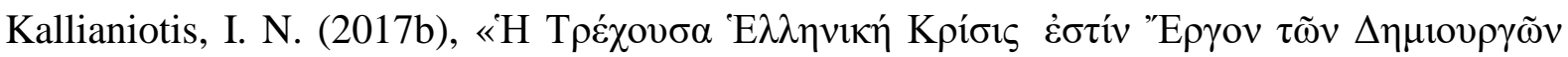

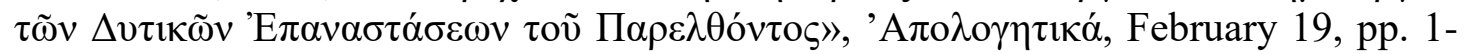
17. http://apologitikaa.blogspot.com.cy/2017/02/i.html 


\section{International Journal of Social Sciences and Management Review}

Volume: 04, Issue: 04 "July - August 2021"

ISSN 2582-0176

Kallianiotis, John N. (2015), “The Latest 'Planned' Financial Crisis, Which Caused the First Depression of the 21st Century, Was a Moral and Political Crisis", in Global Financial Crisis: Causes, Consequences and Impact on Economic Growth, Jeanne Barnett (editor), New York: Nova Publishers, December, Chapter 2, pp. 15-78.

Kallianiotis, John N. (2013), Exchange Rates and International Financial Economics: History,Theories, and Practices, New York: Palgrave Macmillan.

Kallianiotis, I.N. (2004), "Unemployment and Risk Revisited: The Dual Disease of our Socio-Economic System", Journal of Business and Society, Vol. 17, No. 1 \& 2, pp. 46-66.

Kallianiotis, I.N. and Petsas J. (2020), "The Effectiveness of the Single Mandate of the ECB and the Dual of the Fed", Journal of Applied Finance \& Banking, Vol. 10, Issue 4, May $1, \quad$ pp. 115-169. http://www.scienpress.com/journal_focus.asp?main_id=56\&Sub_id=IV\&volid=442 , http://www.scienpress.com/journal_focus.asp?main_id=56\&Sub_id=IV\&Issue=1747 583, http://www.scienpress.com/Upload/JAFB/Vol\%2010_4_11.pdf

Komlos, John (2019a), “The Real U.S. Unemployment Rate is Twice the Official Rate, and the Phillips Curve", https://www.dropbox.com/s/tooigw05ojqlxnv/real\%20unemployment\%20new.pdf?dl $=0$.

Also,https://drive.google.com/file/d/1913Um32spONxL1QgFgPz6VQxPtYt7Ieb/view ?usp=sharing

Komlos, John (2019b), Foundations of Real-World Economics, Second Edition, New York:Routledge. Kwan, Simon (2000), "Margin Requirements as a Policy Tool?", FRBSF Economic Letters,March 24.https://www.frbsf.org/economicresearch/publications/economicletter/2000/march/margin-requirements-as-a-

policytool/ Subscribe RSS Feed Share

Kowsmann, Patricia Close Patricia KowsmannBiography @kowsmann and Margot, Patrick (2021), "European Banks Use Pandemic to Clean House", February 14. https://www.wsj.com/articles/european-banks-use-pandemic-to-clean-house$\underline{11613298601 ? \bmod =\text { md_usstk_news }}$

Lucas, Robert (1976), "Econometric Policy Evaluation: A Critique", In Brunner, K. and Meltzer, A., The Phillips Curve and Labor Markets, Carnegie-Rochester Conference Series on Public Policy, 1, New York: American Elsevier, pp. 19-46.

Mishkin, Frederic S. and Eakins, Stanley G. (2018), Financial Markets and Institutions, Ninth Edition, New York, N.Y.: Pearson.

Nelson, Edward (2005), “The Great Inflation of the Seventies: What Really Happened?” B.E. Journal of Macroeconomics: Advances in Macroeconomics, 5(1), pp. 1-48. 


\section{International Journal of Social Sciences and Management Review}

Volume: 04, Issue: 04 "July - August 2021"

ISSN 2582-0176

Poole, William and Wheelock, David C. (2008), "Stable Prices, Stable Economy: Keeping Inflation in Check Must Be No. 1 Goal of Monetary Policymakers", Federal Reserve Bank of St. Louis, January 1. https://www.stlouisfed.org/publications/regionaleconomist/january-2008/stable-prices-stable-economy-keeping-inflation-in-checkmust-be-no-1-goal-of-monetary-policymakers

Potter, Simon (2017), "Implementing Monetary Policy with the Balance Sheet." Speech at the ECB workshop Money Markets, Monetary Policy Implementation, and Central Bank Balance Sheets, Frankfurt Am Main, Germany, November 6. https://www.bis.org/review/r171106f.pdf

Ross, Stephen A., Westerfield, Randolph W., Jaffe, Jeffrey, and Jordan, Bradford D. (2016), Corporate Finance, 11th edition, New York, N.Y.: McGraw-Hill Education.

Sargent, Thomas J. (2002), "Reactions to the Berkeley Story." October 21, 2002. http://www.tomsargent.com/research/romers3.pdf

Stiglitz, Joseph (2002), Globalization and its discontents, New York: W.W. Norton \& Company.

Stock, James H. and Watson, Mark W. (2003), "Has the Business Cycle Changed and Why?" in M. Gertler and K. Rogoff (editors), NBER Macroeconomics Annual 2002. Volume 17. MIT Press.

Summers, L. H. (2017), "Less is More When It Comes to Federal Reserve Policy." Financial Times, May 7. https://www.ft.com/content/ab77d236-318c-11e7-9555-23ef563ecf9a

Summers, Lawrence H. (2016), "Secular Stagnation and Monetary Policy”, Federal Reserve Bank of St. Louis Review, Second Quarter, 98(2), pp. 93-110. https://research.stlouisfed.org/publications/review/2016/06/17/secular-stagnation-andmonetary-policy/

Taylor, John B. (2013), "Reviewing the "Too Low for Too Long' Evidence." Economics One, October 19. https://economicsone.com/2013/10/19/reviewing-the-too-low-fortoo-long-evidence/

Taylor, John B. (1993). "Discretion versus Policy Rules in Practice". Carnegie-Rochester Conference Series on Public Policy 39, pp. 195-214.

Williams, John C. (2014), "Monetary Policy at the Zero Lower Bound: Putting Theory into Practice." Hutchins Center on Fiscal \& Monetary Policy at Brookings, January 16. https://www.brookings.edu/research/monetary-policy-at-the-zero-lower-boundputting-theory-into-practice/f

Williams, John C. (2017), “The Global Growth Slump: Causes and Consequences.” Federal Reserve Bank of San Francisco Economic Letter, 2017-19, July 3. https://www.frbsf.org/economic-research/publications/economicletter/2017/july/global-growth-slump-causes-consequences-speech/ 


\section{International Journal of Social Sciences and Management Review}

Volume: 04, Issue: 04 "July - August 2021"

ISSN 2582-0176

Williamson, Stephen (2018), "Inflation Control: Do Central Bankers Have it Right?", Review, Federal Reserve Bank of St. Louis, Vol. 100, No. 2, Second Quarter, pp. 127150. https://research.stlouisfed.org/publications/review/2018/04/16/inflation-controldo-central-bankers-have-it-right/

Williamson, Stephen D. (2016a), "Neo-Fisherism: A Radical Idea, or the Most Obvious Solution to the Low-Inflation Problem?", Regional Economist, Federal Reserve Bank of St. Louis, July. https://www.stlouisfed.org/publications/regional-economist/july2016/neo-fisherism-a-radical-idea-or-the-most-obvious-solution-to-the-low-inflationproblem

Williamson, Stephen D. (2016b), "Neo-Fisherian Denial.” New Monetarist (blog), April 14. http://newmonetarism.blogspot.com/

Williamson, Stephen D. (2014), "Monetary Policy in the United States: A Brave New World?" Federal Reserve Bank of St. Louis Review, Second Quarter, 96(2), pp. 11121. https://files.stlouisfed.org/files/htdocs/publications/review/2014/q2/williamson.pdf

Williamson, Stephen D. (2012), "Liquidity, Monetary Policy, and the Financial Crisis: A New Monetarist Approach", American Economic Review, 102(6), pp. 2570-605. https://pubs.aeaweb.org/doi/pdfplus/10.1257/aer.102.6.2570

Woodford, M. (2003), Interest and Prices: Foundations of a Theory of Monetary Policy, Princeton, N.J.: Princeton University Press.

Yellen, Janet (2017), “The Goals of Monetary Policy and How We Pursue Them”. Speech at the Commonwealth Club, San Francisco, CA. https://www.federalreserve.gov/newsevents/speech/yellen20170118a.htm

\section{APPENDIX}

Table A1. Vector Autoregression Estimates, eq. (13), (2008:12-2015:11)

\begin{tabular}{|c|c|c|c|c|c|}
\hline Variables & $d j i a_{t}$ & $r g d p_{t}$ & $i_{10 Y T B_{t}}$ & $p_{t}$ & $u_{t}$ \\
\hline djia $_{t-1}$ & $\begin{array}{l}0.678 * * * \\
(0.119)\end{array}$ & $\begin{array}{l}-0.002 \\
(0.011)\end{array}$ & $\begin{array}{l}0.823 \\
(0.554)\end{array}$ & $\begin{array}{l}0.016 * * \\
(0.008)\end{array}$ & $\begin{array}{l}0.347 \\
(0.357)\end{array}$ \\
\hline djia $_{t-2}$ & $\begin{array}{l}-0.206^{*} \\
(0.117)\end{array}$ & $\begin{array}{l}-0.001 \\
(0.011)\end{array}$ & $\begin{array}{l}-0.640 \\
(0.542)\end{array}$ & $\begin{array}{l}0.001 \\
(0.007)\end{array}$ & $\begin{array}{l}-0.723 * * \\
(0.350)\end{array}$ \\
\hline$r g d p_{t-1}$ & $\begin{array}{l}0.604 \\
(1.305)\end{array}$ & $\begin{array}{l}0.660 * * * \\
(0.119)\end{array}$ & $\begin{array}{l}-5.781 \\
(6.044)\end{array}$ & $\begin{array}{l}-0.034 \\
(0.083)\end{array}$ & $\begin{array}{l}-3.833 \\
(3.895)\end{array}$ \\
\hline$r g d p_{t-2}$ & $\begin{array}{l}1.505 \\
(1.364)\end{array}$ & $\begin{array}{l}0.121 \\
(0.124)\end{array}$ & $\begin{array}{l}11.026^{*} \\
(6.319)\end{array}$ & $\begin{array}{l}-0.038 \\
(0.087)\end{array}$ & $\begin{array}{l}-6.948 * \\
(4.072)\end{array}$ \\
\hline$i_{10 Y T B_{t-1}}$ & $\begin{array}{l}0.021 \\
(0.024)\end{array}$ & $\begin{array}{l}0.002 \\
(0.002)\end{array}$ & $\begin{array}{l}0.990 * * * \\
(0.110)\end{array}$ & $\begin{array}{l}-0.001 \\
(0.002)\end{array}$ & $\begin{array}{l}-0.233 * * * \\
(0.071)\end{array}$ \\
\hline$i_{10 Y T B_{t-2}}$ & -0.005 & -0.002 & $-0.211^{*}$ & -0.001 & $0.176^{* *}$ \\
\hline
\end{tabular}




\section{International Journal of Social Sciences and Management Review}

Volume: 04, Issue: 04 "July - August 2021"

ISSN 2582-0176

\begin{tabular}{|c|c|c|c|c|c|}
\hline & $(0.026)$ & $(0.002)$ & (0.119) & $(0.002)$ & $(0.077)$ \\
\hline$p_{t-1}$ & $\begin{array}{l}-1.393 \\
(1.728)\end{array}$ & $\begin{array}{l}0.096 \\
(0.157)\end{array}$ & $\begin{array}{l}0.891 \\
(8.005)\end{array}$ & $\begin{array}{l}1.074 * * * \\
(0.110)\end{array}$ & $\begin{array}{l}8.692 * \\
(5.158)\end{array}$ \\
\hline$p_{t-2}$ & $\begin{array}{l}1.615 \\
(1.579)\end{array}$ & $\begin{array}{l}-0.023 \\
(0.144)\end{array}$ & $\begin{array}{l}-17.882 * * * \\
(7.315)\end{array}$ & $\begin{array}{l}-0.307 * * * \\
(0.101)\end{array}$ & $\begin{array}{l}-5.925 \\
(4.714)\end{array}$ \\
\hline$u_{t-1}$ & $\begin{array}{l}0.024 \\
(0.035)\end{array}$ & $\begin{array}{l}0.001 \\
(0.003)\end{array}$ & $\begin{array}{l}0.382 * * * \\
(0.163)\end{array}$ & $\begin{array}{l}0.001 \\
(0.002)\end{array}$ & $\begin{array}{l}0.659 * * * \\
(0.105)\end{array}$ \\
\hline$u_{t-2}$ & $\begin{array}{l}0.017 \\
(0.031)\end{array}$ & $\begin{array}{l}0.001 \\
(0.003)\end{array}$ & $\begin{array}{l}-0.260 * \\
(0.146)\end{array}$ & $\begin{array}{l}-0.001 \\
(0.002)\end{array}$ & $\begin{array}{l}0.117 \\
(0.093)\end{array}$ \\
\hline$c_{0}$ & $\begin{array}{l}-21.567 * * \\
(9.876)\end{array}$ & $\begin{array}{l}1.334 \\
(0.899)\end{array}$ & $\begin{array}{l}15.625 \\
(45.755)\end{array}$ & $\begin{array}{l}1.503 * * \\
(0.630)\end{array}$ & $\begin{array}{l}100.804 * * * \\
(29.484)\end{array}$ \\
\hline$i_{F F_{t}}^{e f f}$ & $\begin{array}{l}-0.102 \\
(0.262)\end{array}$ & $\begin{array}{l}0.035 \\
(0.024)\end{array}$ & $\begin{array}{l}-0.989 \\
(1.214)\end{array}$ & $\begin{array}{l}-0.006 \\
(0.017)\end{array}$ & $\begin{array}{l}1.963 * * * \\
(0.782)\end{array}$ \\
\hline$m b_{t}$ & $\begin{array}{l}0.102 \\
(0.178)\end{array}$ & $\begin{array}{l}0.021 \\
(0.016)\end{array}$ & $\begin{array}{l}0.641 \\
(0.826)\end{array}$ & $\begin{array}{l}0.013 \\
(0.011)\end{array}$ & $\begin{array}{l}0.952 * \\
(0.532)\end{array}$ \\
\hline$m_{t}$ & $\begin{array}{l}0.422 \\
(0.419)\end{array}$ & $\begin{array}{l}0.026 \\
(0.038)\end{array}$ & $\begin{array}{l}2.056 \\
(1.943)\end{array}$ & $\begin{array}{l}0.021 \\
(0.027)\end{array}$ & $\begin{array}{l}-1.552 \\
(1.252)\end{array}$ \\
\hline$R^{2}$ & 0.976 & 0.994 & 0.920 & 0.996 & 0.995 \\
\hline SEE & 0.042 & 0.004 & 0.193 & 0.003 & 0.125 \\
\hline$F$ & 218.563 & 807.381 & 61.995 & 1263.581 & 975.740 \\
\hline$N$ & 84 & 84 & 84 & 84 & 84 \\
\hline
\end{tabular}

Note: ${ }^{d j i a_{t}}=\ln$ of U.S. Dow Jones Industrial Average Index, ${ }^{r g d p_{t}}=\ln$ of U.S. real GDP, $i_{10 Y T B_{t}}=$ U.S 10-Year Treasury Bonds Rate, $p_{t}=\ln$ of U.S. CPI, ${ }^{u_{t}}=$ U.S. unemployment rate, $c_{0}=$ constant term, ${ }^{i}{ }_{F F_{t}}^{\text {eff }}=$ U.S. effective federal funds rate, ${ }^{m b_{t}}=\ln$ of U.S. monetary base, ${ }^{m}$ $=\ln$ of U.S. money supply (M2), $* * *=$ significant at the $1 \%$ level, $* *=$ significant at the $5 \%$ level, $*=$ significant at the $10 \%$ level, $R^{2}=\mathrm{R}$-squared, $S E E=\mathrm{S}$.E. equation, $F=$ F-statistic, and $N=$ number of observations.

Source: Economagic.com and Yahoo/Finance. .

Table A2. Vector Autoregression Estimates, eq. (13), (2015:12-2019:06)

\begin{tabular}{|c|c|c|c|c|c|}
\hline Variables & $d j i a_{t}$ & $r g d p_{t}$ & $i_{10 Y T B_{t}}$ & $p_{t}$ & $u_{t}$ \\
\hline \multirow{2}{*}{$\begin{array}{l}\operatorname{djia}_{t-1} \\
0.863^{*}\end{array}$} & $0.539 * * *$ & \multicolumn{2}{|c|}{$0.023 * * *$} & $1.308^{*}$ & $0.014^{*}$ \\
\hline & $(0.175)$ & $(0.010)$ & $(0.793)$ & $(0.009)$ & $(0.568)$ \\
\hline$d j i a_{t-2}$ & $\begin{array}{l}-0.096 \\
(0.209)\end{array}$ & $\begin{array}{l}-0.010 \\
(0.012)\end{array}$ & $\begin{array}{l}-0.676 \\
(0.947)\end{array}$ & $\begin{array}{l}0.012 \\
(0.011)\end{array}$ & $\begin{array}{l}-0.535 \\
(0.678)\end{array}$ \\
\hline$r g d p_{t-1}$ & $\begin{array}{l}-1.495 \\
(2.259)\end{array}$ & $\begin{array}{l}0.004 \\
(0.133)\end{array}$ & $\begin{array}{l}-8.300 \\
(10.232)\end{array}$ & $\begin{array}{c}0.007 \\
(0.116)\end{array}$ & $\begin{array}{l}-5.796 \\
(7.326)\end{array}$ \\
\hline
\end{tabular}




\section{International Journal of Social Sciences and Management Review}

Volume: 04, Issue: 04 "July - August 2021"

ISSN 2582-0176

\begin{tabular}{|c|c|c|c|c|c|}
\hline$r g d p_{t-2}$ & $\begin{array}{l}5.613 * * \\
(2.546)\end{array}$ & $\begin{array}{l}-0.295^{*} \\
(0.150)\end{array}$ & $\begin{array}{l}-12.502 \\
(11.529)\end{array}$ & $\begin{array}{l}0.062 \\
(0.131)\end{array}$ & $\begin{array}{l}8.565 \\
(8.255)\end{array}$ \\
\hline$i_{10 Y T B_{t-1}}$ & $\begin{array}{l}-0.025 \\
(0.042)\end{array}$ & $\begin{array}{l}-0.006^{* *} \\
(0.002)\end{array}$ & $\begin{array}{l}1.043 * * * \\
(0.190)\end{array}$ & $\begin{array}{l}0.004 * * \\
(0.002)\end{array}$ & $\begin{array}{l}0.190 \\
(0.139)\end{array}$ \\
\hline$i_{10 Y T B_{t-2}}$ & $\begin{array}{l}0.059 \\
(0.049)\end{array}$ & $\begin{array}{l}-0.002 \\
(0.003)\end{array}$ & $\begin{array}{l}-0.266 \\
(0.223)\end{array}$ & $\begin{array}{l}-0.005^{* *} \\
(0.003)\end{array}$ & $\begin{array}{l}-0.264 * \\
(0.159)\end{array}$ \\
\hline$p_{t-1}$ & $\begin{array}{l}0.128 \\
(3.933)\end{array}$ & $\begin{array}{l}0.386^{*} \\
(0.232)\end{array}$ & $\begin{array}{l}27.520 \\
(17.814)\end{array}$ & $\begin{array}{l}0.759 * * * \\
(0.203)\end{array}$ & $\begin{array}{l}-10.426 \\
(12.754)\end{array}$ \\
\hline$p_{t-2}$ & $\begin{array}{l}-1.085 \\
(3.439)\end{array}$ & $\begin{array}{l}0.016 \\
(0.203)\end{array}$ & $\begin{array}{l}-15.479 \\
(15.576)\end{array}$ & $\begin{array}{l}-0.239 \\
(0.177)\end{array}$ & $\begin{array}{l}10.432 \\
(11.152)\end{array}$ \\
\hline$u_{t-1}$ & $\begin{array}{l}-0.006 \\
(0.055)\end{array}$ & $\begin{array}{l}0.001 \\
(0.003)\end{array}$ & $\begin{array}{l}-0.082 \\
(0.248)\end{array}$ & $\begin{array}{l}0.004 \\
(0.003)\end{array}$ & $\begin{array}{l}0.463 * * \\
(0.177)\end{array}$ \\
\hline$u_{t-2}$ & $\begin{array}{l}-0.001 \\
(0.052)\end{array}$ & $\begin{array}{l}-0.003 \\
(0.003)\end{array}$ & $\begin{array}{l}0.218 \\
(0.235)\end{array}$ & $\begin{array}{l}-0.001 \\
(0.003)\end{array}$ & $\begin{array}{l}-0.314^{*} \\
(0.168)\end{array}$ \\
\hline$c_{0}$ & $\begin{array}{l}-49.232 * \\
(28.715)\end{array}$ & $\begin{array}{l}9.958 * * * \\
(1.694)\end{array}$ & $\begin{array}{l}117.144 \\
(130.056)\end{array}$ & $\begin{array}{l}1.063 \\
(1.479)\end{array}$ & $\begin{array}{l}6.268 \\
(93.117)\end{array}$ \\
\hline$i_{F F_{t}}^{e f f}$ & $\begin{array}{l}-0.108 \\
(0.091)\end{array}$ & $\begin{array}{l}0.028 * * * \\
(0.005)\end{array}$ & $\begin{array}{l}0.298 \\
(0.412)\end{array}$ & $\begin{array}{l}0.004 \\
(0.005)\end{array}$ & $\begin{array}{l}-0.178 \\
(0.295)\end{array}$ \\
\hline$m b_{t}$ & $\begin{array}{l}0.501 * \\
(0.284)\end{array}$ & $\begin{array}{l}-0.035^{* * *} \\
(0.017)\end{array}$ & $\begin{array}{l}-0.215 \\
(1.285)\end{array}$ & $\begin{array}{l}-0.014 \\
(0.015)\end{array}$ & $\begin{array}{c}0.018 \\
(0.920)\end{array}$ \\
\hline$m_{t}$ & $\begin{array}{l}1.646^{* * * *} \\
(0.681)\end{array}$ & $\begin{array}{l}0.068^{*} \\
(0.040)\end{array}$ & $\begin{array}{c}1.630 \\
(3.083)\end{array}$ & $\begin{array}{l}0.078 * * \\
(0.035)\end{array}$ & $\begin{array}{l}-1.634 \\
(2.208)\end{array}$ \\
\hline$R^{2}$ & 0.973 & 0.997 & 0.934 & 0.997 & 0.969 \\
\hline SEE & 0.031 & 0.002 & 0.139 & 0.002 & 0.099 \\
\hline$F$ & 81.174 & 715.492 & 31.505 & 657.447 & 69.508 \\
\hline$N$ & 43 & 43 & 43 & 43 & 43 \\
\hline
\end{tabular}

Note: See, Table A1.

Source: See, Table A1.

Table A3. Vector Autoregression Estimates, eq. (13), (1995:01-2008:11)

\begin{tabular}{|c|c|c|c|c|c|}
\hline Variables & $d j i a_{t}$ & $r g d p_{t}$ & $i_{10 Y T B_{t}}$ & $p_{t}$ & $u_{t}$ \\
\hline$d_{j i a} a_{t-1}$ & $\begin{array}{l}0.810 * * * \\
(0.087)\end{array}$ & $\begin{array}{l}0.013 \\
(0.009)\end{array}$ & $\begin{array}{l}1.005^{* * * *} \\
(0.419)\end{array}$ & $\begin{array}{l}-9.007 \\
(0.005)\end{array}$ & $\begin{array}{l}-0.012 \\
(0.263)\end{array}$ \\
\hline djia $_{t-2}$ & $\begin{array}{l}0.020 \\
(0.083)\end{array}$ & $\begin{array}{l}-0.005 \\
(0.009)\end{array}$ & $\begin{array}{l}-0.683^{*} \\
(0.401)\end{array}$ & $\begin{array}{l}0.006 \\
(0.005)\end{array}$ & $\begin{array}{l}-0.232 \\
(0.251)\end{array}$ \\
\hline$r g d p_{t-1}$ & $\begin{array}{l}0.293 \\
(0.733)\end{array}$ & $\begin{array}{l}0.642 * * * \\
(0.080)\end{array}$ & $\begin{array}{l}3.905 \\
(3.533)\end{array}$ & $\begin{array}{l}-0.041 \\
(0.044)\end{array}$ & $\begin{array}{l}-4.488 * * \\
(2.212)\end{array}$ \\
\hline
\end{tabular}




\section{International Journal of Social Sciences and Management Review}

Volume: 04, Issue: 04 "July - August 2021"

ISSN 2582-0176

\begin{tabular}{|c|c|c|c|c|c|}
\hline$r g d p_{t-2}$ & $\begin{array}{l}0.383 \\
(0.818)\end{array}$ & $\begin{array}{l}0.331 * * * \\
(0.089)\end{array}$ & $\begin{array}{l}-6.706^{*} \\
(3.944)\end{array}$ & $\begin{array}{l}0.064 \\
(0.049)\end{array}$ & $\begin{array}{l}-2.546 \\
(2.469)\end{array}$ \\
\hline$Y T B_{t-1}$ & $\begin{array}{l}-0.011 \\
(0.016)\end{array}$ & $\begin{array}{l}-0.001 \\
(0.002)\end{array}$ & $\begin{array}{l}1.074 * * * \\
(0.078)\end{array}$ & $\begin{array}{l}0.003 * * * \\
(0.001)\end{array}$ & $\begin{array}{l}-0.001 \\
(0.049)\end{array}$ \\
\hline$i_{10 Y T B_{t-2}}$ & $\begin{array}{l}-0.001 \\
(0.016)\end{array}$ & $\begin{array}{l}-0.001 \\
(0.002)\end{array}$ & $\begin{array}{l}-0.224 * * * \\
(0.078)\end{array}$ & $\begin{array}{l}-0.003 * * * \\
(0.001)\end{array}$ & $\begin{array}{r}0.034 \\
(0.049)\end{array}$ \\
\hline$p_{t-1}$ & $\begin{array}{l}-0.849 \\
(1.207)\end{array}$ & $\begin{array}{l}0.004 \\
(0.132)\end{array}$ & $\begin{array}{l}12.447 * * * \\
(5.819)\end{array}$ & $\begin{array}{l}1.293 * * * \\
(0.073)\end{array}$ & $\begin{array}{l}1.948 \\
(3.643)\end{array}$ \\
\hline$p_{t-2}$ & $\begin{array}{l}0.477 \\
(1.214)\end{array}$ & $\begin{array}{l}-0.104 \\
(0.133)\end{array}$ & $\begin{array}{l}-13.198 * * * \\
(5.853)\end{array}$ & $\begin{array}{l}-0.370 * * * \\
(0.073)\end{array}$ & $\begin{array}{l}1.000 \\
(3.664)\end{array}$ \\
\hline$u_{t-1}$ & $\begin{array}{l}-0.029 \\
(0.027)\end{array}$ & $\begin{array}{l}0.001 \\
(0.003)\end{array}$ & $\begin{array}{l}-0.006 \\
(0.129)\end{array}$ & $\begin{array}{l}0.001 \\
(0.002)\end{array}$ & $\begin{array}{l}0.425 * * * \\
(0.081)\end{array}$ \\
\hline$u_{t-2}$ & $\begin{array}{l}0.001 \\
(0.024)\end{array}$ & $\begin{array}{l}0.001 \\
(0.003)\end{array}$ & $\begin{array}{l}0.038 \\
(0.115)\end{array}$ & $\begin{array}{l}0.001 \\
(0.001)\end{array}$ & $\begin{array}{l}0.169 * * * \\
(0.072)\end{array}$ \\
\hline$c_{0}$ & $\begin{array}{l}-2.172 \\
(0.007)\end{array}$ & $\begin{array}{l}0.273 \\
(0.282)\end{array}$ & $\begin{array}{l}19.066 \\
(12.434)\end{array}$ & $\begin{array}{l}-0.082 \\
(0.156)\end{array}$ & $\begin{array}{l}36.278 * * * \\
(7.784)\end{array}$ \\
\hline$i_{F F_{t}}^{e f f}$ & $\begin{array}{l}-0.001 \\
(0.007)\end{array}$ & $\begin{array}{l}0.001 * \\
(0.001)\end{array}$ & $\begin{array}{l}0.046 \\
(0.033)\end{array}$ & $\begin{array}{l}0.001 \\
(0.001)\end{array}$ & $\begin{array}{l}-0.103 * * * \\
(0.020)\end{array}$ \\
\hline$m b_{t}$ & $\begin{array}{l}-0.156^{*} \\
(0.093)\end{array}$ & $\begin{array}{l}-0.017 * \\
(0.010)\end{array}$ & $\begin{array}{l}0.637 \\
(0.451)\end{array}$ & $\begin{array}{l}-0.035^{* * *} \\
(0.006)\end{array}$ & $\begin{array}{l}0.546 * * \\
(0.282)\end{array}$ \\
\hline$m_{t}$ & $\begin{array}{l}0.058 \\
(0.287)\end{array}$ & $\begin{array}{l}0.061 * * \\
(0.031)\end{array}$ & $\begin{array}{l}0.535 \\
(1.382)\end{array}$ & $\begin{array}{l}0.057 * * * \\
(0.017)\end{array}$ & $\begin{array}{l}1.850 * * \\
(0.865)\end{array}$ \\
\hline$R^{2}$ & 0.980 & 0.999 & 0.960 & 0.999 & 0.964 \\
\hline$S E E$ & 0.042 & 0.005 & 0.203 & 0.003 & 0.127 \\
\hline$F$ & 576.468 & 8924.719 & 283.461 & 21327.73 & 319.582 \\
\hline$N$ & 167 & 167 & 167 & 167 & 167 \\
\hline
\end{tabular}

Note: See, Table A1.

Source: See, Table A1.

Table A4. Vector Autoregression estimates for eq. (14), (2008:12-2015:11)

\begin{tabular}{|c|c|c|c|c|c|}
\hline Variables & $c_{t}$ & $i_{t}$ & $t a_{t}$ & $e_{t}$ & $r g d p_{t}$ \\
\hline$c_{t-1}$ & $\begin{array}{l}0.851 * * * \\
(0.112)\end{array}$ & $\begin{array}{l}0.209 \\
(1.147)\end{array}$ & $\begin{array}{l}0.152 \\
(0.606)\end{array}$ & $\begin{array}{l}1.308 \\
(0.942)\end{array}$ & $\begin{array}{l}0.091 \\
(0.134)\end{array}$ \\
\hline$c_{t-2}$ & $\begin{array}{l}0.009 \\
(0.113)\end{array}$ & $\begin{array}{l}0.461 \\
(1.151)\end{array}$ & $\begin{array}{l}-0.725 \\
(0.608)\end{array}$ & $\begin{array}{l}-0.372 \\
(0.945)\end{array}$ & $\begin{array}{l}0.072 \\
(0.135)\end{array}$ \\
\hline$i_{t-1}$ & $\begin{array}{l}0.003 \\
(0.012)\end{array}$ & $\begin{array}{l}0.826^{* * * *} \\
(0.123)\end{array}$ & $\begin{array}{l}0.003 \\
(0.065)\end{array}$ & $\begin{array}{l}0.111 \\
(0.101)\end{array}$ & $\begin{array}{l}-0.015 \\
(0.014)\end{array}$ \\
\hline$i_{t-2}$ & $\begin{array}{l}-0.021 * \\
(0.012)\end{array}$ & $\begin{array}{l}-0.028 \\
(0.127)\end{array}$ & $\begin{array}{l}0.013 \\
(0.067)\end{array}$ & $\begin{array}{l}0.005 \\
(0.104)\end{array}$ & $\begin{array}{l}0.002 \\
(0.015)\end{array}$ \\
\hline
\end{tabular}




\section{International Journal of Social Sciences and Management Review}

Volume: 04, Issue: 04 "July - August 2021"

ISSN 2582-0176

\begin{tabular}{|c|c|c|c|c|c|}
\hline$t a_{t-1}$ & $\begin{array}{l}-0.047 * * \\
(0.022)\end{array}$ & $\begin{array}{l}-0.021 \\
(0.223)\end{array}$ & $\begin{array}{l}0.160 \\
(0.118)\end{array}$ & $\begin{array}{l}0.265 \\
(0.183)\end{array}$ & $\begin{array}{l}-0.001 \\
(0.026)\end{array}$ \\
\hline$t a_{t-2}$ & $\begin{array}{l}0.046 * * * \\
(0.019)\end{array}$ & $\begin{array}{l}-0.288 \\
(0.191)\end{array}$ & $\begin{array}{l}0.078 \\
(0.101)\end{array}$ & $\begin{array}{l}0.031 \\
(0.157)\end{array}$ & $\begin{array}{l}-0.003 \\
(0.022)\end{array}$ \\
\hline$e_{t-1}$ & $\begin{array}{l}0.034 * * \\
(0.015)\end{array}$ & $\begin{array}{l}-0.178 \\
(0.153)\end{array}$ & $\begin{array}{l}0.099 \\
(0.081)\end{array}$ & $\begin{array}{l}0.661 * * * \\
(0.126)\end{array}$ & $\begin{array}{l}-0.021 \\
(0.018)\end{array}$ \\
\hline$e_{t-2}$ & $\begin{array}{l}-0.023 * \\
(0.014)\end{array}$ & $\begin{array}{l}0.241^{*} \\
(0.140)\end{array}$ & $\begin{array}{l}-0.013 \\
(0.074)\end{array}$ & $\begin{array}{l}-0.063 \\
(0.115)\end{array}$ & $\begin{array}{l}0.003 \\
(0.016)\end{array}$ \\
\hline$r g d p_{t-1}$ & $\begin{array}{l}0.135 \\
(0.105)\end{array}$ & $\begin{array}{l}-1.739 * \\
(1.077)\end{array}$ & $\begin{array}{l}-0.157 \\
(0.569)\end{array}$ & $\begin{array}{l}-1.197 \\
(0.884)\end{array}$ & $\begin{array}{l}0.584 * * * \\
(0.126)\end{array}$ \\
\hline$r g d p_{t-2}$ & $\begin{array}{l}-0.001 \\
(0.114)\end{array}$ & $\begin{array}{l}0.074 \\
(1.166)\end{array}$ & $\begin{array}{l}-0.181 \\
(0.616)\end{array}$ & $\begin{array}{l}-1.004 \\
(0.957)\end{array}$ & $\begin{array}{l}0.001 \\
(0.136)\end{array}$ \\
\hline$c_{0}$ & $\begin{array}{l}-0.480 \\
(0.571)\end{array}$ & $\begin{array}{l}4.984 \\
(5.839)\end{array}$ & $\begin{array}{l}3.167 \\
(3.085)\end{array}$ & $\begin{array}{l}15.599 * * * \\
(4.794)\end{array}$ & $\begin{array}{l}2.193 * * * \\
(0.683)\end{array}$ \\
\hline$i_{F F_{t}}^{e f f}$ & $\begin{array}{l}0.018 \\
(0.018)\end{array}$ & $\begin{array}{l}0.074 \\
(0.185)\end{array}$ & $\begin{array}{l}0.155 \\
(0.098)\end{array}$ & $\begin{array}{l}-0.109 \\
(0.152)\end{array}$ & $\begin{array}{l}0.036 * \\
(0.022)\end{array}$ \\
\hline$m b_{t}$ & $\begin{array}{l}0.006 \\
(0.009)\end{array}$ & $\begin{array}{l}-0.042 \\
(0.095)\end{array}$ & $\begin{array}{l}0.007 \\
(0.50)\end{array}$ & $\begin{array}{l}0.117 \\
(0.078)\end{array}$ & $\begin{array}{l}0.021 * \\
(0.011)\end{array}$ \\
\hline$m_{t}$ & $\begin{array}{l}0.063^{*} \\
(0.035)\end{array}$ & $\begin{array}{l}0.731 * * \\
(0.361)\end{array}$ & $\begin{array}{l}0.549 * * * \\
(0.191)\end{array}$ & $\begin{array}{l}-0.501 * \\
(0.296)\end{array}$ & $\begin{array}{l}0.028 \\
(0.042)\end{array}$ \\
\hline$R^{2}$ & 0.999 & 0.987 & 0.734 & 0.914 & 0.995 \\
\hline SEE & 0.003 & 0.030 & 0.016 & 0.025 & 0.004 \\
\hline$F$ & 4066.438 & 409.314 & 14.826 & 57.207 & 1013.046 \\
\hline$N$ & 84 & 84 & 84 & 84 & 84 \\
\hline
\end{tabular}

Note: ${ }^{c_{t}}=\ln$ of consumption, ${ }^{i}=\ln$ of investment, ${ }^{t a_{t}}=\ln$ of trade account, ${ }^{e_{t}}=\ln$ of spot exchange rate, See also, Table A1.

Source: See, Table A1.

Table A5. Vector Autoregression estimates for eq. (14), (2015:12-2020:12)

$\begin{array}{llllll} & c_{t} & i_{t} & t a_{t} & e_{t} & r g d p_{t} \\ c_{t-1} & 0.631^{* * *} & 0.377^{* * *} & 1.063^{* * *} & 0.357 * * & 0.406^{* * *} \\ & (0.206) & (0.097) & (0.327) & (0.184) & (0.097) \\ c_{t-2} & -0.432^{* *} & 0.343^{* * *} & -1.460^{* * *} & 0.414 * * & 0.318^{* * *} \\ & (0.214) & (0.101) & (0.340) & (0.192) & (0.101) \\ i_{t-1} & 0.507 & 0.849^{* * *} & 0.548 & -0.206 & 0.284 \\ & (0.495) & (0.234) & (0.787) & (0.444) & (0.233) \\ i_{t-2} & -0.920^{* *} & -0.142 & 1.540^{* *} & 0.277 & -0.141 \\ & (0.415) & (0.196) & (0.659) & (0.371) & (0.195) \\ t a_{t-1} & 0.089 & 0.216^{* * *} & 0.200 & 0.048 & 0.106 * *\end{array}$




\section{International Journal of Social Sciences and Management Review}

Volume: 04, Issue: 04 "July - August 2021"

ISSN 2582-0176

\begin{tabular}{|c|c|c|c|c|c|}
\hline & $(0.094)$ & $(0.044)$ & $(0.149)$ & $(0.084)$ & $(0.044)$ \\
\hline$t a_{t-2}$ & $\begin{array}{l}-0.042 \\
(0.108)\end{array}$ & $\begin{array}{l}-0.107 * * \\
(0.051)\end{array}$ & $\begin{array}{l}-0.122 \\
(0.172)\end{array}$ & $\begin{array}{l}0.018 \\
(0.097)\end{array}$ & $\begin{array}{l}-0.047 \\
(0.051)\end{array}$ \\
\hline$e_{t-1}$ & $\begin{array}{l}0.327 * * \\
(0.152)\end{array}$ & $\begin{array}{l}0.131 * \\
(0.072)\end{array}$ & $\begin{array}{l}0.307 \\
(0.241)\end{array}$ & $\begin{array}{l}0.890 * * * \\
(0.136)\end{array}$ & $\begin{array}{l}0.160 * * \\
(0.071)\end{array}$ \\
\hline$e_{t-2}$ & $\begin{array}{l}-0.097 \\
(0.145)\end{array}$ & $\begin{array}{l}0.024 \\
(0.069)\end{array}$ & $\begin{array}{l}-0.092 \\
(0.231)\end{array}$ & $\begin{array}{l}-0.138 \\
(0.130)\end{array}$ & $\begin{array}{l}-0.023 \\
(0.068)\end{array}$ \\
\hline$r g d p_{t-1}$ & $\begin{array}{l}-0.977 * \\
(0.584)\end{array}$ & $\begin{array}{l}-1.364 * * * \\
(0.275)\end{array}$ & $\begin{array}{l}-0.029 \\
(0.926)\end{array}$ & $\begin{array}{l}-0.789 \\
(0.522)\end{array}$ & $\begin{array}{l}-0.826 * * * \\
(0.274)\end{array}$ \\
\hline$r g d p_{t-2}$ & $\begin{array}{l}1.296 * * \\
(0.535)\end{array}$ & $\begin{array}{l}-0.057 \\
(0.253)\end{array}$ & $\begin{array}{l}3.588 * * * \\
(0.850)\end{array}$ & $\begin{array}{l}-0.554 \\
(0.479)\end{array}$ & $\begin{array}{l}-0.084 \\
(0.252)\end{array}$ \\
\hline$c_{0}$ & $\begin{array}{l}4.962 \\
(3.495)\end{array}$ & $\begin{array}{l}8.828 * * * \\
(1.649)\end{array}$ & $\begin{array}{l}-23.474 * * * \\
(5.546)\end{array}$ & $\begin{array}{l}5.202^{*} \\
(3.126)\end{array}$ & $\begin{array}{l}11.612 * * * \\
(1.643)\end{array}$ \\
\hline$i_{F F_{t}}^{e f f}$ & $\begin{array}{l}0.018 \\
(0.011)\end{array}$ & $\begin{array}{l}0.014 * * \\
(0.005)\end{array}$ & $\begin{array}{l}-0.031 * \\
(0.018)\end{array}$ & $\begin{array}{l}0.024 * * \\
(0.010)\end{array}$ & $\begin{array}{l}0.005 \\
(0.005)\end{array}$ \\
\hline$m b_{t}$ & $\begin{array}{l}-0.251 * * * \\
(0.074)\end{array}$ & $\begin{array}{l}-0.082 * * \\
(0.035)\end{array}$ & $\begin{array}{l}0.065 \\
(0.117)\end{array}$ & $\begin{array}{l}0.203 * * * \\
(0.066)\end{array}$ & $\begin{array}{l}-0.108 * * * \\
(0.035)\end{array}$ \\
\hline$m_{t}$ & $\begin{array}{l}0.516 * * * \\
(0.156)\end{array}$ & $\begin{array}{l}0.138 * \\
(0.073)\end{array}$ & $\begin{array}{l}-0.034 \\
(0.247)\end{array}$ & $\begin{array}{l}-0.167 \\
(0.139)\end{array}$ & $\begin{array}{l}-0.003 \\
(0.073)\end{array}$ \\
\hline$R^{2}$ & 0.932 & 0.990 & 0.679 & 0.898 & 0.956 \\
\hline$S E E$ & 0.016 & 0.007 & 0.025 & 0.014 & 0.007 \\
\hline$F$ & 49.824 & 363.828 & 7.6604 & 31.660 & 77.773 \\
\hline$N$ & 61 & 61 & 61 & 61 & 61 \\
\hline
\end{tabular}

Note: See, Tables A1 and A4.

Source: See, Table A1.

Table A6. Vector Autoregression Estimates for eq. (14), (1999:03-2020:12)

$\begin{array}{llllll} & & & & & \\ \text { Variables } & c_{t} & & e_{t} & r g d p_{t} \\ c_{t-1} & 1.254 * * * & 0.455^{* * *} & 0.540^{* * *} & 0.145 & 0.451^{* * *} \\ & (0.072) & (0.135) & (0.145) & (0.154) & (0.045) \\ c_{t-2} & -0.420^{* * *} & -0.505^{* * *} & -0.426^{* * *} & 0.139 & -0.292^{* * *} \\ & (0.083) & (0.156) & (0.168) & (0.179) & (0.052) \\ i_{t-1} & 0.045 & 0.971^{* * *} & -0.036 & 0.091 & 0.029 \\ & (0.038) & (0.072) & (0.077) & (0.082) & (0.024) \\ i_{t-2} & -0.057 & 0.008 & 0.034 & -0.095 & -0.012 \\ & (0.038) & (0.071) & (0.076) & (0.081) & (0.023) \\ t a_{t-1} & -0.056^{*} & 0.052 & 0.646^{* * *} & 0.024 & 0.021 \\ & (0.031) & (0.058) & (0.063) & (0.067) & (0.019) \\ t a_{t-2} & 0.012 & -0.131^{* *} & 0.251^{* * *} & -0.091 & -0.046^{* *} \\ & (0.031) & (0.059) & (0.063) & (0.067) & (0.019)\end{array}$




\section{International Journal of Social Sciences and Management Review}

Volume: 04, Issue: 04 "July - August 2021"

ISSN 2582-0176

\begin{tabular}{|c|c|c|c|c|c|}
\hline$e_{t-1}$ & $\begin{array}{l}0.062 * * \\
(0.029)\end{array}$ & $\begin{array}{l}-0.101 * \\
(0.055)\end{array}$ & $\begin{array}{l}0.007 \\
(0.059)\end{array}$ & $\begin{array}{l}1.143 * * * \\
(0.063)\end{array}$ & $\begin{array}{l}-0.002 \\
(0.018)\end{array}$ \\
\hline$e_{t-2}$ & $\begin{array}{l}-0.043 \\
(0.029)\end{array}$ & $\begin{array}{l}0.106 * \\
(0.054)\end{array}$ & $\begin{array}{l}-0.002 \\
(0.058)\end{array}$ & $\begin{array}{l}-0.195 * * * \\
(0.062)\end{array}$ & $\begin{array}{l}-0.003 \\
(0.018)\end{array}$ \\
\hline$r g d p_{t-1}$ & $\begin{array}{l}-0.548^{* * *} * \\
(0.133)\end{array}$ & $\begin{array}{l}-0.420^{*} \\
(0.250)\end{array}$ & $\begin{array}{l}-0.378 \\
(0.269)\end{array}$ & $\begin{array}{l}-0.689 * * \\
(0.286)\end{array}$ & $\begin{array}{l}0.400 * * * \\
(0.083)\end{array}$ \\
\hline$r g d p_{t-2}$ & $\begin{array}{l}0.700 * * * \\
(0.121)\end{array}$ & $\begin{array}{l}0.408 * \\
(0.229)\end{array}$ & $\begin{array}{l}0.122 \\
(0.246)\end{array}$ & $\begin{array}{l}0.198 \\
(0.262)\end{array}$ & $\begin{array}{l}0.259 * * * \\
(0.076)\end{array}$ \\
\hline$c_{0}$ & $\begin{array}{l}-0.405 \\
(0.581)\end{array}$ & $\begin{array}{l}0.320 \\
(1.097)\end{array}$ & $\begin{array}{l}1.247 \\
(1.177)\end{array}$ & $\begin{array}{l}2.207^{*} \\
(1.252)\end{array}$ & $\begin{array}{l}1.754 * * * \\
(0.361)\end{array}$ \\
\hline$i_{F F_{t}}^{e f f}$ & $\begin{array}{l}0.002 * * \\
(0.001)\end{array}$ & $\begin{array}{l}0.002 * \\
(0.001)\end{array}$ & $\begin{array}{l}0.002 * \\
(0.001)\end{array}$ & $\begin{array}{l}0.001 \\
(0.002)\end{array}$ & $\begin{array}{l}0.001 * * \\
(0.001)\end{array}$ \\
\hline$m b_{t}$ & $\begin{array}{l}0.014 * * * \\
(0.005)\end{array}$ & $\begin{array}{l}0.025^{* * * *} \\
(0.010)\end{array}$ & $\begin{array}{l}0.016 \\
(0.011)\end{array}$ & $\begin{array}{l}-0.005 \\
(0.011)\end{array}$ & $\begin{array}{l}0.004 \\
(0.003)\end{array}$ \\
\hline$m_{t}$ & $\begin{array}{l}0.049 * * * \\
(0.017)\end{array}$ & $\begin{array}{l}0.023 \\
(0.032)\end{array}$ & $\begin{array}{l}0.004 \\
(0.035)\end{array}$ & $\begin{array}{l}-0.003 \\
(0.037)\end{array}$ & $\begin{array}{l}-0.009 \\
(0.011)\end{array}$ \\
\hline$R^{2}$ & 0.998 & 0.995 & 0.942 & 0.973 & 0.997 \\
\hline SEE & 0.011 & 0.021 & 0.022 & 0.024 & 0.007 \\
\hline$F$ & 9920.771 & 3972.536 & 307.203 & 692.399 & 6000.372 \\
\hline$N$ & 262 & 262 & 262 & 262 & 262 \\
\hline
\end{tabular}

Note: See, Tables A1 and A4.

Source: See, Table A1. 